\title{
HYDROGEOLOGY OF THE BUFFALO AQUIFER, CLAY AND WILKIN COUNTIES, WEST-CENTRAL MINNESOTA
}

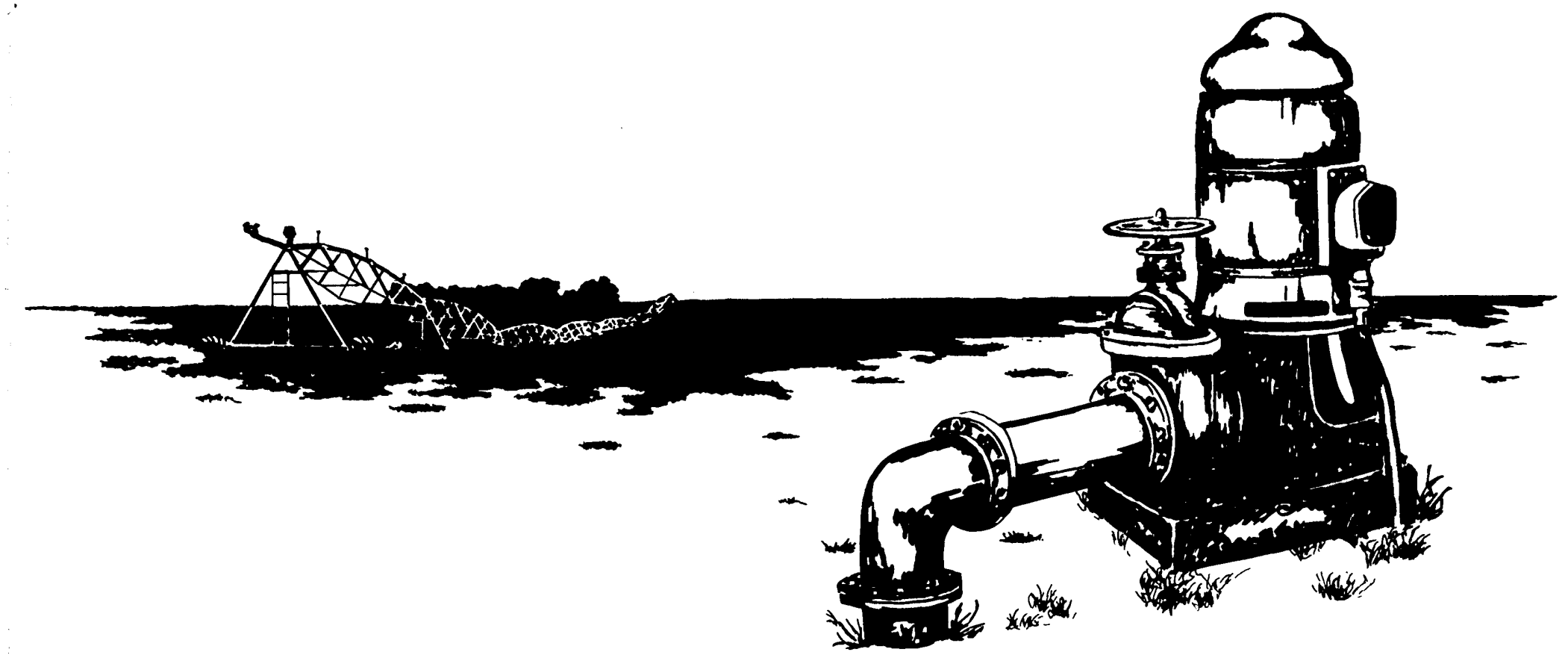

U. S. GEOLOGICAL SURVEY

WATER -RESOURCES INVESTIGATIONS 81-4

PREPARED IN COOPERATION WITH THE

MINNESOTA DEPARTMENT OF NATURAL RESOURCES

CLAY AND WILKIN COUNTIES

CITIES OF MOORHEAD AND SABIN

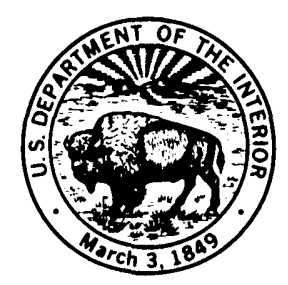




\begin{tabular}{|c|c|}
\hline REPORT DOCUMENTATION & 1. REPORT NO. \\
PAGE & \\
\hline
\end{tabular}

4. Title and Subtitle

HYDROGEOLOGY OF THE BUFFALO AQUIFER, CLAY AND WILKIN COUNTIES, WEST-CENTRAL MINNESOTA

7. Author(s)

Ronald J. Wolf

9. Performing Organization Name and Address

U.S. Geological Survey

Water Resources Division

702 Post Office Building

St. Paul, Minnesota 55101

12. Sponsoring Organization Name and Address

U.S. Geological Survey

Water Resources Division

702 Post office Building

St. Paul, Minnesota 55101

15. Supplementary Notes

Prepared in cooperation with the Minnesota Department of Natural Resources, Clay and Wilkin Counties, and the cities of Moorhead and Sabin

16. Abstract (Limit: 200 words)

The Buffalo aquifer is the principal source of ground-water supplies in the Moorhead, Minnesota area. The aquifer is an elongate, narrow deposit of sand and gravel, which locally contains water under confined conditions. Although the Buffalo aquifer contains about 270 billion gallons of water in storage, only 120 billion gallons could be withdrawn. Largest well yields occur along the deep trough in the center of the aquifer. Induced streambed infiltration may be possible in certain areas where the stream overlies the aquifer and where the intervening lake sediments are thin or absent. Construction of a numerical model for aquifer evaluation has shown that a considerable amount of ground water is discharged through the confining bed to the stream or leaves the area as underflow to the west. Water from the Buffalo aquifer generally is very hard and of the calcium bicarbonate type. The average discharge of the Buffalo River for the base period 1946-78 ranges from 0.229 cubic foot per second per square mile near Hawley to 0.108 cubic foot per second per square mile at Sabin. Surface water in the Buffalo River drainage system is dominantly a calcium bicarbonate type similar to ground water, especially at low flow in the upper reaches of the tributaries.

17. Document Analysis a. Descriptors

*Hydrogeology, *Groundwater supplies, *Hydraulic conductivity, *Infiltration, Numerical model

b. Identifiers/Open-Ended Terms

*Buffalo River, *Buffalo aquifer, *Minnesota,

c. COSATI Field/Group

18. Availability Statement

No restriction on distribution

\begin{tabular}{|l|l|}
\hline 19. Security Class (This Report) & $\begin{array}{c}\text { 21. No. of Pages } \\
89\end{array}$ \\
\hline 20. Security Class (This Page) & 22. Price \\
\hline
\end{tabular}


HYDROGEOLOGY OF THE BUFFALO AQUIFER,

CLAY AND WILKIN COUNTIES,

WEST-CENTRAL MINNESOTA

By R. J. Wolf

U.S. GFOLOGICAL SURVEY

Water-Resources Investigations $81-4$

Prepared in cooperation with the

MINNFSOTA DEPARTMENT OF NATURAL RESOURCES,

CLAY AND WILKIN COUNTIES, AND THE

CITIES OF MOORHEAD AND SABIN

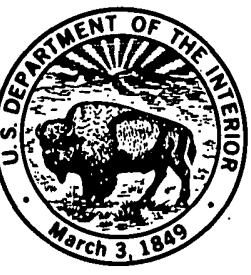


UNITED STATES DEPARTMENT OF THE INTERIOR

CECIL B. ANDRUS, Secretary

GEOLOGICAL SURVEY

H. William Menard, Director

For additional information write to:

U.S. Geological Survey

702 Post Office Building

St. Paul, Minnesota 55101 


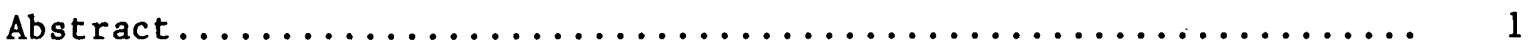

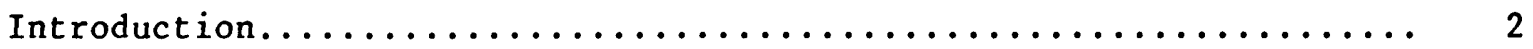

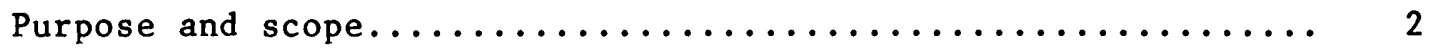

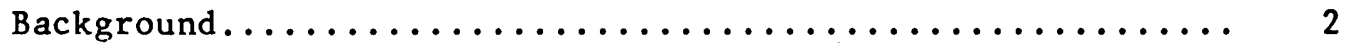

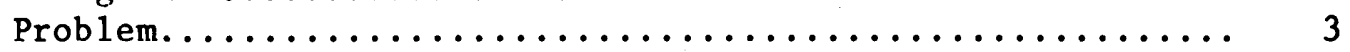

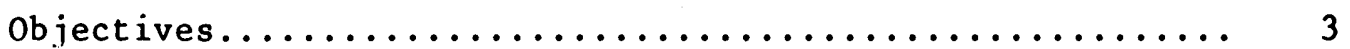

Location and extent.............................. 4

Previous investigations.......................... 4

Methods of investigation.......................... 4

Test-hole numbering system........................ 6

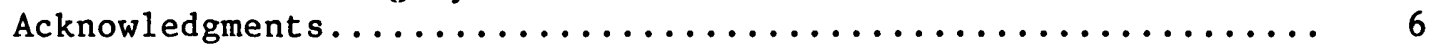

Physical setting.................................

Physiography and geographic setting.................. 6

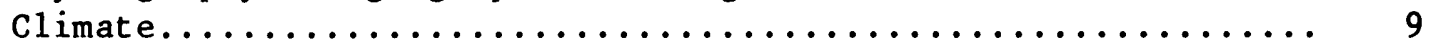

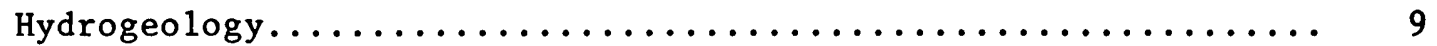

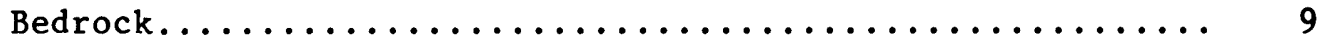

Drift ................................. 11

Buried aquifers............................. 11

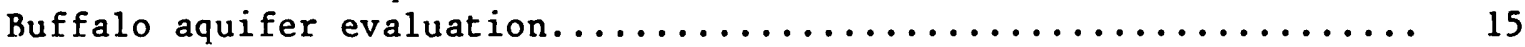

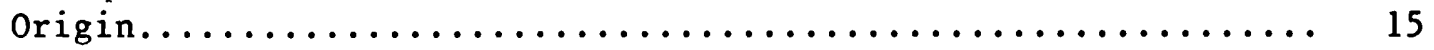

Physical characteristics.......................... 22

Thickness of overlying confining bed.................... 22

Hydraulic characteristics........................... 22

Ground-water movement .......................... 38

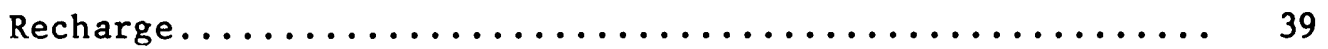

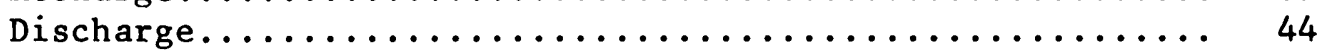

Ground-water surface-water relationships ................. 44

Ground-water availability.......................... 49

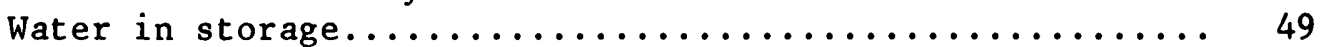

Theoretical maximum well yields................. 49

Induced infiltration........................ 50

Artificial recharge........................ 51

Numerical model for aquifer evaluation................. 51

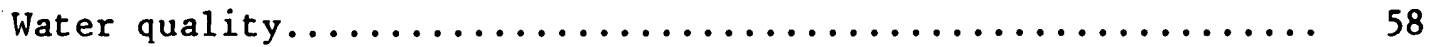

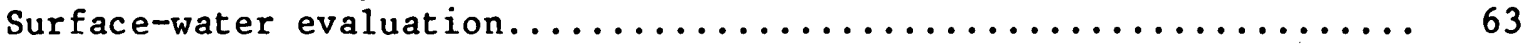

Streamflow characteristics......................... 63

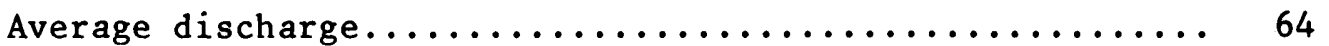

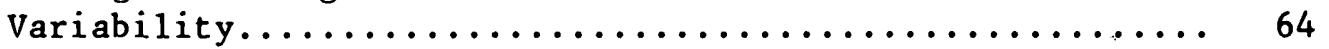

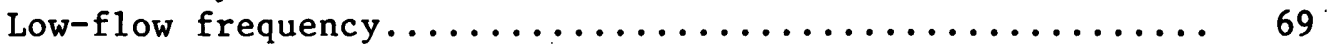

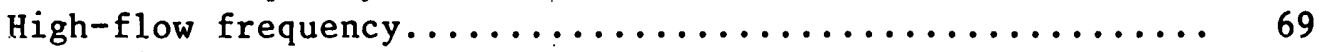

Fluvial sediment ................................. 74

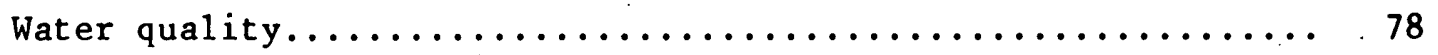

Summary.......................................... 78

References....................................... 81 


\section{ILLUSTRATIONS}

Page

Figure 1. Map showing location, extent, and tributaries

of the Buffalo River watershed, Minnesota............

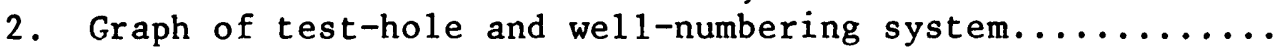

3. Map showing physiographic divisions of the Buffalo River watershed and trace of the hydrogeologic sections of the

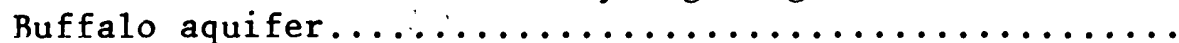

4. Graph of cumulative departure of monthly total precipitation at Fargo and Wahpeton, N. Dak., for the 1977-78 water years from the 1941-70 normal monthly

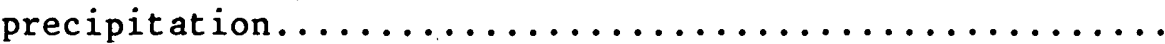

5. Map of possible depth to Precambrian bedrock based on

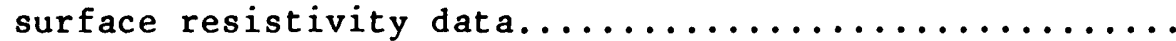

6. Map of known extent of buried aquifer zones in western part of Buffalo River watershed................ 14

7. Map of configuration of the top of the Buffalo aquifer... 16

8. Map of saturated thickness of the Buffalo aquifer....... 18

9. Map of configuration of the till surface underlying the Buffalo aquifer........................... 20

10-15. Hydrogeologic sections:

10. $A-A^{\prime}$ northeast of Moorhead............... 23

11. B-B' northeast of Moorhead................ 24

12. $C-C^{\prime}$ northeast of Moorhead................. 25

13. D-D' southeast of Moorhead and north of Sabin... 26

14. E-E' south of Sabin and west of Barnesville.... 27

15. $F-F^{\prime}$ and $G-G^{\prime}$ northeast and east of Wolverton... 28

16. Map of thickness of lake sediments overlying the Buffalo

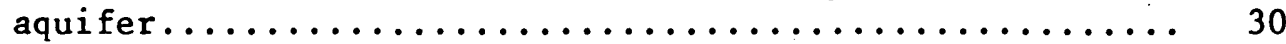

17. Map of hydraulic conductivity of the Buffalo aquifer.... 32

18. Map of transmissivity of the Buffalo aquifer.......... 34

19. Map showing the theoretical maximum short-term yields to

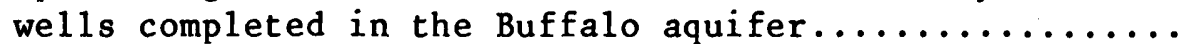

20. Map showing location of measuring sites and altitudes of water levels in the Buffalo aquifer, overlying confining layer, and nearby streams, September $17,1978 \ldots \ldots \ldots \ldots$.

21. Hydrographs showing contrasting patterns of water-level fluctuations in water table and confined areas of the

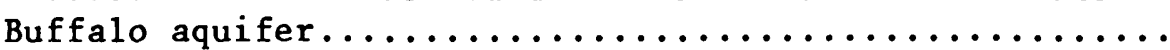

22. Hydrograph showing method used to determine annual

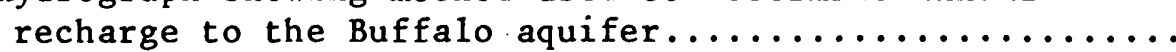

23. Hydrograph showing response of water level in the Buffalo aquifer to pumpage from Moorhead city well field.......

24. Graphs comparing the potentiometric profile of the Buffalo aquifer with stream profile and flow of the

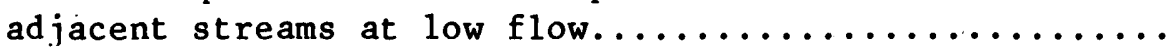


Figure 25. Graphs showing flow of the South Branch Buffalo River and Buffalo River, April 18-20, 1977, and November

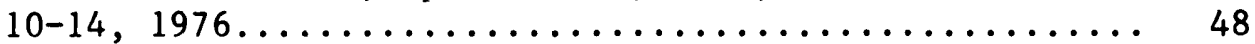

26. Graphs showing sediment-transport curves for sediment stations in the Buffalo River watershed............ 52

27. Graphs showing mean monthly temperature of the South Branch Buffalo River at Sabin and the Buffalo River

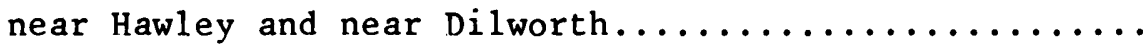

28. Graph showing relationship of specific conductance, streamflow, and precipitation 1977-78, Buffalo River

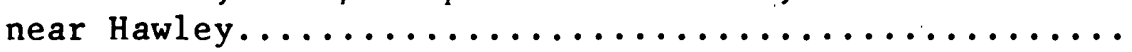

29. Graph showing relationship of specific conductance, streamflow, and precipitation 1977-78, South Branch Buffalo River at Sabin.................... 55

30. Graph showing relationship of specific conductance, streamflow, and precipitation 1977-78, Buffalo River

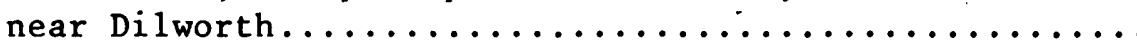

Diagram showing the suitability of water from the Buffalo aquifer and water from nearby streams for irrigation in terms of sodium-adsorption-ratio and

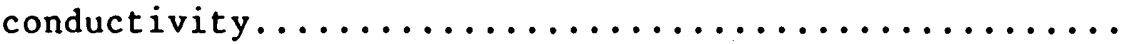

32. Map showing ground-water-quality sampling sites in the

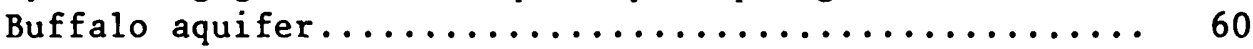

33. Map showing location and type of surface-water-datacollection sites in the Buffalo River watershed.......

34. Graph showing the mean monthly discharge at the Buffalo River watershed gaging stations for the

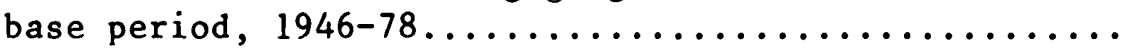

35. Duration curves for gaged streams in the Buffalo River watershed......................... 68

36. Duration hydrograph of mean monthly discharge for the Buffalo River near Dilworth................ 70

37. Low-flow frequency curves for gaged streams in the Buffalo River watershed and a graph showing the number of consecutive days of no flow for South Branch Buffalo River at Sabin.................. 71

38. High-flow frequency curves at the three Buffalo River watershed gaging stations................... 72

39. Map showing surface-water-quality sampling sites in

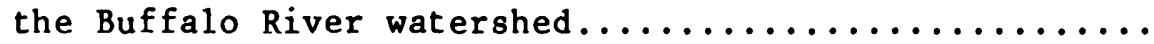


Table 1. Comparison of water quality in the Buffalo

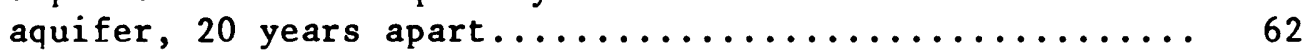

2. Station name, number, drainage area, period of record, discharge, annual runoff, and low-flow frequency at surface-water-data-collection sites, Buffalo River

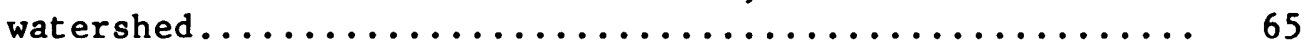

3. Distribution of flood peaks by months for streams in

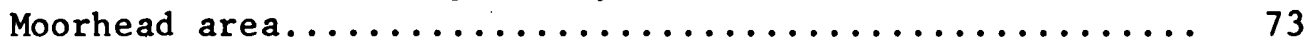

4. Sediment-sampling sites in the Buffalo River watershed and length of record................................ 74

5. Estimated average suspended-sediment discharge at Buffalo River watershed stations......................... 76

6. Comparison of surface-water quality at low and high flows. 77

CONVERSION FACTORS

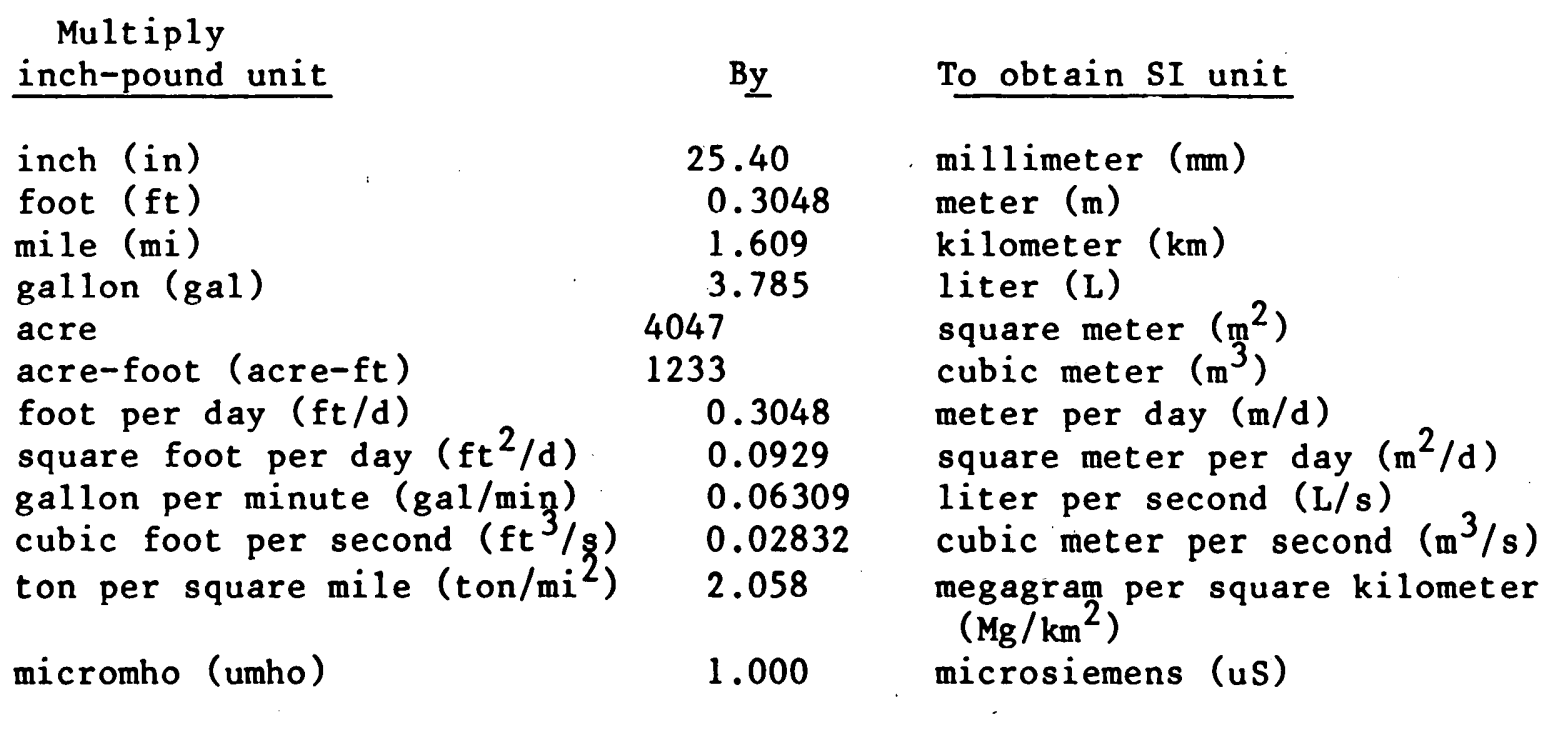

National Geodetic Vertical Datum of 1929 (NGVD of 1929).

A geodetic datum derived from a general adjustment of the first order level nets of both the United States and Canada, formerly called "mean sea level". The datum was derived from the average sea level over a period of many years at 26 tide stations along the Atlantic, Gulf of Mexico, and Pacific Coasts. 
HYDROGEOLOGY OF THE BUFFALO AQUIFER,

CLAY AND WILKIN COUNTIES,

WEST-CENTRAL MINNESOTA

By R. J. Wolf

\begin{abstract}
Increasing demands on the water resources near Moorhead, Minnesota, have led to conflicting opinions on the availability and quality of water. Results of this study indicate that large water supplies are available in the western part of the Buffalo River watershed. The Precambrian bedrock surface, which ranges in depth from 200 to 1,000 feet below land surface, forms the lower boundary of ground-water supplies. Above this boundary, several aquifers are generally present in the drift and possibly in sandstone of Cretaceous age. Some wells in the deeper aquifers may have initial yields of 1,000 gallons per minute, but these yields cannot generally be sustained for periods of several months or longer.

The Buffalo aquifer is the principal source of ground-water supplies in the area. The aquifer is an elongate deposit of sand and gravel that locally contains water under confined conditions. Lake sediments overlie more than half the aquifer and are 20 to 120 feet thick. Its most permeable part is a deep, narrow trough along the axis of the 32-mile long aquifer. The average hydraulic conductivity ranges from about 20 feet per day along the outer edges to about 300 feet per day along the axis. Its saturated thickness ranges from 0 at the edges to about 200 feet in the center. The general direction of flow is northward and toward the adjacent stream. Seepage runs along the South Branch Buffalo River indicate the river loses water near the Moorhead well field and in a 22-mile reach upstream from Sabin.

Although the Buffalo aquifer contains about 270 billion gallons of water in storage, only about 120 billion gallons could be withdrawn. Well yields are greatest along the narrow, deep trough along the axis of the aquifer. Induced streambed infiltration is possible in certain areas where the stream overlies the aquifer, if the intervening lake sediments are thin or absent. The aquifer could be artificially recharged through properly constructed and maintained recharge ponds where it is most permeable and most storage space is available.
\end{abstract}


A numerical model designed for aquifer evaluation has shown that a considerable amount of ground water is discharged through the confining bed to the stream or leaves the area as underflow to the west. The model indicates the need for more data on (1) vertical hydraulic conductivity, head, and thickness of the confining bed; (2) head differences between the aquifer, confining beds and the stream; and (3) long-term water levels, recharge, and pumpage.

Water from the Buffalo aquifer is generally very hard and of the calcium bicarbonate type. Dissolved solids range from about 300 to 1,900 milligrams per liter. The water is well suited for municipal supplies except for hardness and, in some places, high concentrations of iron and sulfate. The water is well suited for irrigation in terms of low sodium hazard and low concentrations of boron.

The average discharge of the Buffalo River during the base period 194678 ranged from 0.229 cubic foot per second per square mile near Hawley to 0.108 cubic foot per second per square mile at Sabin. Flow-duration and low-flow-frequency curves indicate a persistent low flow for the Buffalo River near Hawley and long periods of low or no flow for the South Branch Buffalo River at Sabin. Approximately 90 percent of the flood peaks on the Buffalo River system occur from March through July, with the greatest number of peaks in April. Estimated average sediment yields of the Buffalo River near Hawley and near Dilworth and of the South Branch Buffalo River at Sabin are $14.2,9.7$, and 3.9 tons per square mile per year, respectively.

Surface water in the Buffalo River drainage system is a calcium bicarbonate type similar to the water in the Buffalo aquifer, especially at low flow in the upper reaches of the tributaries. The Buffalo River generally contains lower concentrations of dissolved solids and of specific ions (except sodium and chloride) than the South Branch Buffalo River. Mean monthly stream temperatures range from $0^{\circ}$ to $23^{\circ}$ Celsius.

\section{INTRODUCTION}

Purpose and Scope

Background

Increasing demands for water in the Red River of the North valley for agricultural, industrial, and municipal uses have led to concern and conflicting opinions on water availability and quality, particularly in the Moorhead area in the Buffalo River watershed. State and local officials have requested the U.S. Geological Survey to evaluate the water resources in a part of the watershed near Moorhead to assist development of an areawide water-management plan. 


\section{Problem}

Before 1978, the city of Moorhead had a State permit for annual withdrawals of 4,500 acre-feet (4.02 Mgal/d) from combined surface-water and ground-water sources. Increased appropriations to 7,090 acre-feet annually ( $6.33 \mathrm{Mgal} / \mathrm{d}$ ) were requested in 1977 by the city and approved by the State in 1978. Future water withdrawals by the city are estimated to be as high as 9,413 acre-feet or $8.4 \mathrm{Mgal} / \mathrm{d}$.

Several studies were made concerning water supply for the city, but none have adequately considered the effects that large withdrawals will have on the hydrologic system. Although schemes for assuring perennial maximum water availability include artificial recharge to the Buffalo aquifer, water quality and streamflow have not been defined adequately. Much geologic and hydrologic data are also available on the Buffalo aquifer, but its hydrologic parameters, geometry, and boundary conditions are not well enough defined to use simulation modeling effectively for water management. Because of the complexity of the aquifer system, it is doubtful that prediction of the effects on water levels and water quality caused by pumping or recharging the aquifer can be made without simulation analysis.

The city of Moorhead has searched for solutions to growing water-supply needs. Declining water levels in the deep city wells completed in buried aquifers prompted Moorhead, in the late 1940's, to obtain new supplies from the partly. confined Buffalo aquifer 5 miles to the east along the South Branch Buffalo River. In the early 1960 's, declining water levels, uncertain estimates of potential maximum sustained yield, and an increase in mineralization of water from the Buffalo aquifer further prompted the city to turn to the Red River as its primary source of supply. Some recovery of water levels in the Buffalo aquifer and deeper aquifers resulted from the decreased pumping of ground water. Increasing demands for water in the 1970 's has led the city to look for an assured water supply by combined use of water from the Red River of the North, the Buffalo River, and the Buffalo aquifer.

\section{Objectives}

The objectives of this study are to (1) determine the areal extent and thickness of the Buffalo aquifer and the general occurrence of deeply buried aquifers, (2) determine the potential for development of water supplies from wells in the Buffalo aquifer, (3) investigate and discuss annual recharge to the Buffalo aquifer and the potential for artificially recharging the aquifer, (4) determine the chemical quality of water in the aquifer and in area streams, (5) establish a network of observation wells for monitoring water levels and water quality in the aquifer, (6) determine the relationship between the aquifer and the adjacent streams, and (7) update information on the flow characteristics of streams. The main focus of this study is on water in the Buffalo aquifer and on flow characteristics of streams. 
Location and Extent

The study area is in northwestern Minnesota in the western part of the Buffalo River watershed (fig. 1). The Buffalo aquifer trends north-south about 5 miles east of Moorhead and has been traced along Clay County Road 11 from 7 miles north of U.S. Highway 10 to 8 miles south of the Clay-Wilkin county line. The aquifer is 32 miles long, ranges from 1 to 8 miles wide, and is about 200 feet thick along its axis. Streams include the Red River of the North, the Buffalo River, and the South Branch Buffalo River.

\section{Previous Investigations}

Early descriptions of geology were presented by Winchell and Upham (1888) and Winchell and others (1899). The Quaternary geology of the Red River valley was described by Upham (1895). Hall and Willard (1905) investigated the general geology of the Fargo-Moorhead area. General descriptions of the geology and ground water were included in a report by Allison (1932). Glacial geology was discussed by Leverett (1932), Wright (1962), and Wright and Ruhe (1965). A reconnaissance of the soils of the Red River valley was completed by Nikiforoff and others (1939). Byers and others (1946) made an intensive investigation of ground-water conditions in and around Fargo.

The first detailed information on the Buffalo aquifer was presented by U.S. Geological Survey press releases in May and July 1947. Dennis and others (1949) reported on the geology and ground water of Cass County, N. Dak., and Clay County, Minn. A report to the city of Moorhead by Meyer (1955) includes the results of pumping tests of the Buffalo aquifer in August and September 1955. The Buffalo aquifer (called the East Dilworth aquifer) was described in detail by Guyton and Associates (1957). Bingham (1960) provided geologic and ground-water data for Clay County, Minn. Maclay and Winter (1967) discussed geochemistry and ground-water movement in northwestern Minnesota. The water resources of the Buffalo River watershed were described by Maclay and others (1969). Maclay and others (1972) discussed the water resources of the Red River of the North in Minnesota. Physical-data maps for land-use planning in Cass County, N. Dak. and Clay County, Minn. were prepared by Arndt and Moran (1974). Various schemes for water-resources development in the Buffalo River watershed were discussed by Barr Engineering Inc. (1975).

\section{Methods of Investigation}

Data for this project were collected and analyzed from October 1976 to September 1979. Field work included extensive surface electricalresistivity surveys, drilling of 87 power-auger holes and 6 hydraulicrotary test holes, installation of 35 observation wells, 3 aquifer tests, sampling of water from 20 wells and 9 stream sites for water-quality analyses, core sampling for determining vertical hydraulic-conductivity, periodic water-level measurements in wells and streams, and streamflow 


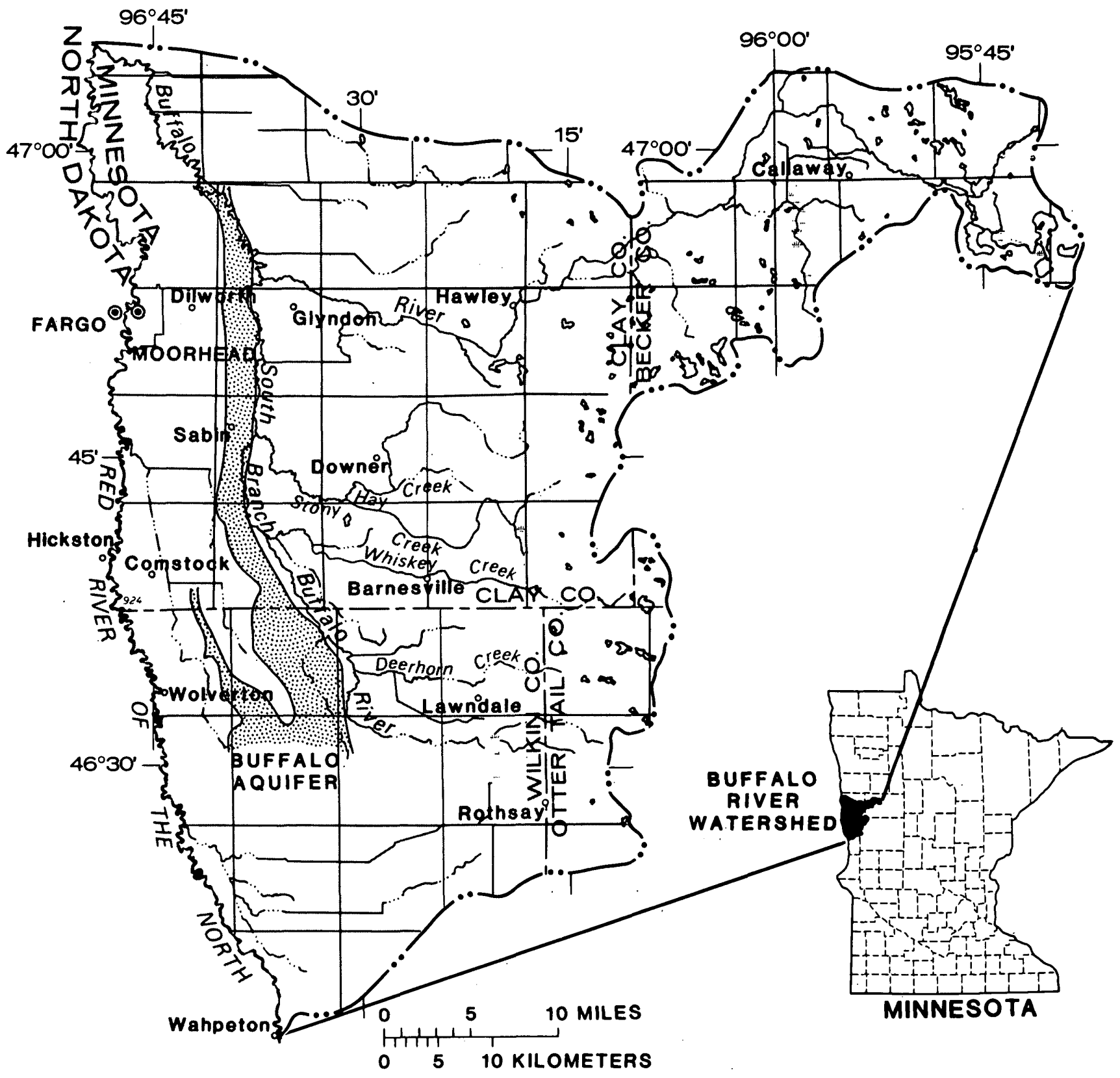

FIgure 1.--Location, extent, and tributarles of the Buffalo RIver watershed, MInnesota 
measurements. Data compiled from previous investigations included water-quality analyses, surface-water data, and well and test-hole logs. Laboratory measurements included chemical analyses of 20 ground-water samples and 18 surface-water samples, analysis of daily fluvial suspendedsediment samples, and falling-head hydraulic-conductivity determinations of 5 core samples of the confining bed. These data and information from previous reports and the files of the U.S. Geological Survey and the Minnesota Department of Natural Resources were used in describing the hydrology. Numerical modeling was used to (1) refine a conceptual model of the Buffalo aquifer, and (2) identify the kinds and location of additional information needed for quantitative evaluation of aquifer response to projected stresses.

Test-hole Numbering System

The system of numbering test holes and wells used in this report is based on the U.S. Bureau of Land Management's system of subdivision of the public lands. The Buffalo River watershed is in the fifth principal meridian and base line subdivision. The first segment of a well or test-hole number indicates the township north of the base line; the second, the range west of the principal meridian; and the third, the section in which the well or test hole is situated. The letters A, B, C, and D, following the section number, locate the well within the section. The first letter denotes the 160-acre tract or quarter section, the second denotes the 40-acre tract, and the third denotes the 10-acre tract. The letters are assigned in a counterclockwise direction beginning in the northeast quarter section. Successive well numbers beginning with 1 are added as suffixes to distinguish wells within a given 10-acre tract. Figure 2 illustrates the method of numbering. For example, the number 140.47.19CDDl signifies the first well or test hole located in the $\mathrm{SE}^{1} / 4 \mathrm{SE}^{1} / 4 \mathrm{SW}^{1} / 4 \mathrm{sec} .19, \mathrm{~T}$. 140 N., R. 47 W.

\section{Acknowledgments}

The author is grateful for information provided by property owners and well drillers. Special gratitude is extended to those who permitted test drilling on their land and to irrigators who permitted use of their wells and equipment for collection of water samples, measurement of water levels, and aquifer testing.

\section{PHYSICAL SETTING}

Physiography and Geographic Setting

The Buffalo River watershed includes two main physiographic areas - a glacial lake plain and a glacial moraine. The two areas, shown on figure 3 , offer sharp physical, cultural, and economic contrasts. 


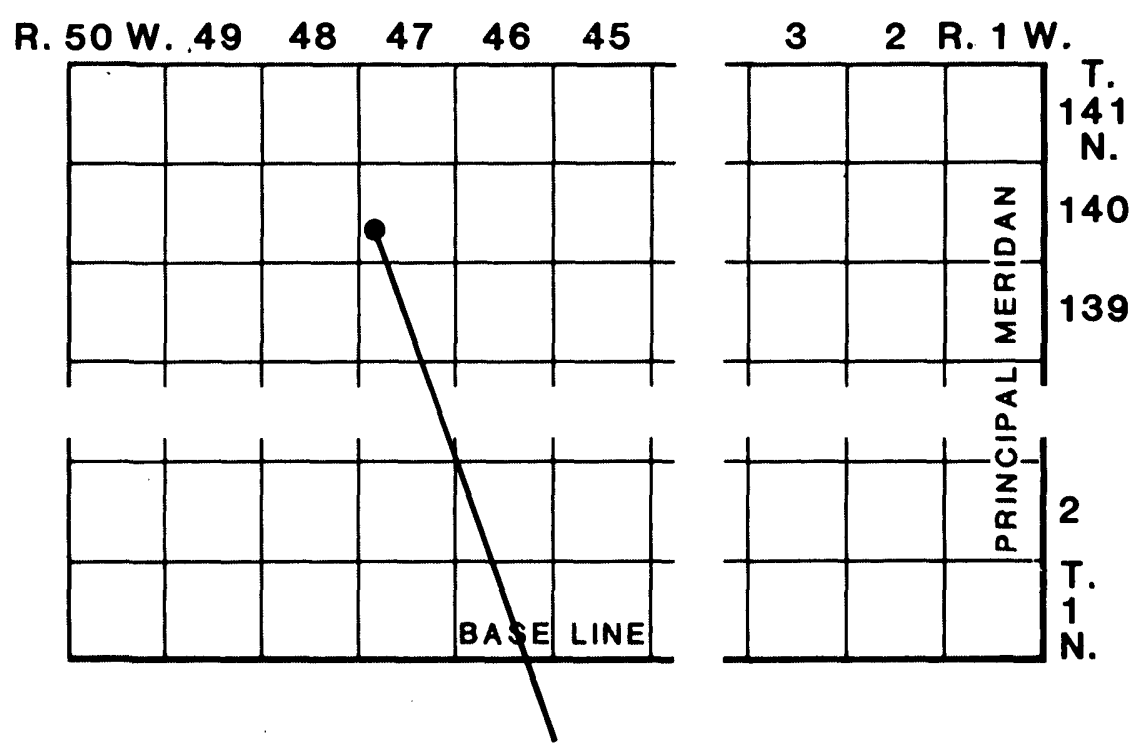

WELL 140.47.19CDD1.

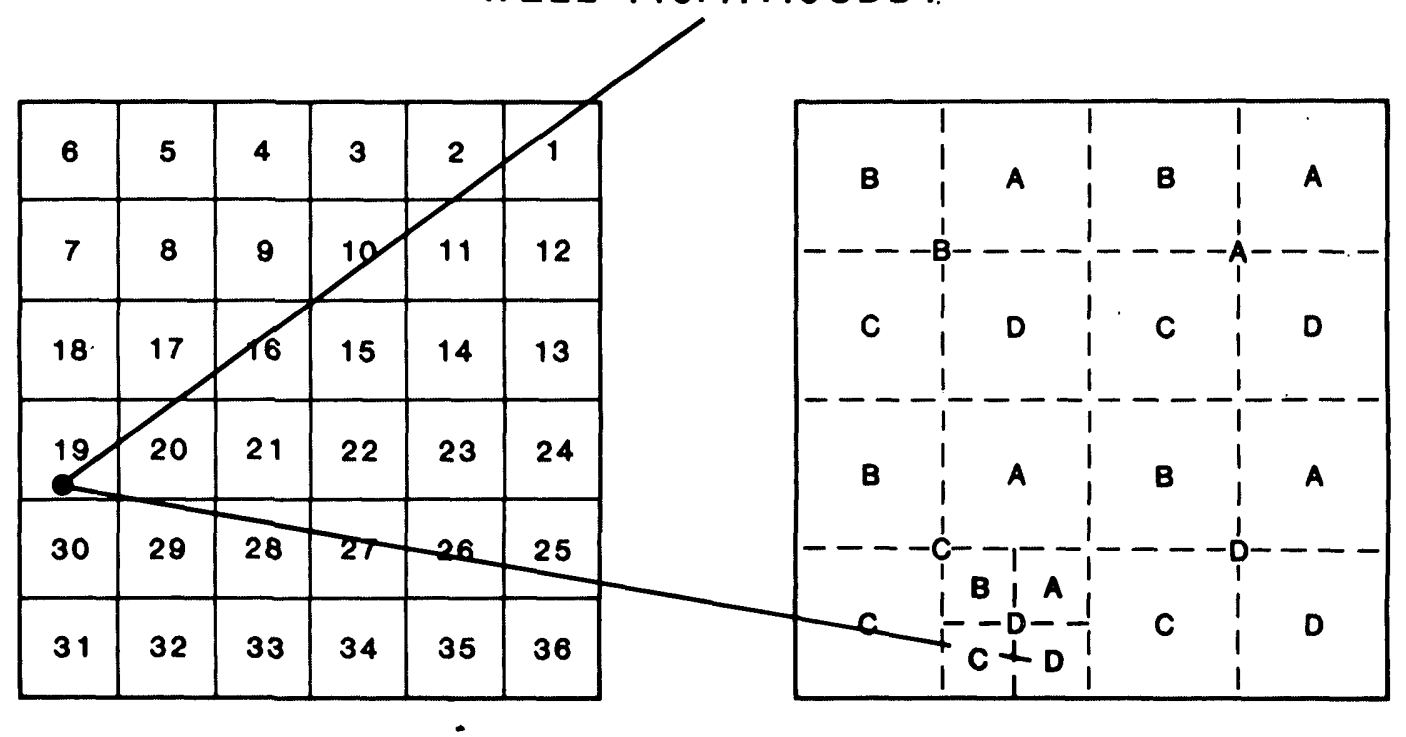

Figure 2.--Test-hole and well-numbering system 


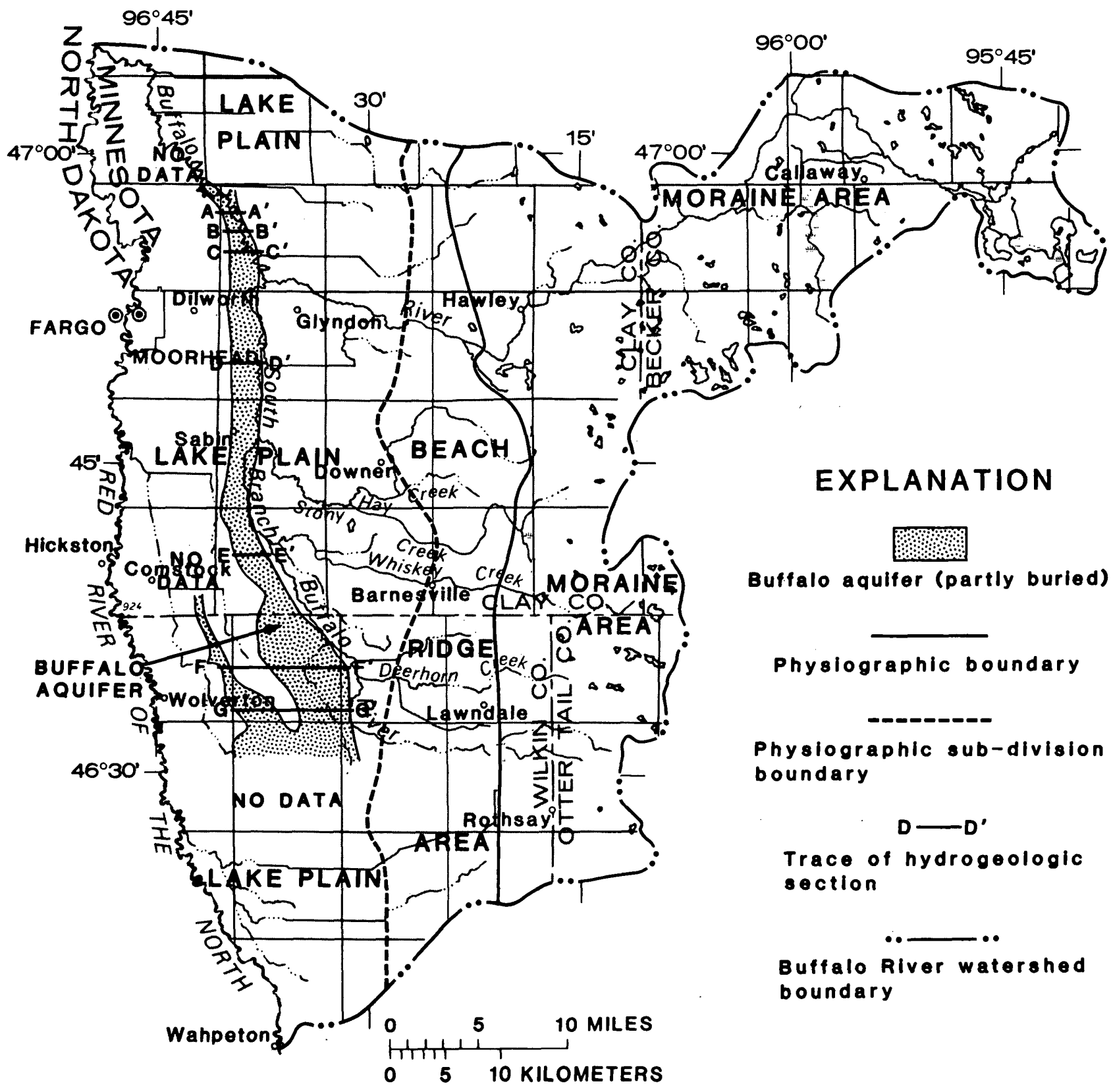

FIgure 3.--Physlographlc divislons of the Buffalo River watershed and trace of the hydrogeologlc sectlons of the Buffalo aqulfer 
The lake plain, formed by Glacial Lake Agassiz nearly 10,000 years ago, is an extensive flat area. It slopes only a few feet per mile to the west toward the Red River of the North, is poorly drained, and is subject to widespread flooding nearly every spring. Ditching on the lake plain has been extensive to remove storm runoff and to drain wetlands.

The lake plain is underlain predominately by clay, with local areas of silt and sand. The silt and sand was deposited near the shore, and the clay was deposited in the deeper part of the lake. The lake plain is bordered by sand and gravel beach ridges, which mark the former extent of various stages of the glacial lake.

The western part of the moraine area is gently rolling, but steep hills occur in the eastern part. The hillslopes are generally well drained, but numerous closed depressions contain marshes or lakes. The moraine is composed of till containing fine to medium gravel and scattered boulders. Soils developed on the till are sandy clay silt loams.

\section{Climate}

The climate is of the continental type, typical of temperate zones at latitude $47^{\circ}$ north. Normal monthly temperatures at Fargo, N. Dak., range from $5.9^{\circ} \mathrm{F}$ in January to $70.7^{\circ} \mathrm{F}$ in July, based on the period 1941-70. Normal annual temperature is $40.7^{\circ} \mathrm{F}$.

Normal annual total precipitation for the area underlain by the Buffalo aquifer is about 20 inches (Baker and Kuehnast, 1978, p. 12). Approximately two-thirds of the annual precipitation is rain during the growing season, May through September.

Records from the National Weather Service (NOAA, 1977; 1978; 1979) show that total annual precipitation at Fargo was 8.84 inches in 1976, 32.28 inches in 1977, and 17.44 inches in 1978. Cumulative departure of monthly total precipitation from the 1941-70 normal monthly precipitation is shown in figure 4 for Fargo and Wahpeton, N. Dak., for the 1977-78 water years.

\section{Hydrogeology}

Rocks underlying the Buffalo River area are of Precambrian, Cretaceous, and Quaternary age. Precambrian and Cretaceous rocks are covered by Quaternary drift deposits.

\section{Bedrock}

Basement rock consists of Precambrian igneous and metamorphic rocks (Sims, 1970). These hard, dense rocks have low porosity and hydraulic conductivity. Some water occurs in fractures in the rock and in weathered 


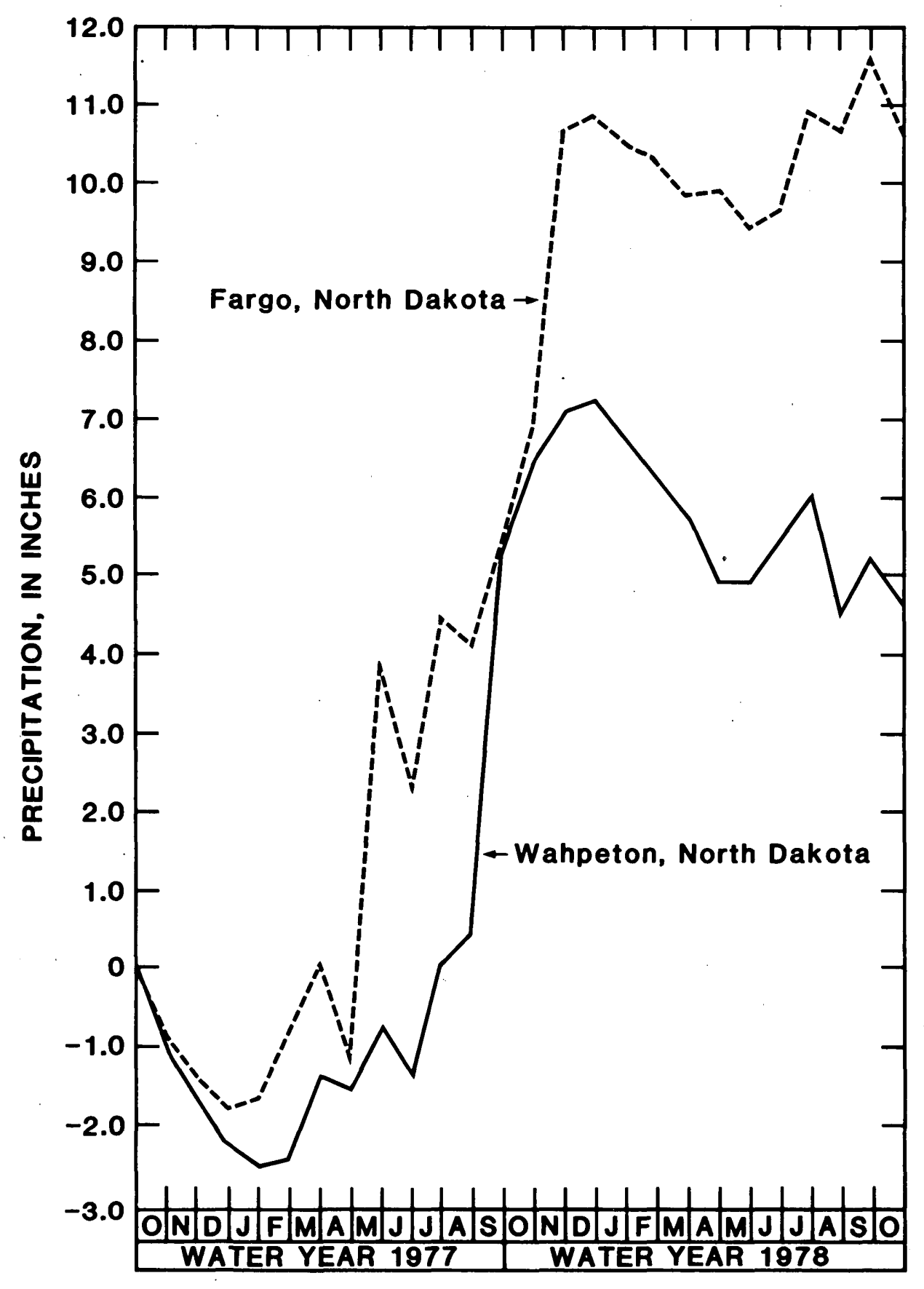

Flgure 4.--Cumulative departure of monthly total precipitation at Fargo and Wahpeton, North Dakota for the 1977-78 water years from the 1941-70 normal monthly preclpitatlon 
zones near the top, but expected well yields are less than $10 \mathrm{gal} / \mathrm{min}$. The top of the Precambrian rocks, delineated by extensive surface electricalresistivity surveys (Zohdy and Bisdorf, 1979) is shown in figure 5. This surface shows the lowest depth that high-yielding wells occur.

Cretaceous sedimentary rocks overlie the Precambrian basement rocks and underlie the drift. The rocks are generally soft varicolored shale, but locally contain some poorly consolidated or loosely cemented siltstone and sandstone. The Cretaceous rocks are discontinuous and thin in the northern part of the Buffalo aquifer area, but reach thicknesses of a few hundred feet in the southern part. The water-yielding potential of the Cretaceous rocks is low; however, some wells in the sandstone may yield as much as $50 \mathrm{gal} / \mathrm{min}$.

Drift

Drift overlies Cretaceous sedimentary or Precambrian crystalline bedrock over the entire study area. In the morainal area in the eastern part of the watershed, till extends from land surface to bedrock, but, in the lake plain in the western part of the area, till is covered by lake sediments or by beach ridge deposits.

\section{Buried aquifers}

In addition to the Buffalo aquifer, other aquifers occur at various depths within the drift. These buried aquifers are elongate, discontinuous lenses of sand and gravel deposited as outwash in glacial meltwater stream channels or as kames in ice-contact deposits.

Locating and delineating the buried aquifers is difficult because (1) they have no surface expression, (2) the available logs are from widely scattered test holes and wells, and (3) many of the test holes and wells do not penetrate the entire thickness of the glacial deposits.

One approach to delineating buried aquifers is to map the bottom elevation of wells (Rodis, 1961). Modifying this approach to use the top of the aquifer, four zones of buried aquifers have been mapped in the western part of the watershed and are shown in figure 6 . The deepest zone is closest to the Red River, and the zones ascend, with some overlapping, in a steplike manner from west to east. As more data become available, individual aquifers within the zones can be mapped in greater detail.

Some buried deposits are areally extensive but thin; others are thick but discontinuous and of small areal extent. Wells completed in these deposits may have initial yields of about $1,000 \mathrm{gal} / \mathrm{min}$, but these yields generally cannot be sustained for long periods. Yields sufficient for domestic and rural supplies are common from wells completed in the buried aquifers, and a few wells yield supplies adequate for irrigation and for some industrial uses. 
NORTHERN PORTION OF STUDY AREA

EXPLANATION R 40' 96'35'

EXPLANATION

T. $140 \mathrm{~N}$

LINE OF EQUAL DEPTH TO PRECAMBRIAN BEDROCK--Dashed where approximately located. Interval 100 and 200 feet. Datum is land surface

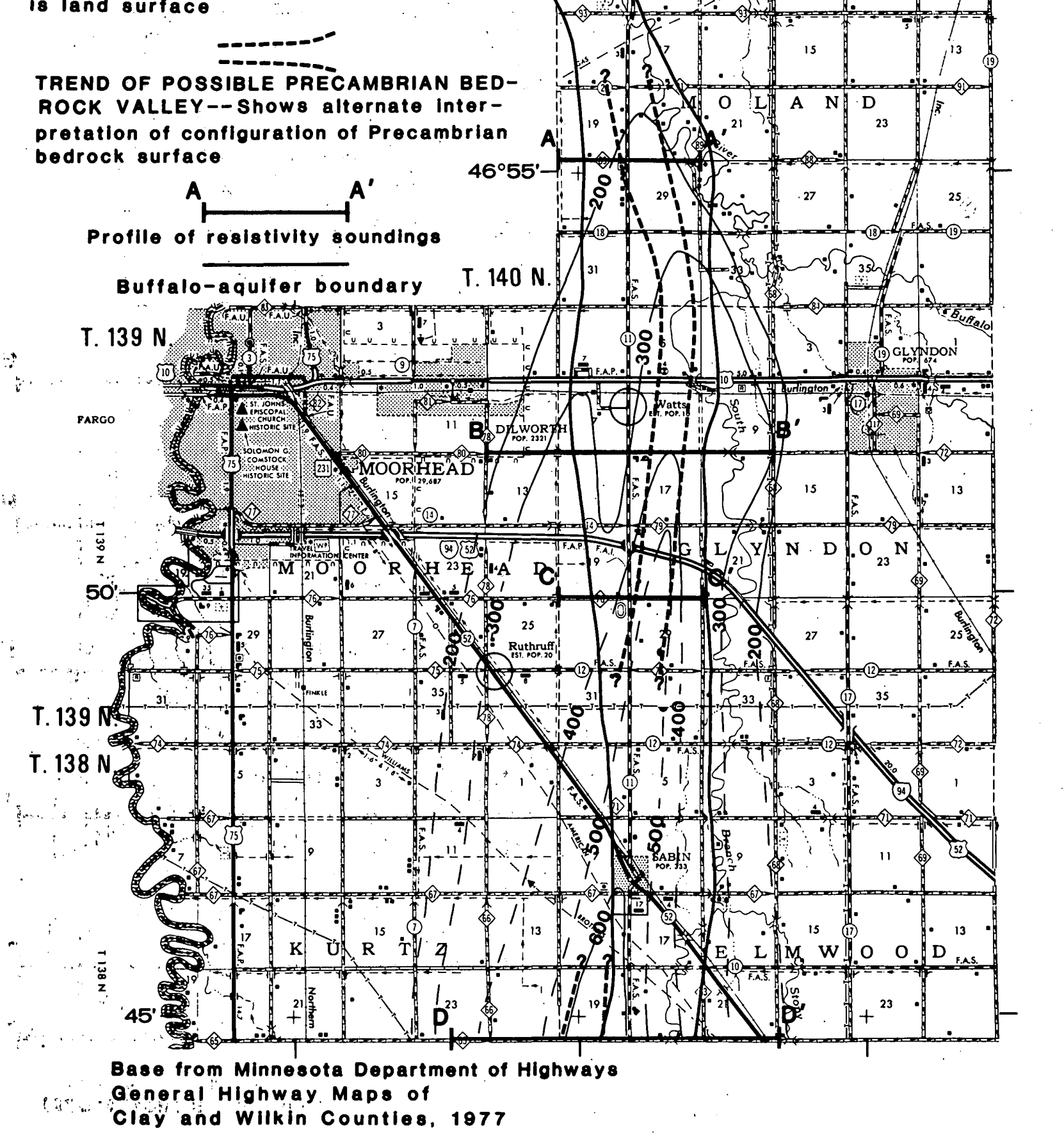

Flgure 5.--Possible depth to Precambrlan 


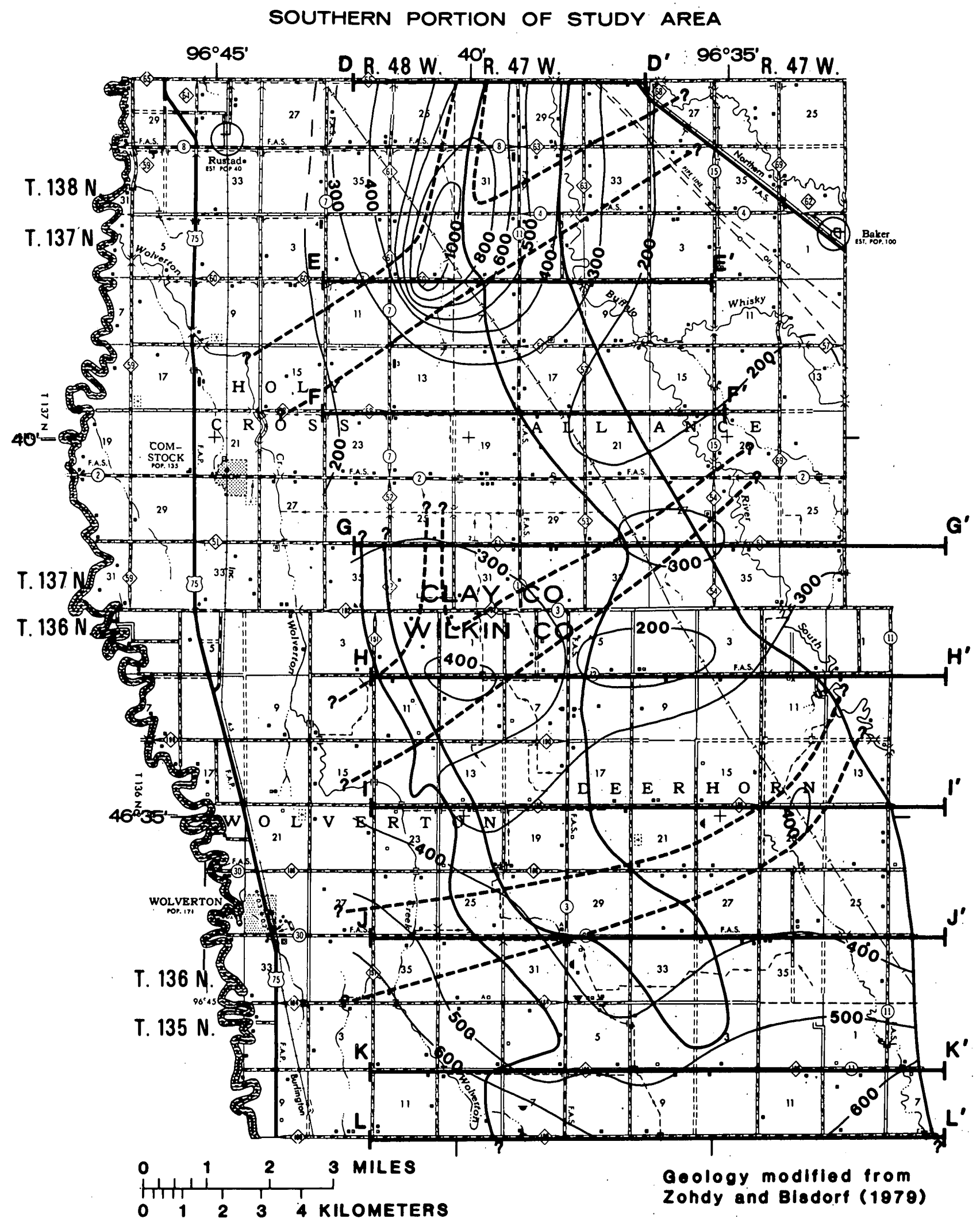

bedrock besed on surface reslstivity data 


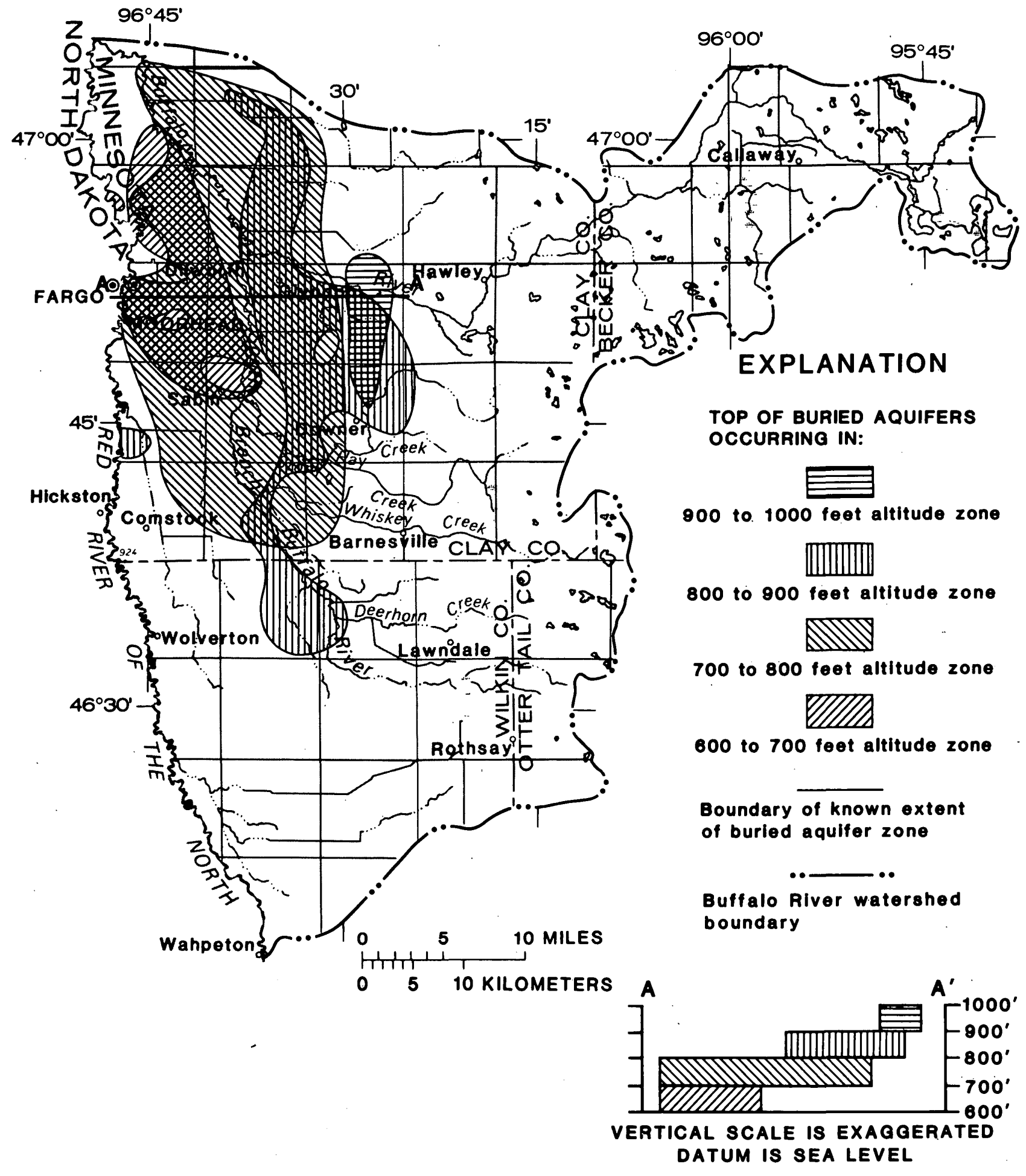

Flgure 6.--Known extent of burled aquifer zones In western part of Buffalo RIver watershed 
Head data are inadequate to map potentiometric surfaces in the buried aquifers. However, water levels measured in a few wells indicate that, in general, water percolates into the till in the higher morainal area and moves laterally westward toward the Red River of the North. Before and during early settlement of the Red River valley, there were numerous springs and flowing wells on the lake plain. As drainage ditches were dug and pumping from wells increased, water levels dropped, so that flowing wells at present (1979) can be obtained only in a small area.

The quality of water from wells completed in buried aquifers is poor. The water is of the magnesium sulfate, sodium bicarbonate, or sodium chloride types. Water type and concentration of predominate ions varies with depth and distance from the Red River of the North. Aquifers that are deepest and closest to the river generally contain water of the poorest quality. Pumping from shallower buried aquifers may change head differences and induce upward movement of water containing higher concentrations of sodium, sulfate, and chloride.

\section{BUFFALO AQUIFER EVALUATION}

$$
\text { origin }
$$

Winter (1967) attributed the origin of the sand and gravel that form the Buffalo aquifer to deposition by streams flowing from the glacial ice lobe into a proglacial lake. When the relatively narrow ice lobe, which lay along the axis of the Red River, was reduced by melting, a proglacial lake extended up the lowland along its sides. Meltwater streams deposited coarser sediments adjacent to the ice front and carried the finer material farther eastward into the lake basin. As the ice front retreated to the west, lake sediments accumulated west of the sand deposit.

An alternate interpretation by Winter (1967) is that the sediment in streams flowing from the ice was deposited in large ice cracks. Upon melting of the ice surrounding the cracks, the sand became interfingered with or graded into the lake sediments being deposited on both sides of it in the proglacial lake. With either interpretation, the sand and gravel body was deposited at an early stage of Glacial Lake Agassiz, as indicated by the fact that the sand lies directly on till with no intervening layer of lake sediments. Lake sediments accumulated on both sides of the sand and at a later stage covered the sand deposit.

Another interpretation was offered by Guyton and Associates (1957). They considered the aquifer to be an ice-contact deposit, probably a deltakame. They depicted a south-flowing torrential stream running from an ice mass into ponded water, forming a delta. The great length of the deposit resulted from the slow northward waning of the leading edge of the glacier. As a result of being deposited in ponded water, the coarse sand and gravel, which is in contact with the till below, was surrounded by fine sand and then by increasing proportions of silt and clay. 
NORTHERN PORTION OF STUDY AREA

EXPLANATION

R. $48 . W$. 4Q. 47 W. $96^{\circ} 35^{\circ}$

T. $140 \mathrm{~N}$

STRUCTURE CONTOUR--ShOW

altitude of top of Buffalo aquifer.

Contour interval 20,40 , and 60

foet. Datum is soa level

Buffalo-aquifer boundary
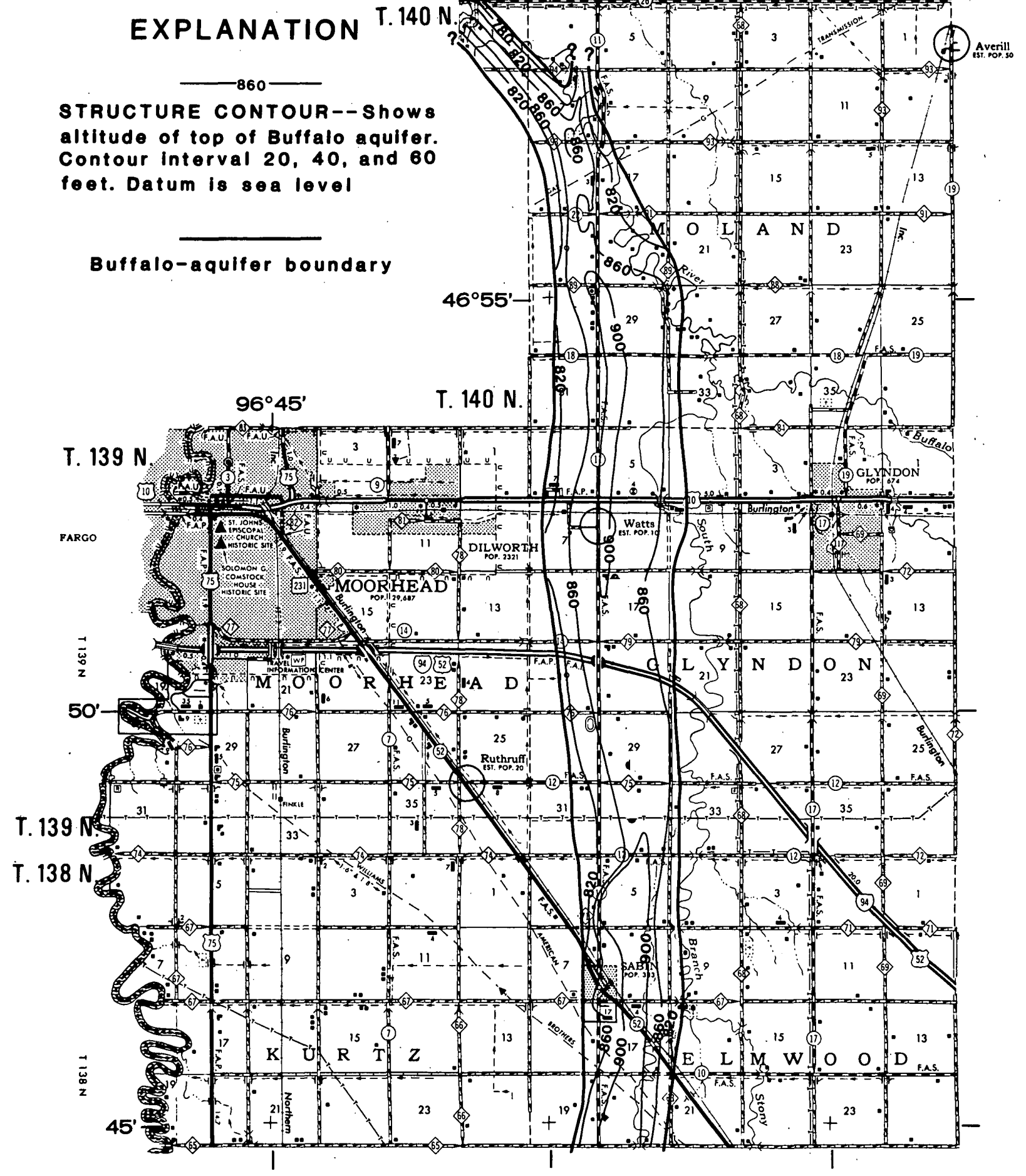

Flgure 7.-.Conflguration of the 


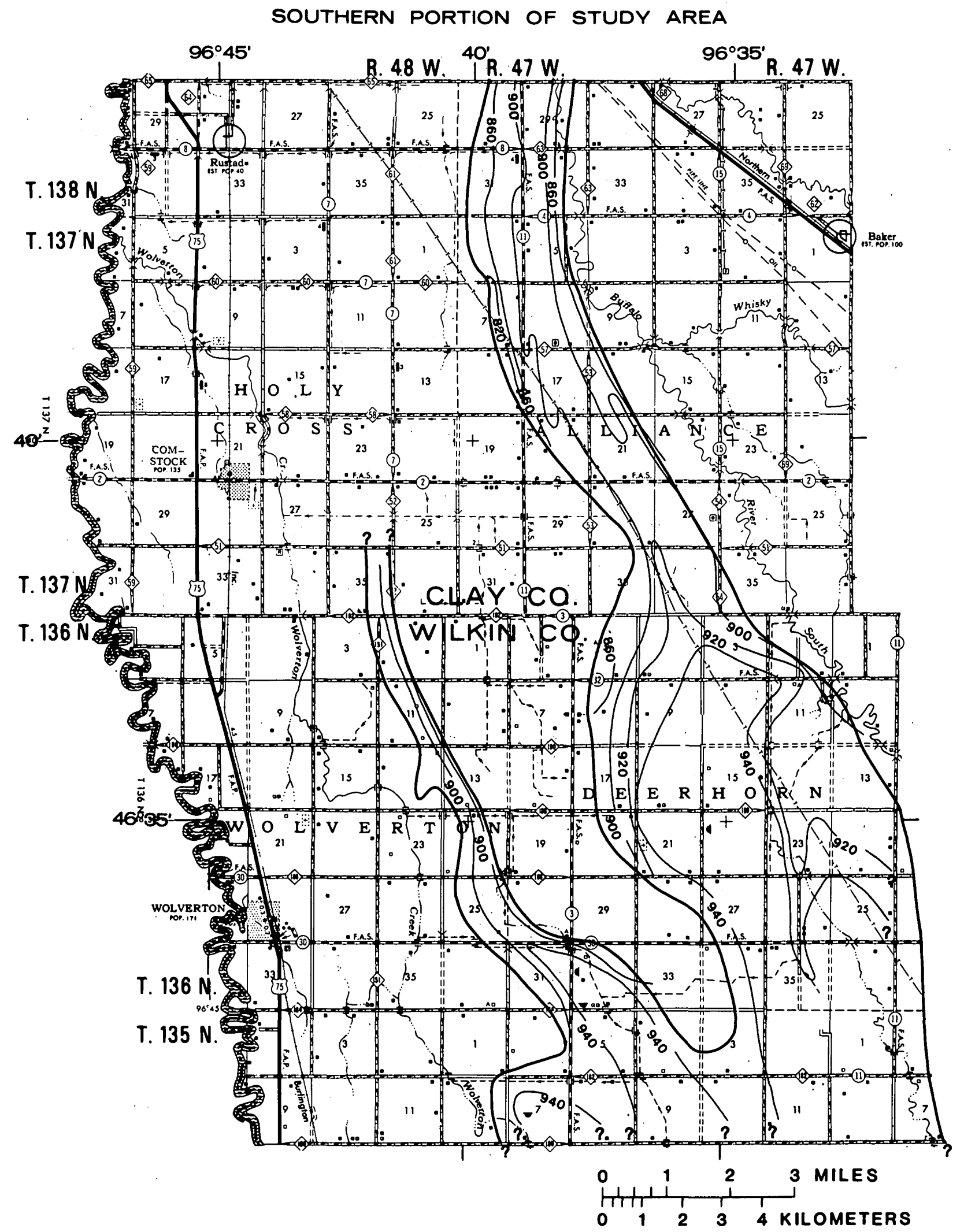

top of the Buffalo aquifer 
NORTHERN PORTION OF STUDY AREA

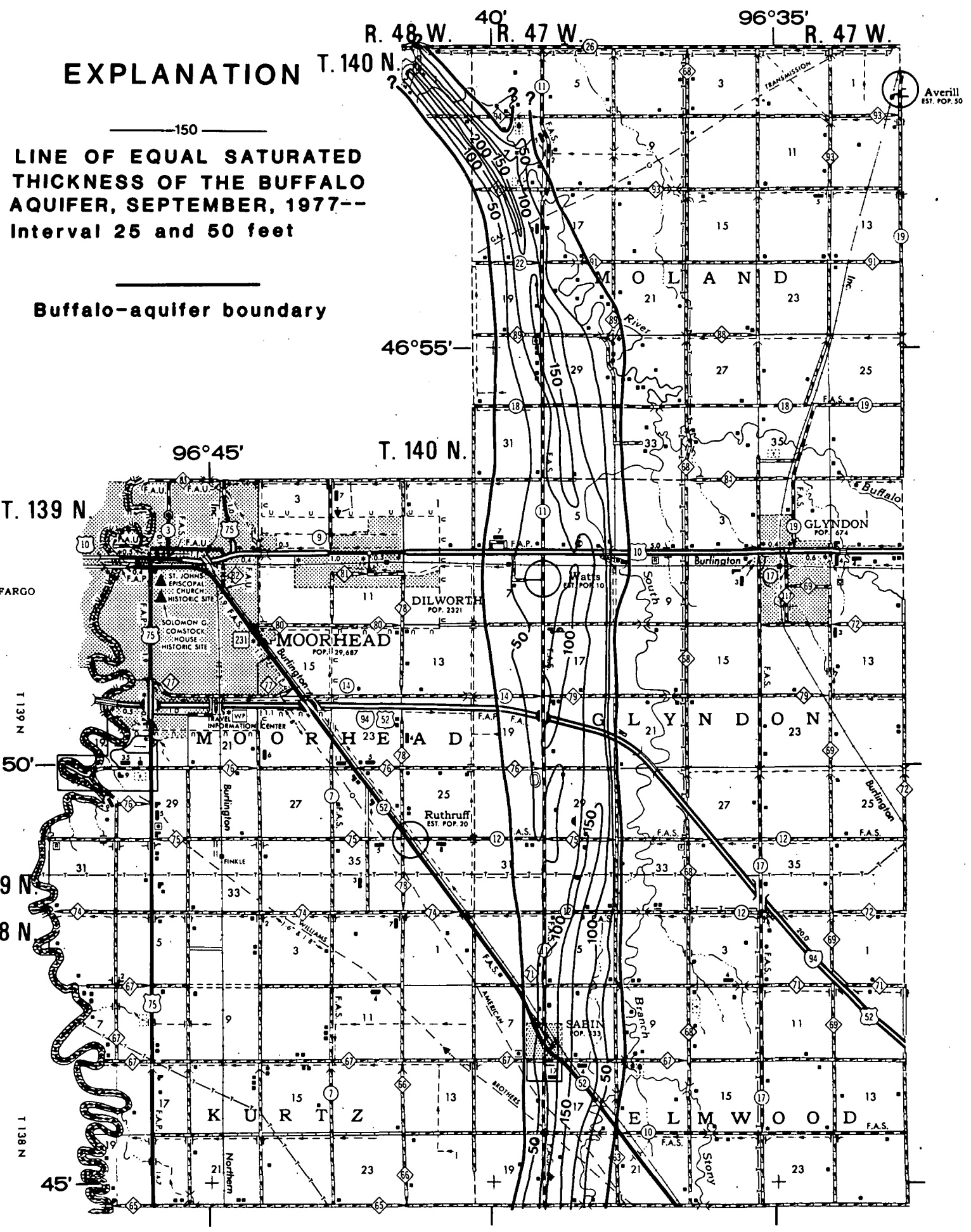

FIgure 8.--Saturated thlckness 
SOUTHERN PORTION OF STUDY AREA

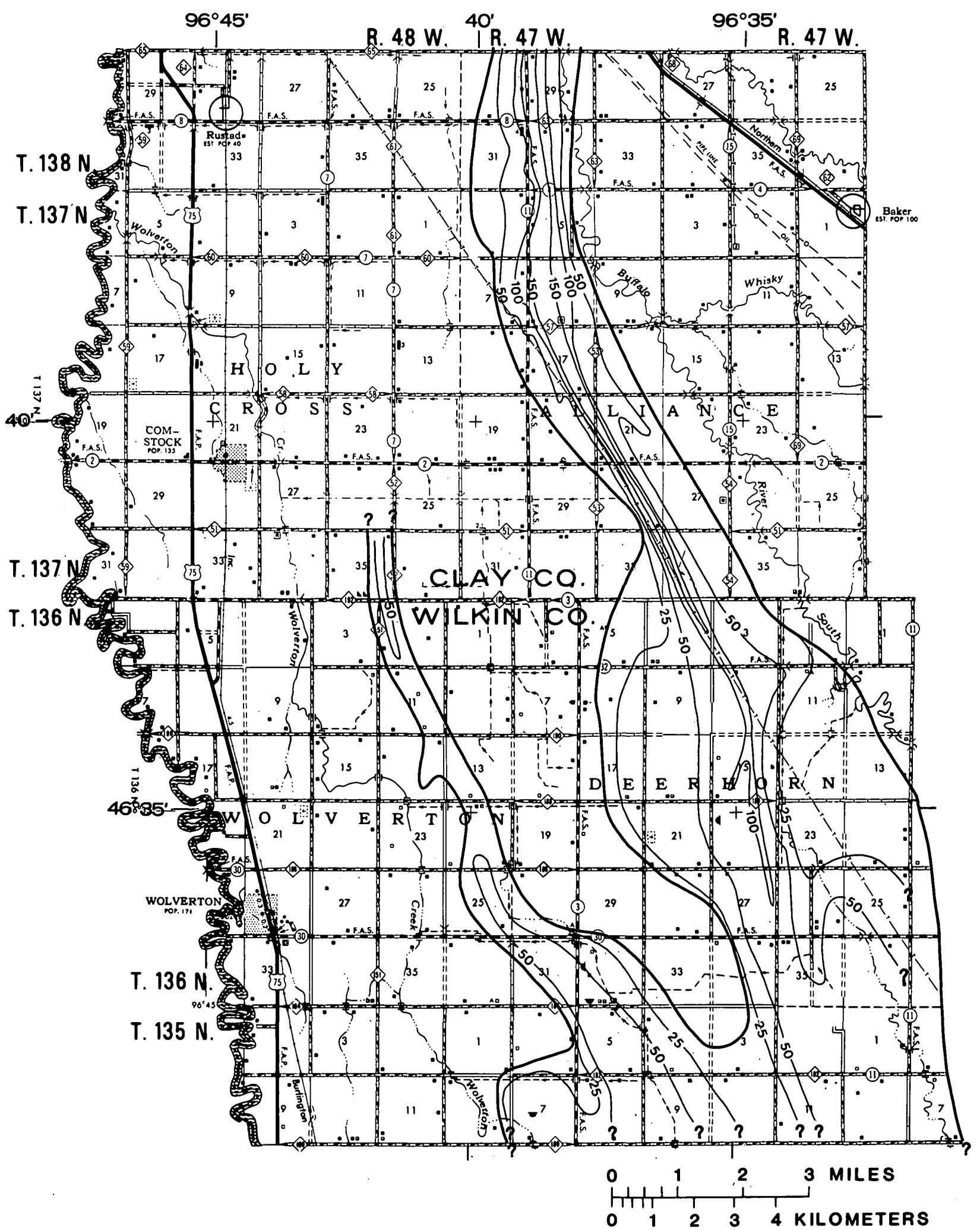

of the Buffalo aquifor 
NORTHERN PORTION OF STUDY AREA

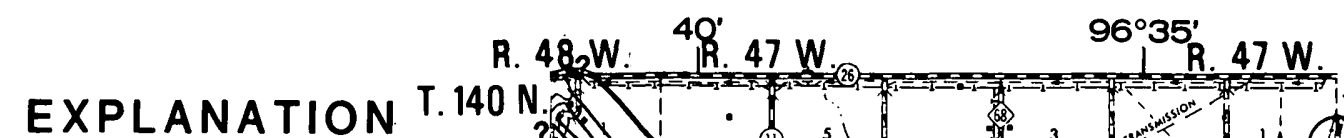

STRUCTURE CONTOUR--ShOWB

altitude of top of till surface underlying the Buffalo aquifer. Contour Interval 20 and 40 feet. Datum is sea level

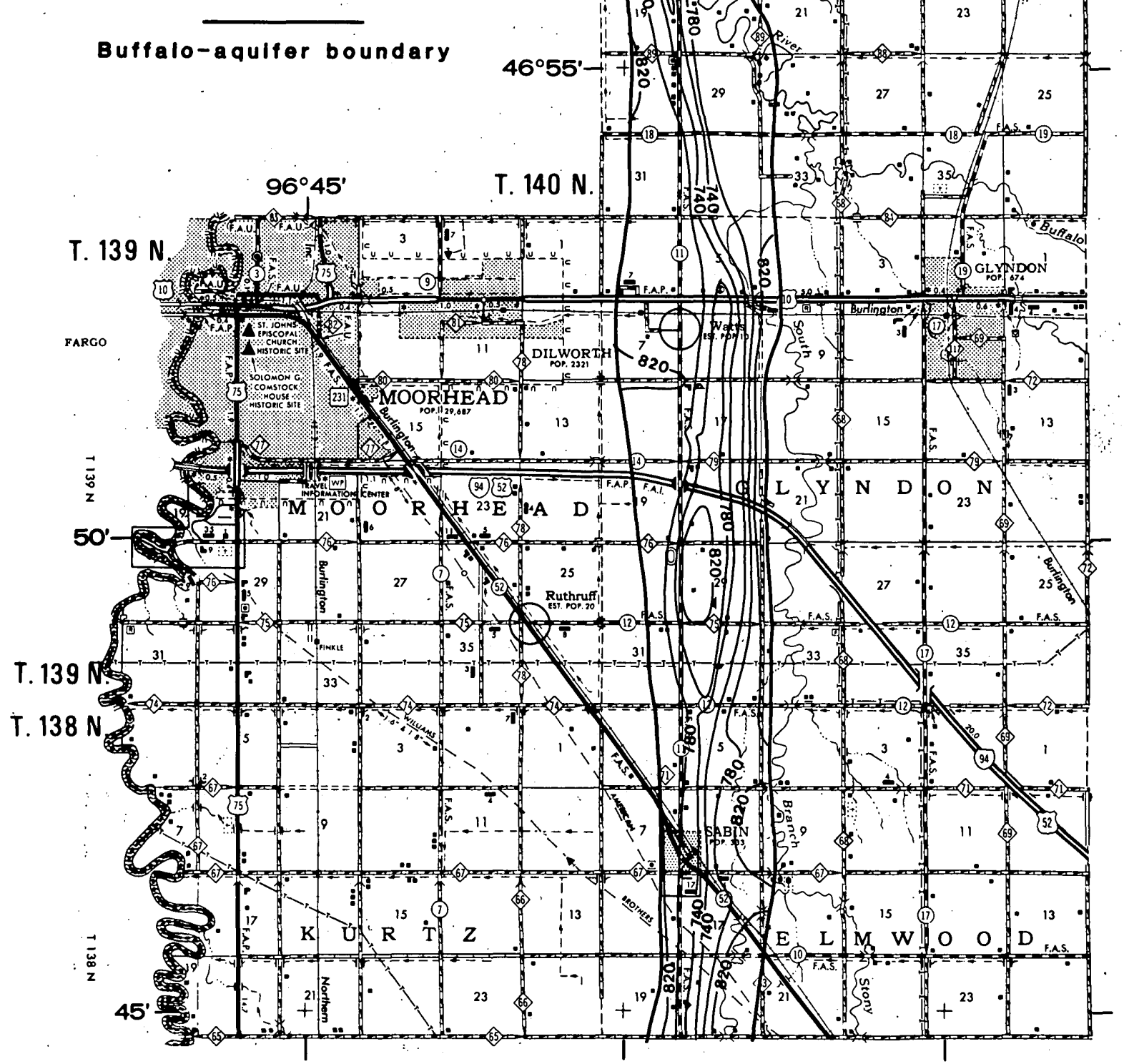

Flgure 9.--Conflguration of the tIII 


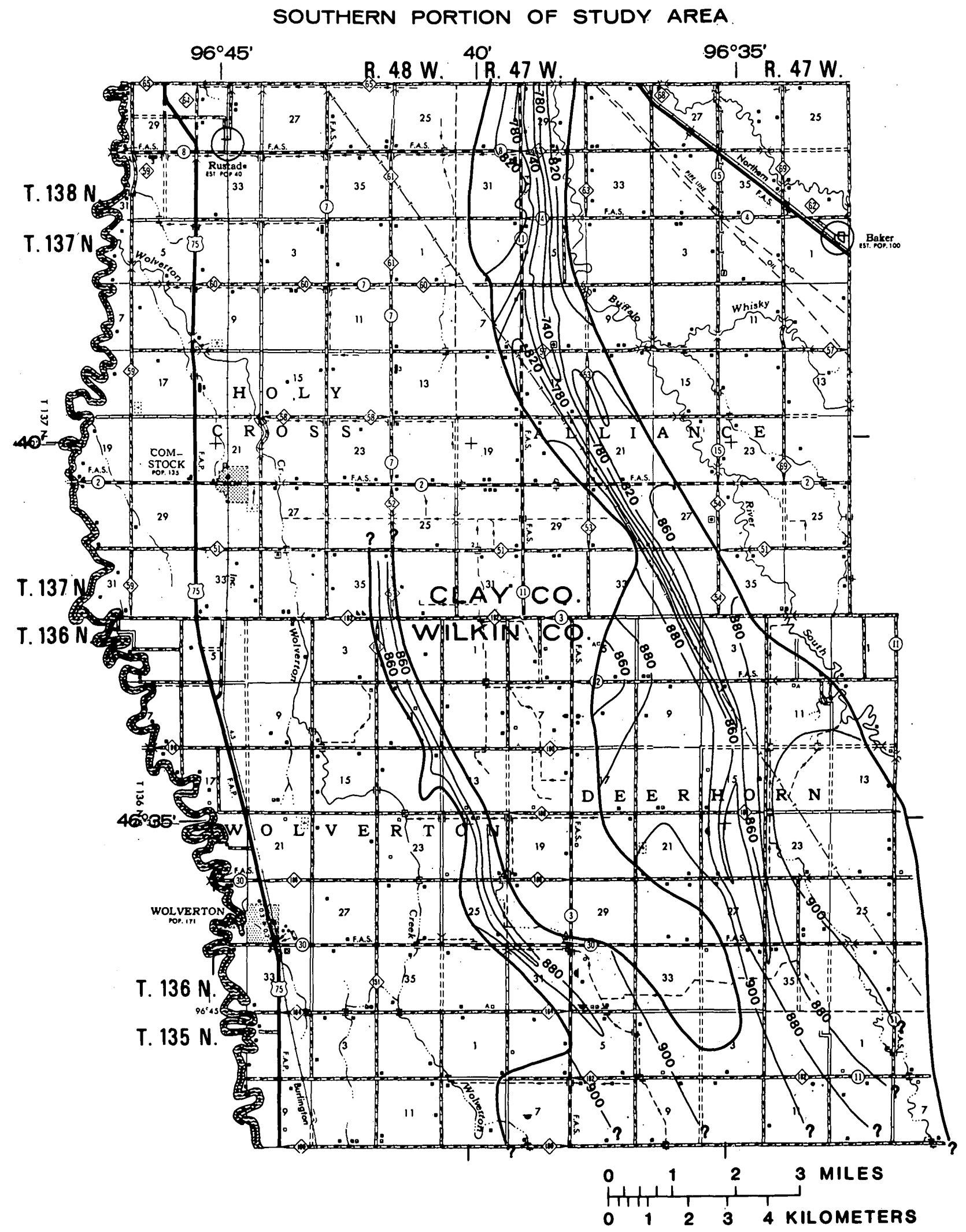

surface underlying the Buffalo aqulfer 


\section{Physical Characteristics}

The Buffalo aquifer is an elongate sand and gravel body from 1 to 8 miles wide and about 32 miles long. It is roughly diamond shaped in section. It ranges in thickness from only a few feet at the outer edges to about 200 feet locally along the axis. The configuration of its top is shown in figure 7. Its areal extent and saturated thickness is shown in figure 8. The aquifer is 10 to 15 feet thicker than the saturated thickness shown in the southern part of the area. Deep drilling during this study has revealed a previously unknown deep, narrow trough along the axis of the aquifer. Configuration of the bottom of the aquifer is shown in figure 9 and indicates the approximate location of the deep trough. The trough is also shown on some of the hydrogeologic sections (figs. 10,11,12,13,14, and 15). The sections indicate the relation of streams to the aquifer. Although the river may lie above the east edge of the aquifer, there is generally little hydraulic connection between them because the edge of the aquifer mostly lies deeply buried under lake sediments. Most leakage between aquifer and river must pass through these thick, slightly permeable lake sediments. The potentiometric surface in September 1977 is also shown on the sections.

The aquifer material ranges in size from fine sand to gravel. The coarser material, mostly medium to coarse $s$ and with gravel and some cobbles, is in the lower part of the narrow trough. The sand grades laterally, both eastward and westward, into very fine sand, silt, and clay. With data from only a few widely scattered test holes near the edges, it is difficult to determine if the sand grades into or is interfingered with the fine-grained lake sediments.

\section{Thickness of Overlying Confining Bed}

The lake clay and silt beds overlying the Buffalo aquifer vary in thickness areally, as shown in figure 16. The map shows that the lake sediments are 80-120 feet thick near the outer edges and 20 feet thick or less in the middle of the aquifer. Lake sediments are absent and $s$ and is exposed at land surface over a large area in Wilkin County. The lake sediments are very thin in a few locations beneath the Buffalo River and South Branch Buffalo River where the stream meanders over the top of the aquifer. Some of these locations, as shown in figure 16, are along the rjver in $W / 2$ $\mathrm{NE}^{1} / 4$ and $\mathrm{NW} / 4 \mathrm{SE}^{1} / 4$, sec. $5, \mathrm{~T}$. $139 \mathrm{~N}$., R. $47 \mathrm{~W}$., $\mathrm{NE} / 4 \mathrm{SW}^{1} / 4 \mathrm{SE}^{1} / 4 \mathrm{sec} .7$ and parts of $\mathrm{NW}^{1} / 4$ and $\mathrm{E} / 2 \mathrm{SW}^{1} / 4$, sec. $20, \mathrm{~T} .140 \mathrm{~N} ., \mathrm{R} .47 \mathrm{~W}$.

\section{Hydraulic Characteristics}

Important hydraulic characteristics of an aquifer are hydraulic conductivity, saturated thickness, and storage coefficient. These characteristics can be used to determine rates and magnitudes of water-level changes resulting from withdrawal or injection of water from or into an aquifer. 


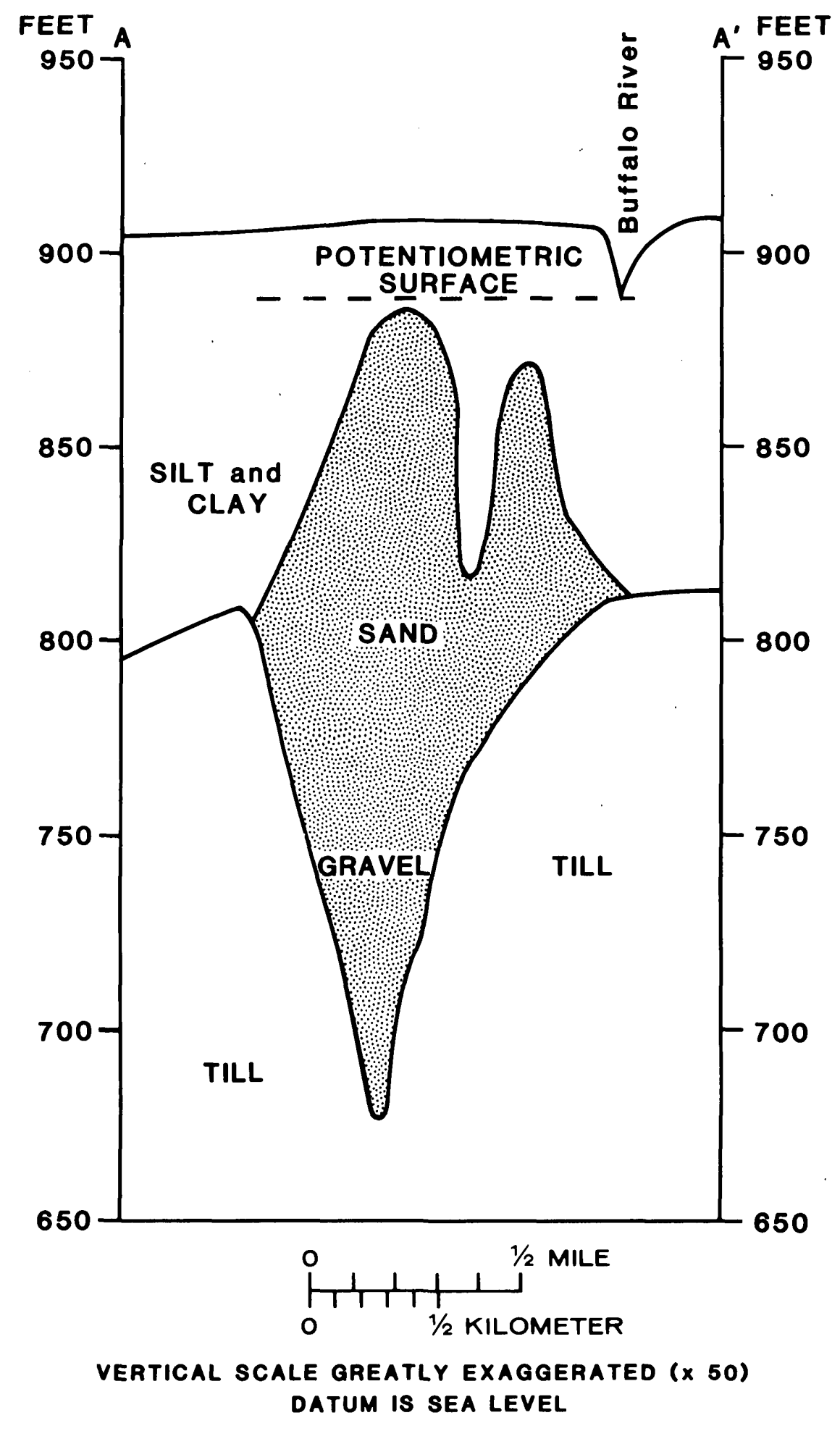

Figure 10.--Hydrogeologic sectlon A-A' northeast of Moorhead 


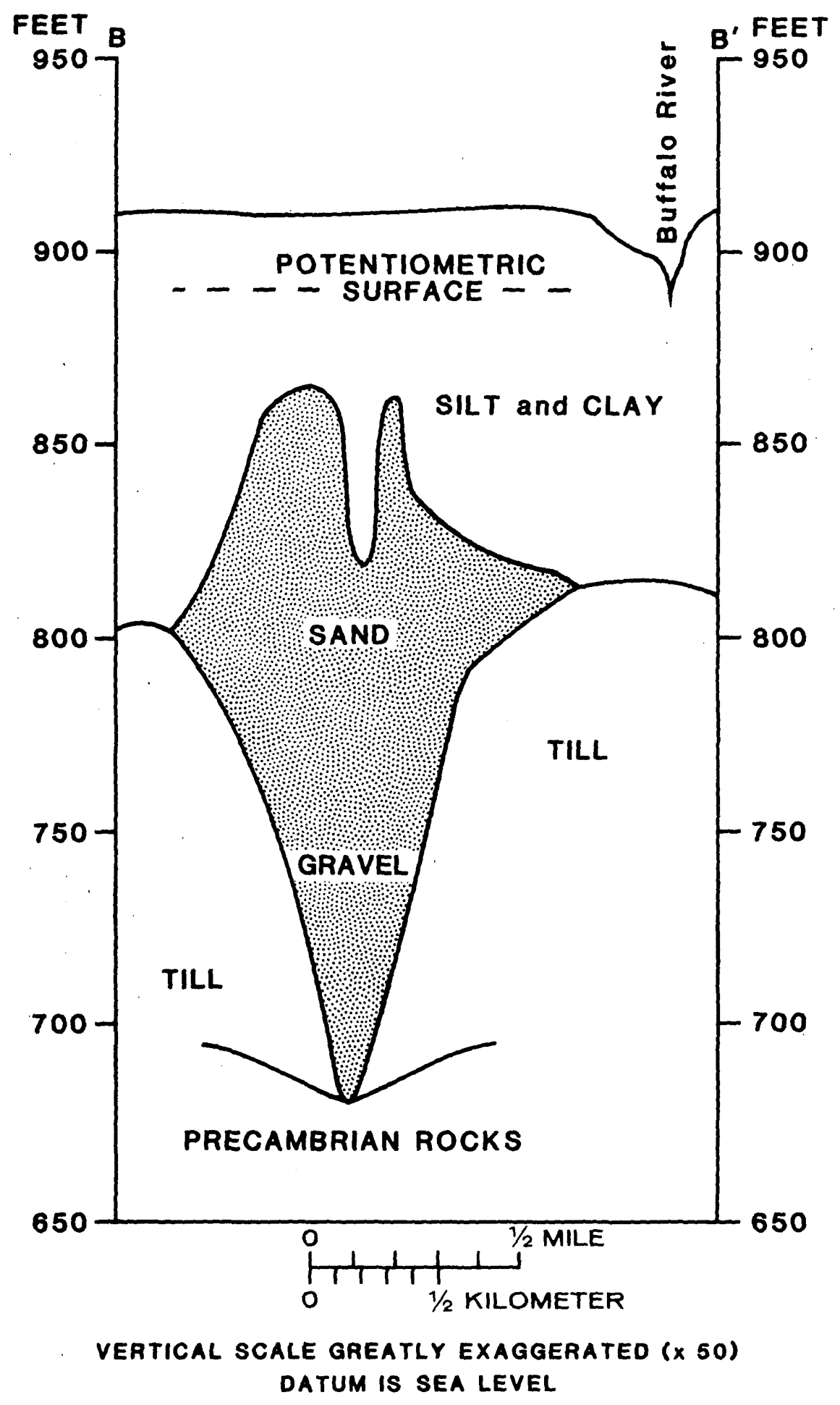

Flgure 11.--Hydrogeologic section B-B' northeast of Moorhead 


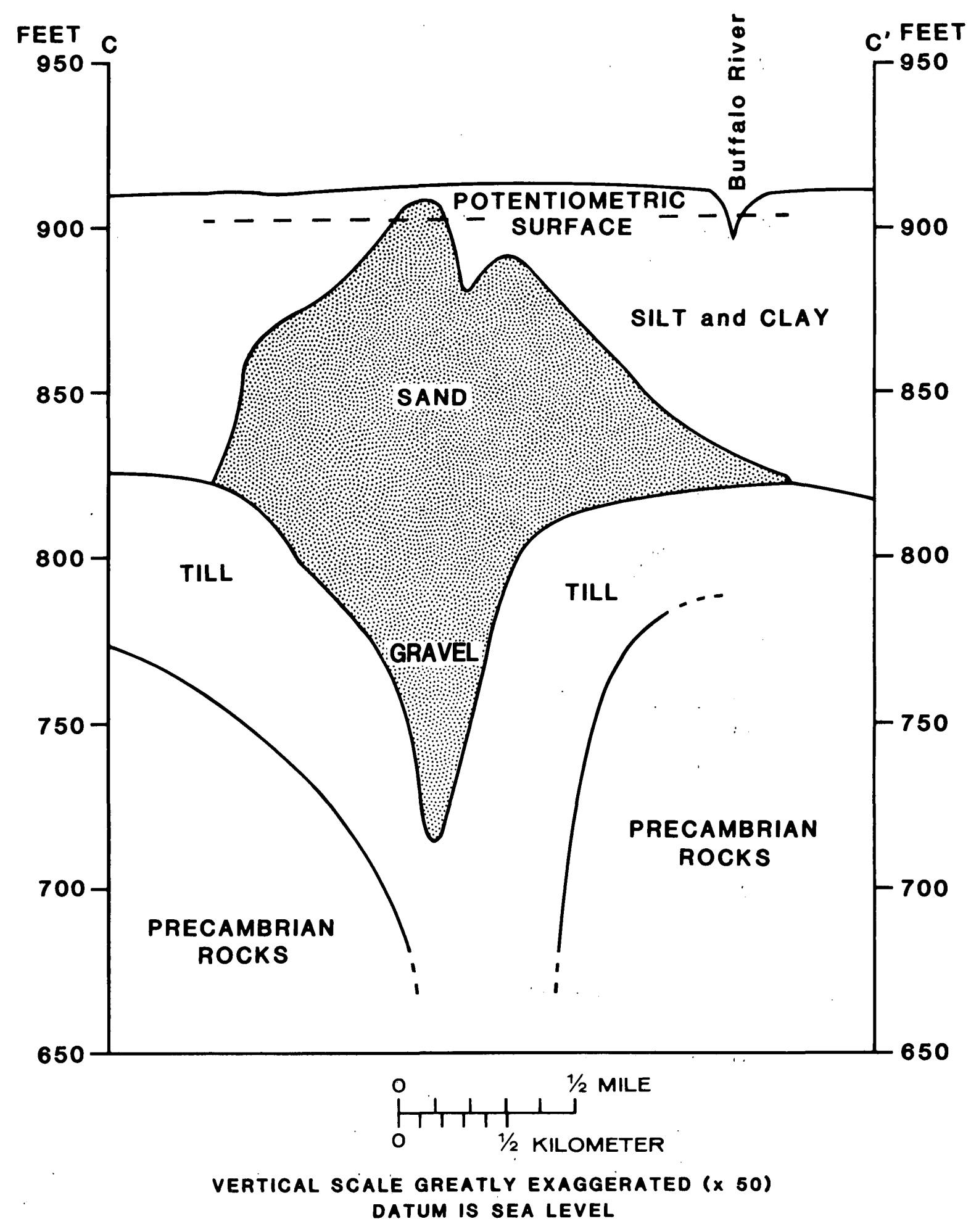

Figure 12.--Hydrogeologic section C-C' northeast of Moorhead 


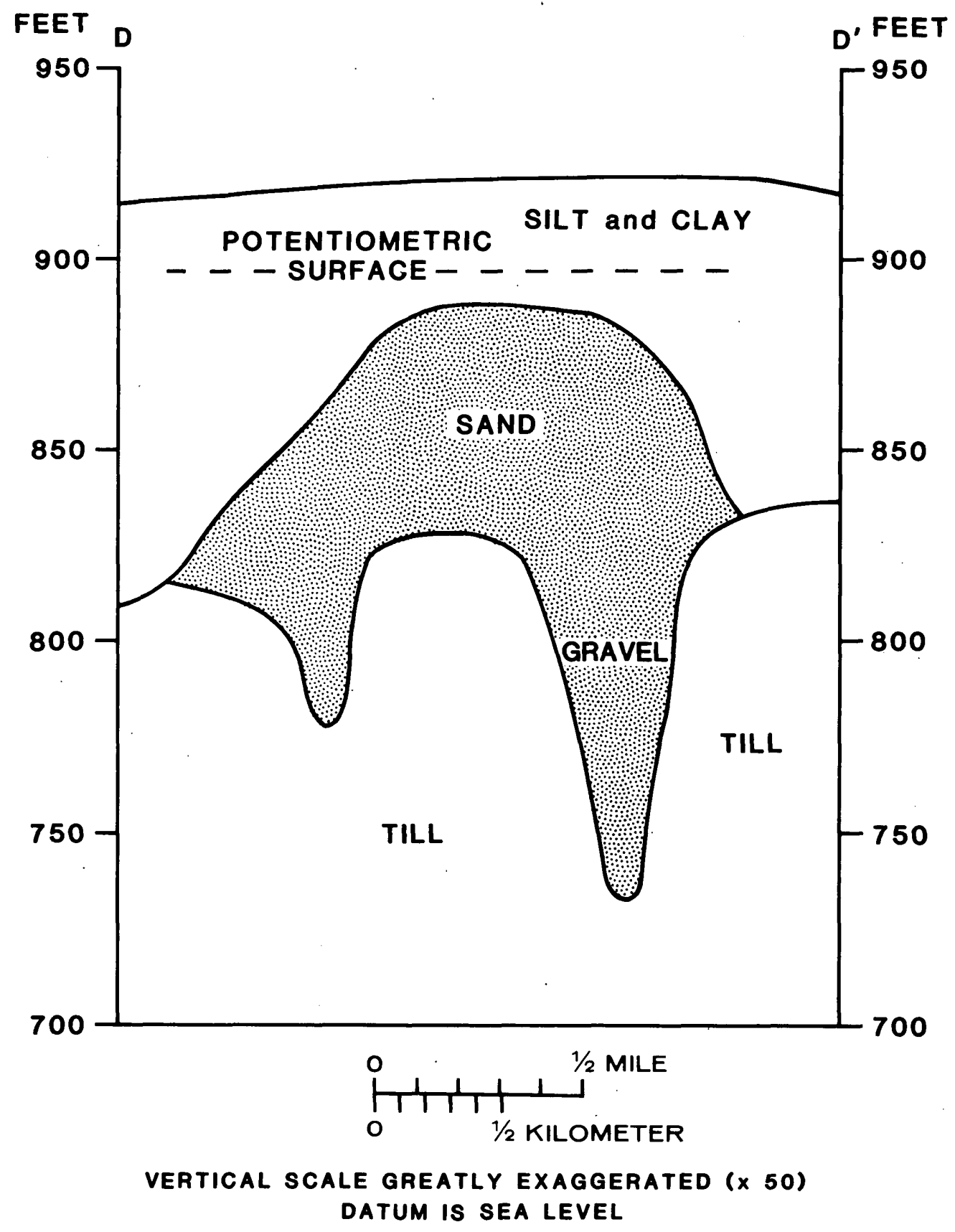

Figure 13.--Hydrogeologic section D-D' southeast of Moorhead and north of Sabin 


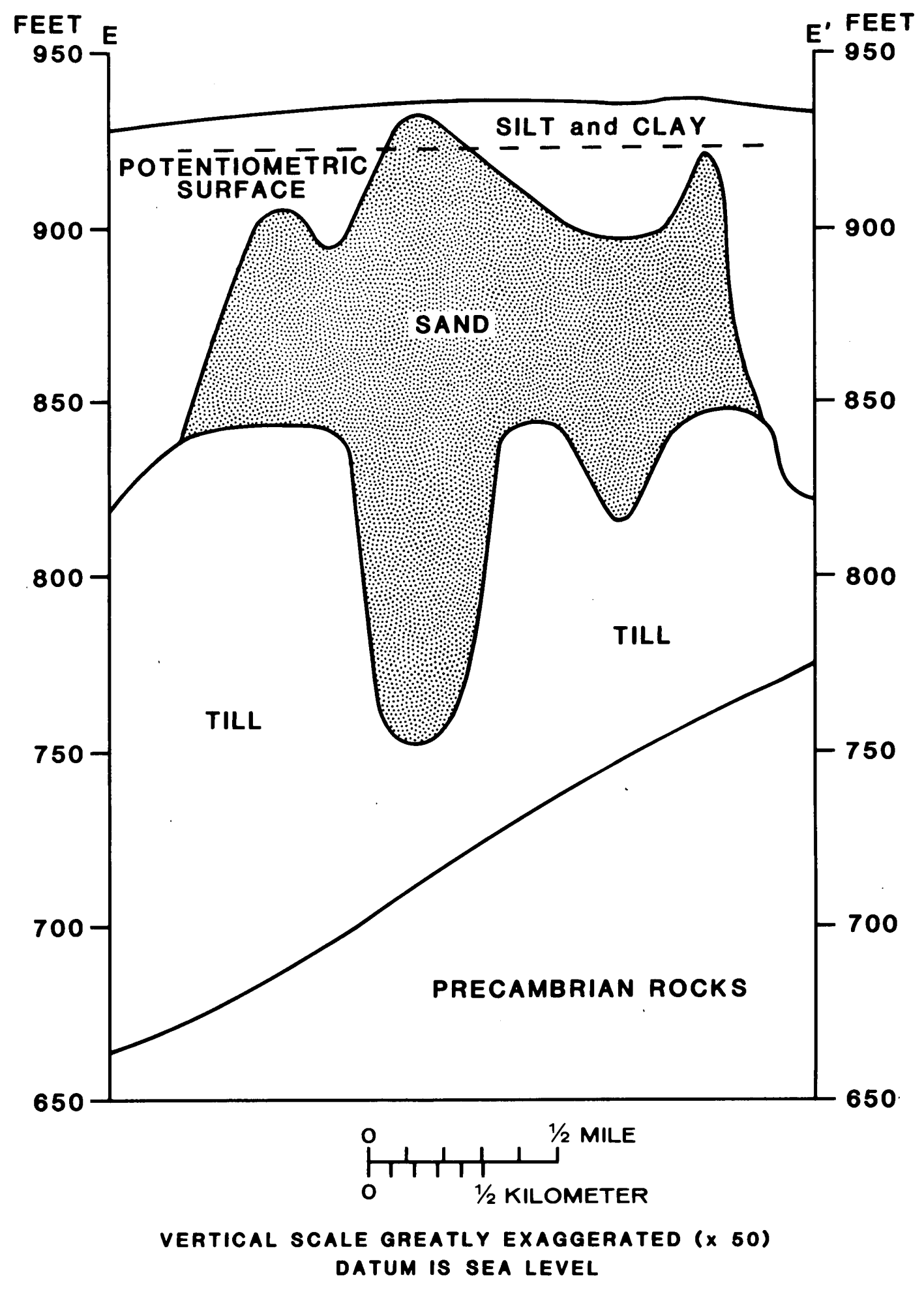

FIgure 14.--Hydrogeologic section E-E' south of Sabin and west of Barnesville 


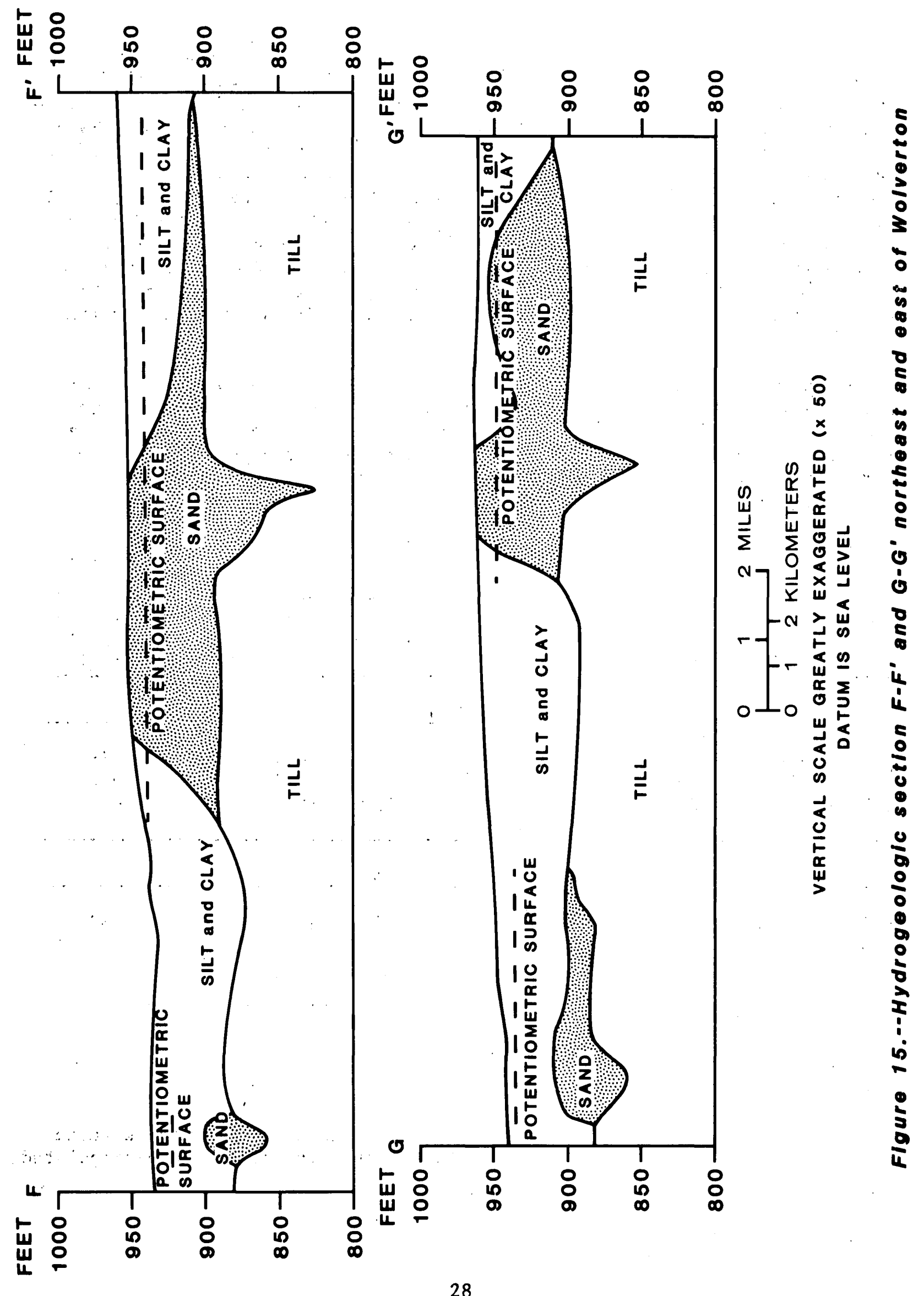


The hydraulic characteristics of the Buffalo aquifer were determined from aquifer tests and test-hole logs. Aquifer tests at three irrigationwell sites were analyzed by methods outlined in Lohman (1972). The average transmissivity of the aquifer at irrigation wel1 136.47.27DCB (Duane Swenson) was $19,500 \mathrm{ft}^{2} / \mathrm{d}$. Storage coefficient ranged from 0.082 to 0.106 , horizontal hydraulic conductivity ranged from 384 to $400 \mathrm{ft} / \mathrm{d}$, and vertical hydraulic conductivity ranged from 19 to $32 \mathrm{ft} / \mathrm{d}$. The ratio of horizontal to vertical hydraulic conductivity (ranging from 12:1 to 21:1) indicates that the aquifer is anisotropic and that water will move much more slowly in the vertical direction than in the horizontal. By the method described by Prickett (1965), the calculated time when gravity drainage ceased to influence drawdown at the five observation wells used in the test ranged from 508 to 1,606 minutes.

Similar analyses of data from aquifer tests at the sites of two other irrigation wells in the Buffalo aquifer are not possible because of the short duration of the tests. However, considerable data were accumulated that provide a basis for estimating the response of the aquifer to prolonged pumping. The following tabulation lists total drawdowns and specific capacities at the two sites.

\begin{tabular}{|c|c|c|c|c|c|c|c|}
\hline $\begin{array}{l}\text { USGS we11 } \\
\text { location } \\
\text { number }\end{array}$ & $\begin{array}{c}\text { Distance, } \\
r \\
(\mathrm{ft}) \\
\end{array}$ & $\begin{array}{r}\text { Well } \\
\text { depth } \\
(\mathrm{ft}) \\
\end{array}$ & $\begin{array}{c}\text { Pumping } \\
\text { rate } \\
\text { (gal/ } \\
\text { min) } \\
\end{array}$ & $\begin{array}{c}\text { Period } \\
\text { of } \\
\text { pumping } \\
(\mathrm{h})\end{array}$ & $\begin{array}{c}\text { Static } \\
\text { water- } \\
\text { level } \\
\text { depth } \\
(\mathrm{ft}) \\
\end{array}$ & $\begin{array}{l}\text { Total } \\
\text { draw- } \\
\text { down } \\
(\mathrm{ft}) \\
\end{array}$ & $\begin{array}{c}\text { Specific } \\
\text { capacity } \\
{[(\mathrm{gal} / \mathrm{min})} \\
/ \mathrm{ft}]\end{array}$ \\
\hline \multicolumn{8}{|c|}{ Paul Horn irrigation } \\
\hline $\begin{array}{l}139.47 .8 \mathrm{CAC} 2 \ldots \\
139.47 .8 \mathrm{CAC} 1 \ldots \\
139.47 .17 \mathrm{BAA} 1 .\end{array}$ & $2000^{---}$ & $\begin{array}{r}128 \\
130 \\
68\end{array}$ & $\begin{array}{l}2000 \\
--- \\
---\end{array}$ & $\begin{array}{l}24 \\
24 \\
24\end{array}$ & $\begin{array}{l}30.2 \\
32.2 \\
32.3\end{array}$ & $\begin{array}{r}15.48 \\
7.89 \\
0.35\end{array}$ & 129 \\
\hline
\end{tabular}

Max Goldberg irrigation well

\begin{tabular}{rrrrrrrr}
\hline 140.47 .32 CBA1 .. & --- & 101 & 900 & 8 & 24.5 & 5.9 & 169 \\
140.47 .32 CBA6.. & 15.0 & 87 & -- & 52 & 27.9 & 2.22 & -- \\
140.47 .32 CBA4.. & 44.5 & 90 & --- & 52 & 28.5 & 1.61 & -- \\
\hline
\end{tabular}

This table shows that wells pumped 1 to 2 days will produce. large yields with small drawdowns. Longer tests, however, are needed to predict the response of the aquifer to longer periods of pumping.

Hydraulic characteristics determined. from aquifer tests may be valid only in the immediate vicinity of the test site. Values may be extrapolated, 


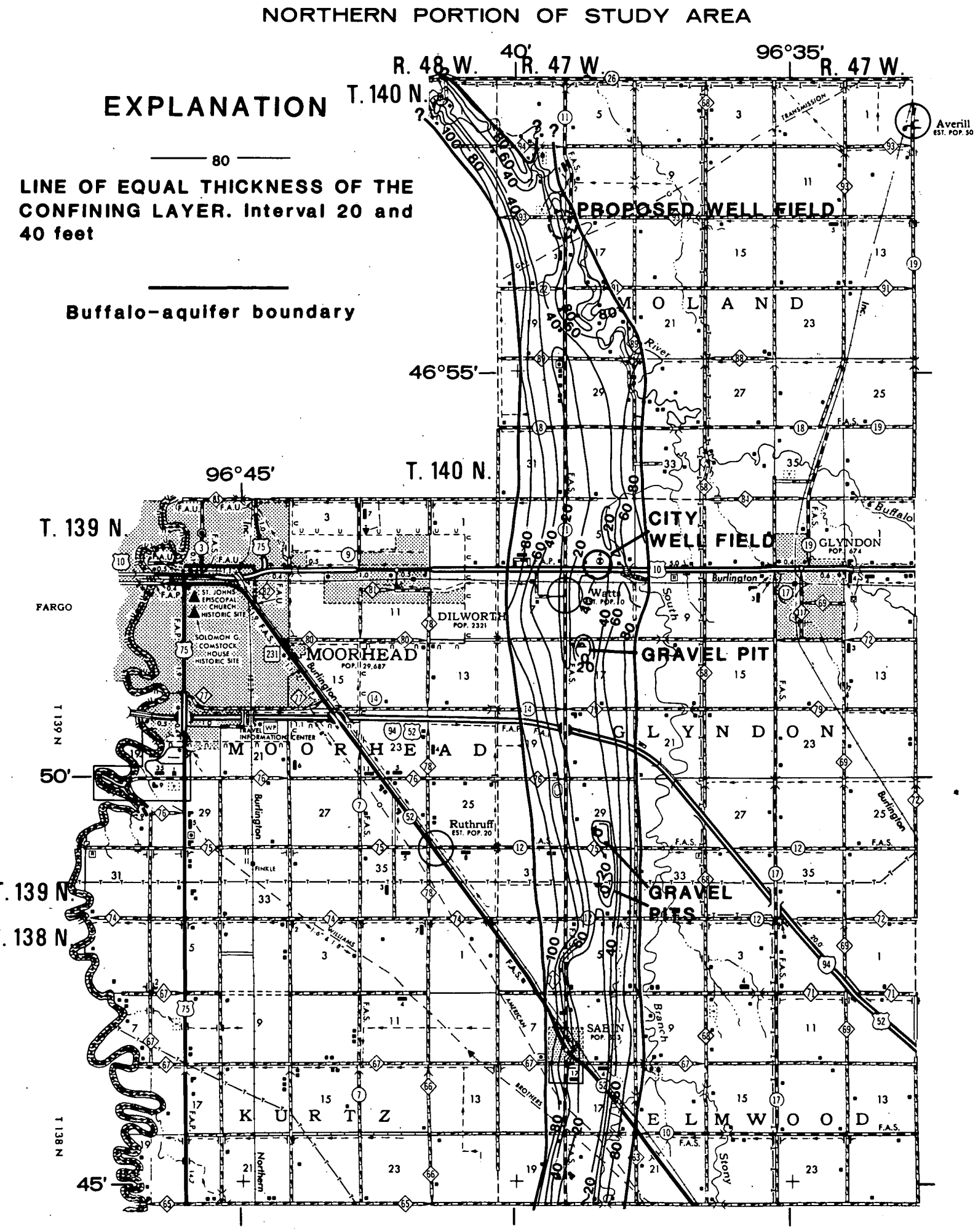

Flgure 16.--Thlckness of lake sediments 
SOUTHERN PORTION OF STUDY AREA
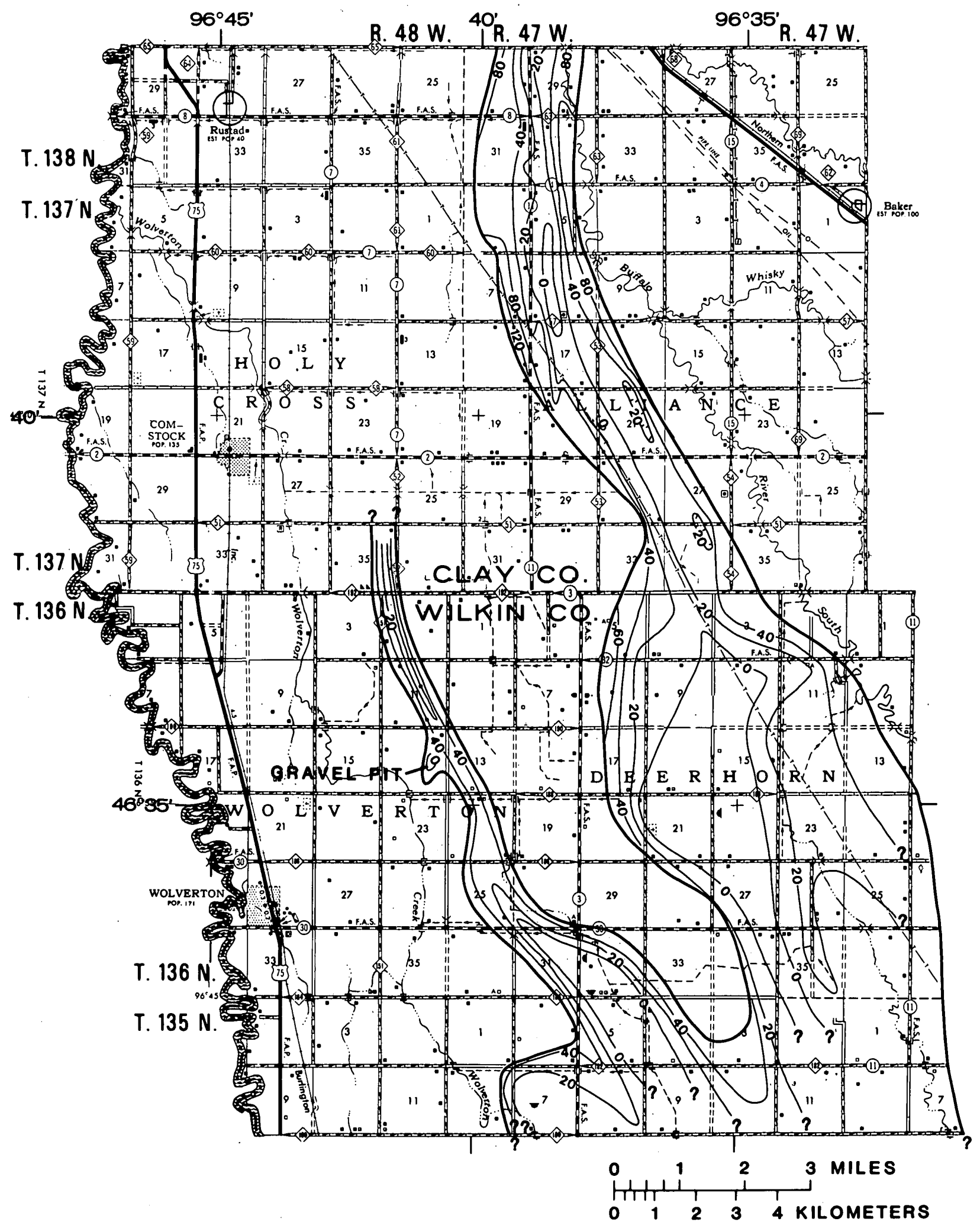

overlying the Buffalo aqulfer 
NORTHERN PORTION OF STUDY AREA

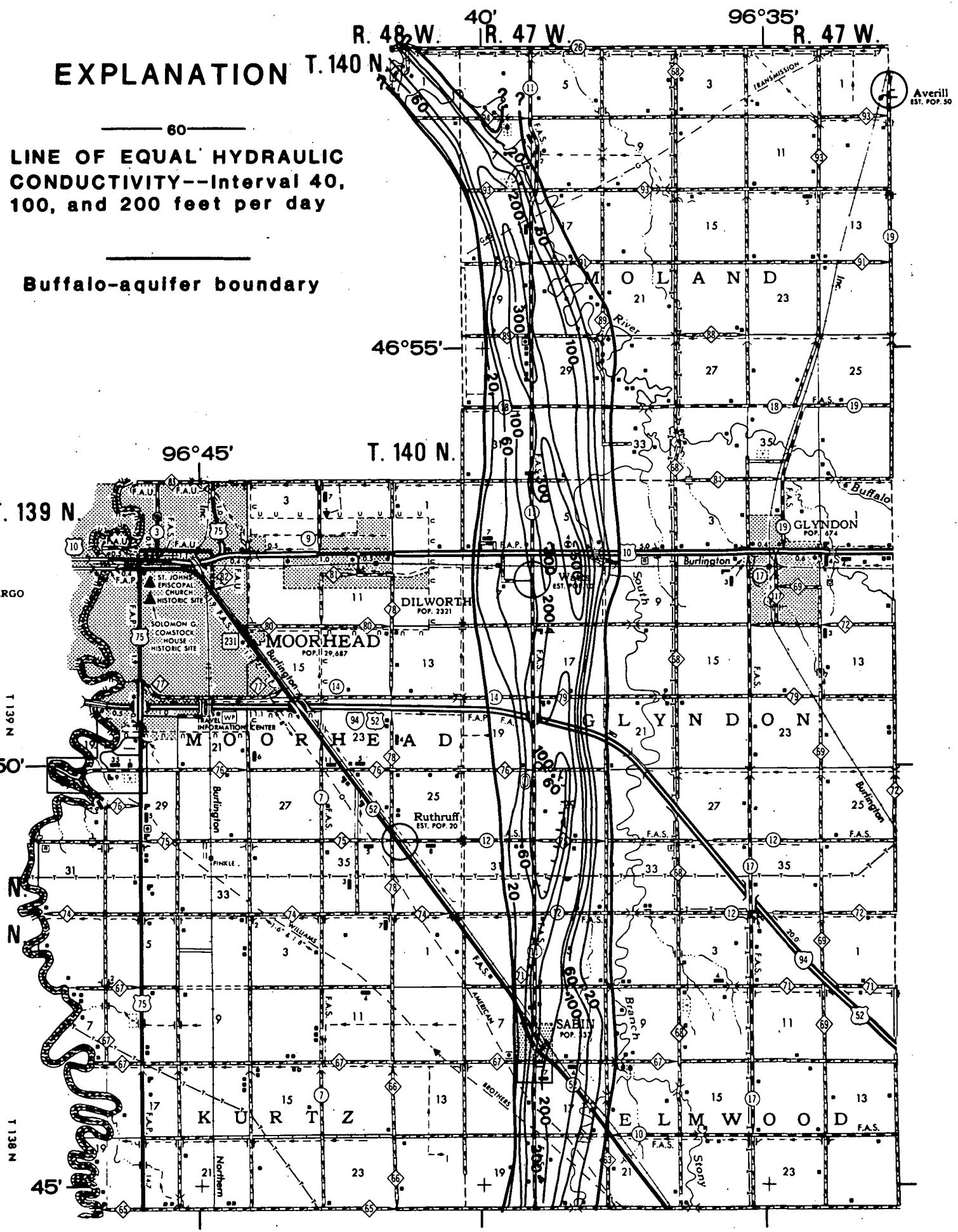

Flgure 17.--Hydraulle conductivity 


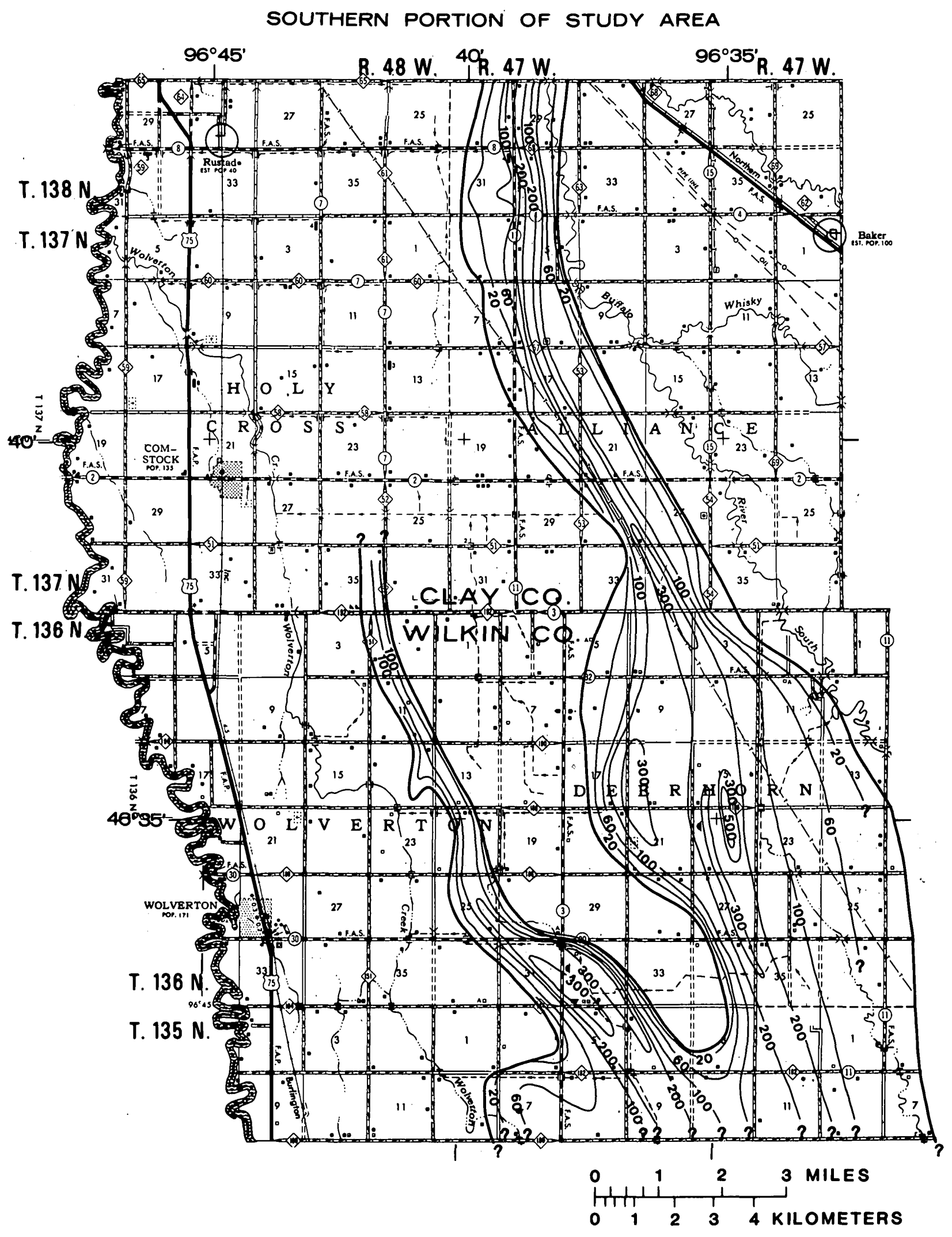

öf the Buffalo aqulfer 
NORTHERN PORTION OF STUDY AREA

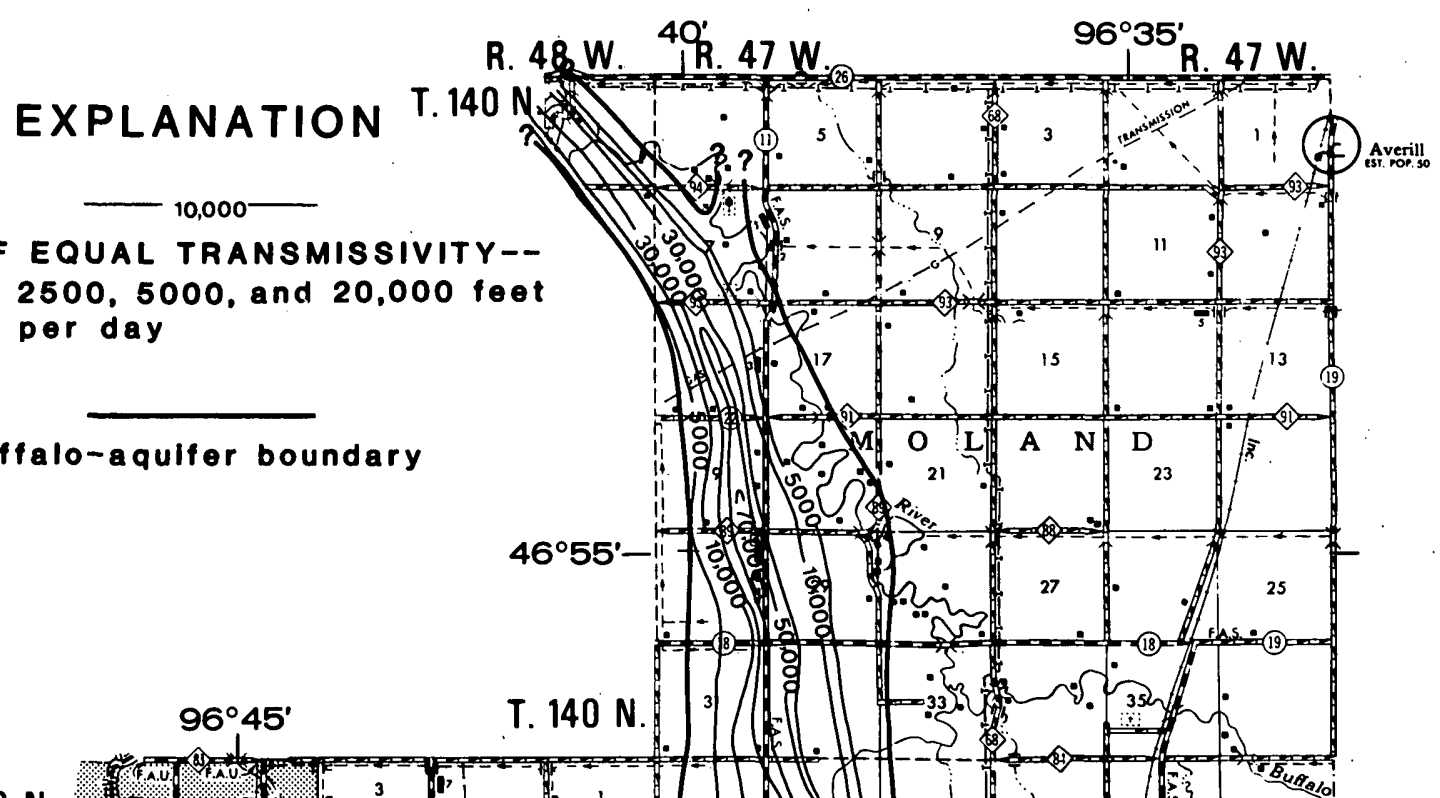

LINE OF EQUAL TRANSMISSIVITY-Interval 2500, 5000, and 20,000 feet equared per day

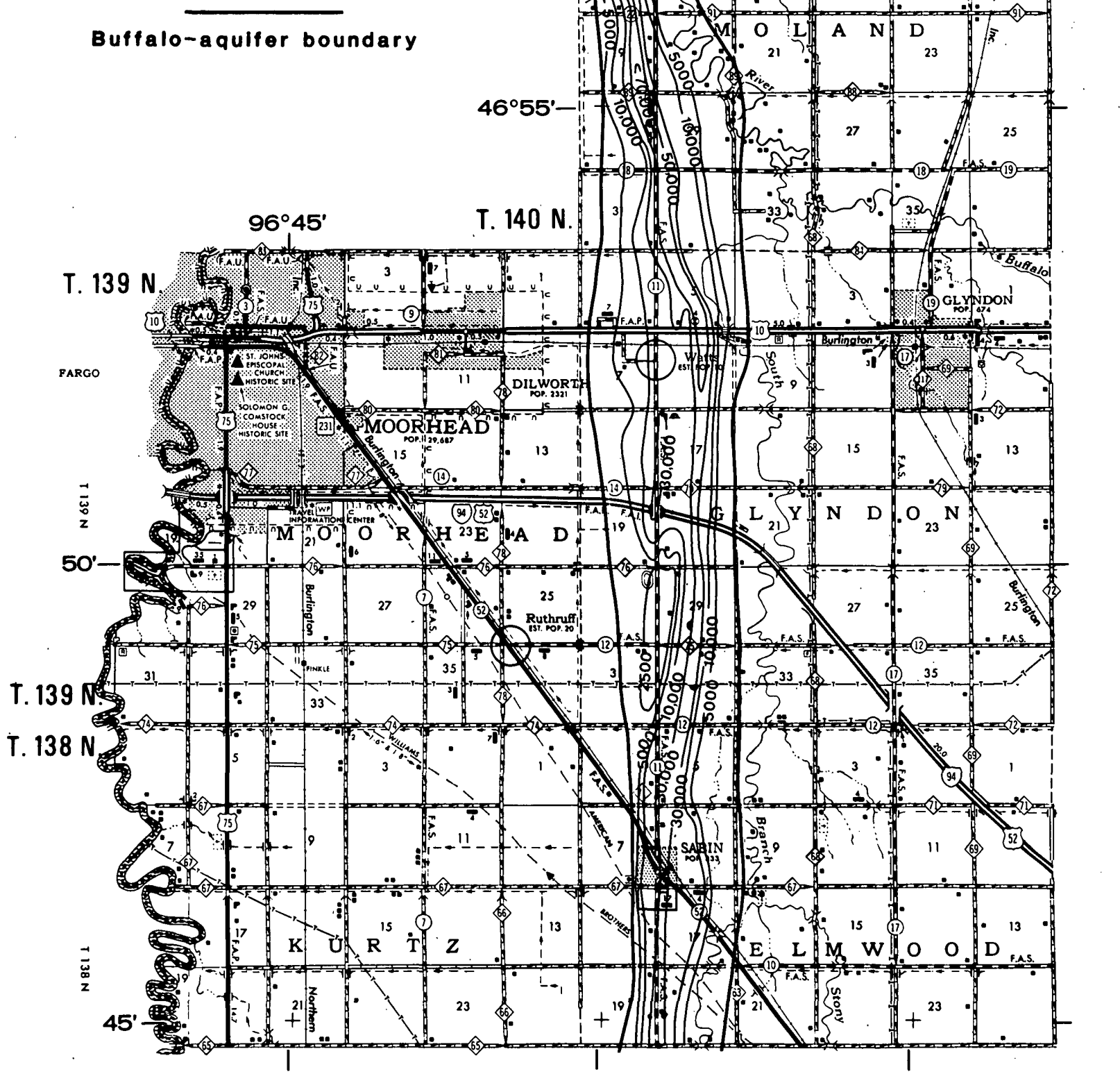

Figure 18..-Transmissivity 
SOUTHERN PORTION OF STUDY AREA

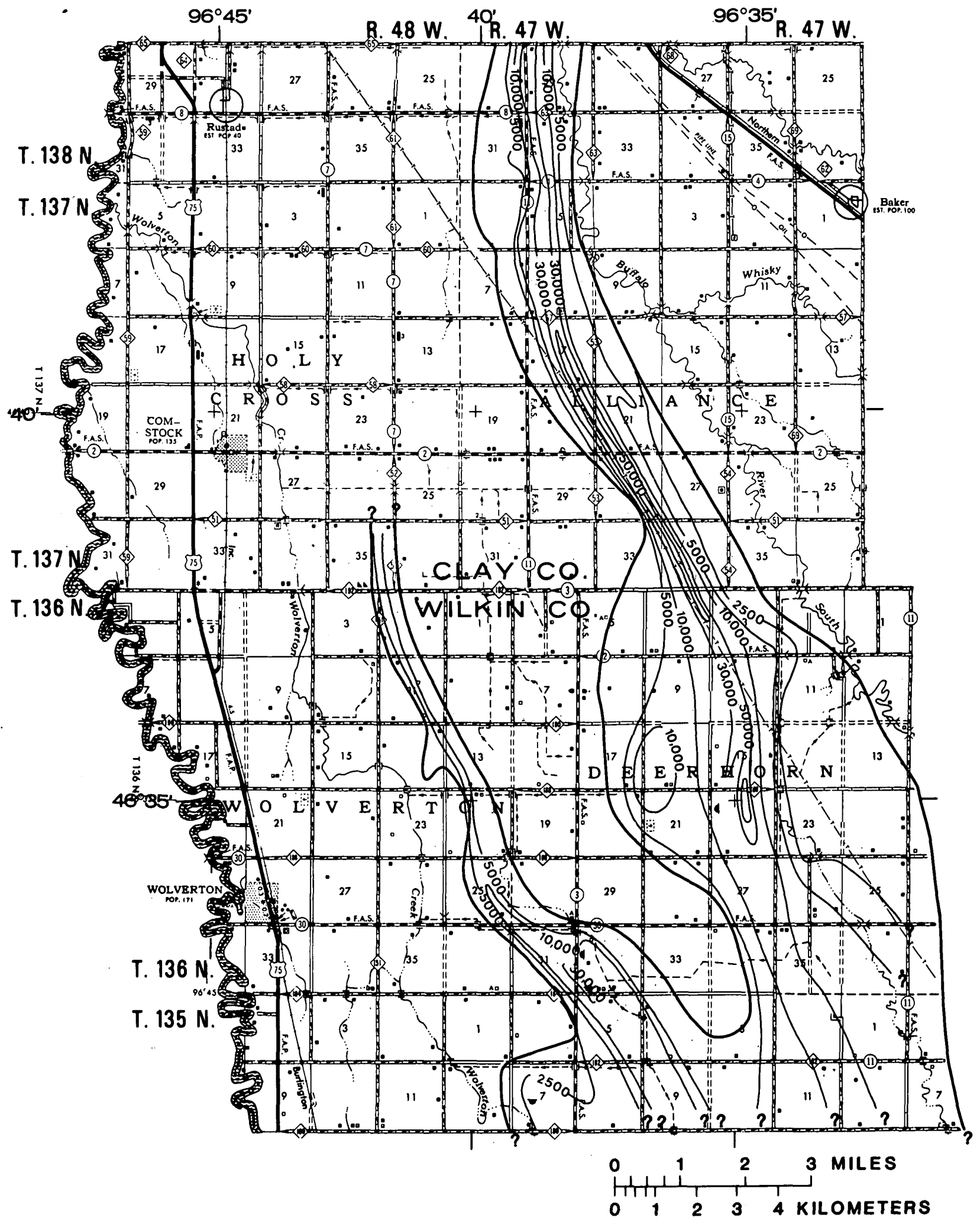

of the Buffalo aqulfer 


\section{NORTHERN PORTION OF STUDY AREA \\ R. 48,40}

EXPLANATION

T. $140 \mathrm{~N}$

500

LINE OF EQUAL THEORETICAL MAXIMUM

YIELD--Assuming a pumping perlod of 30

days and a maximum drawdown equal to

two-thirds of the saturated thickness.

Interval variable, in gallons per minute

Buffalo-aquifer boundary

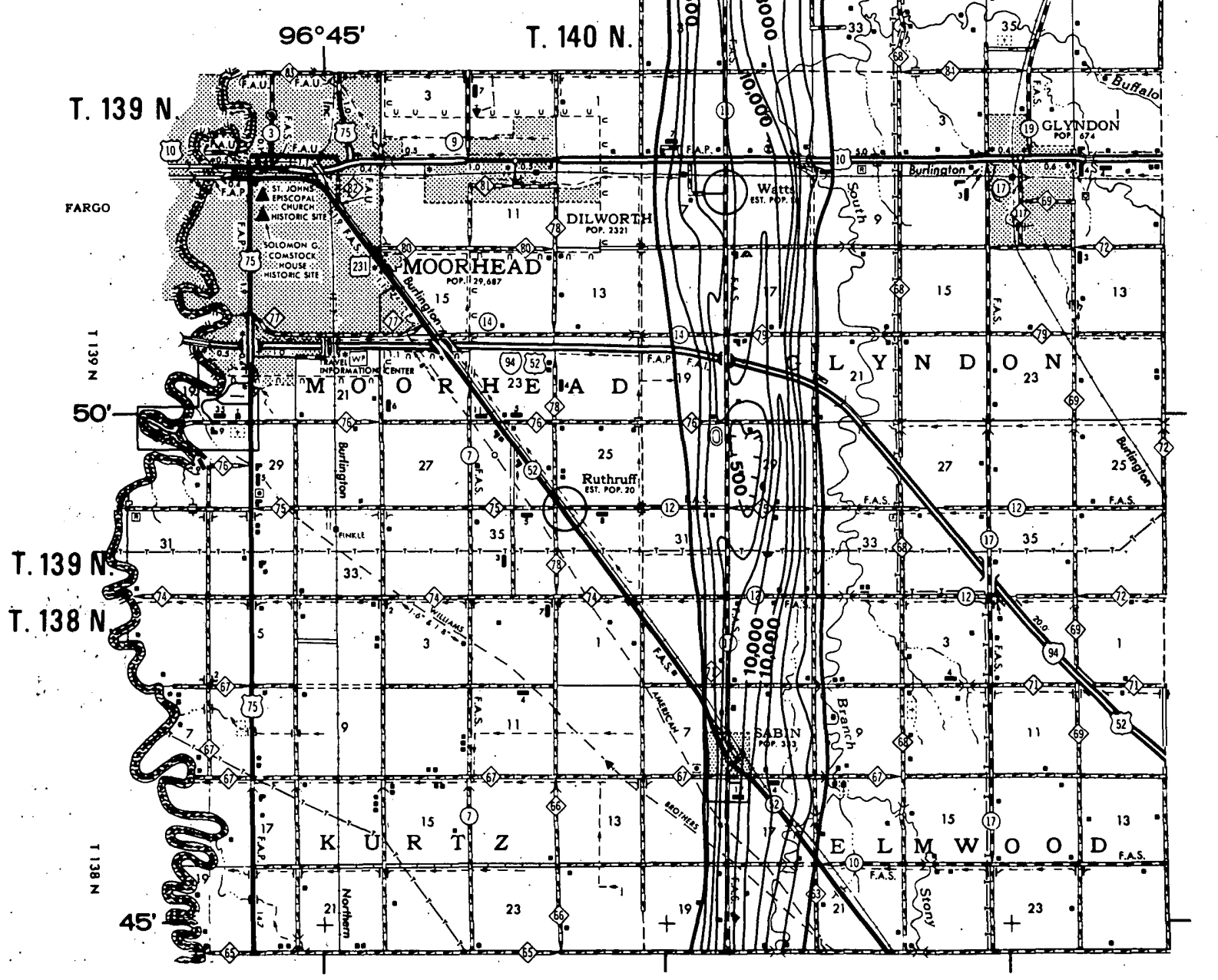

FIgure 19.--Theoretlcal maximum short-term ylelds. 


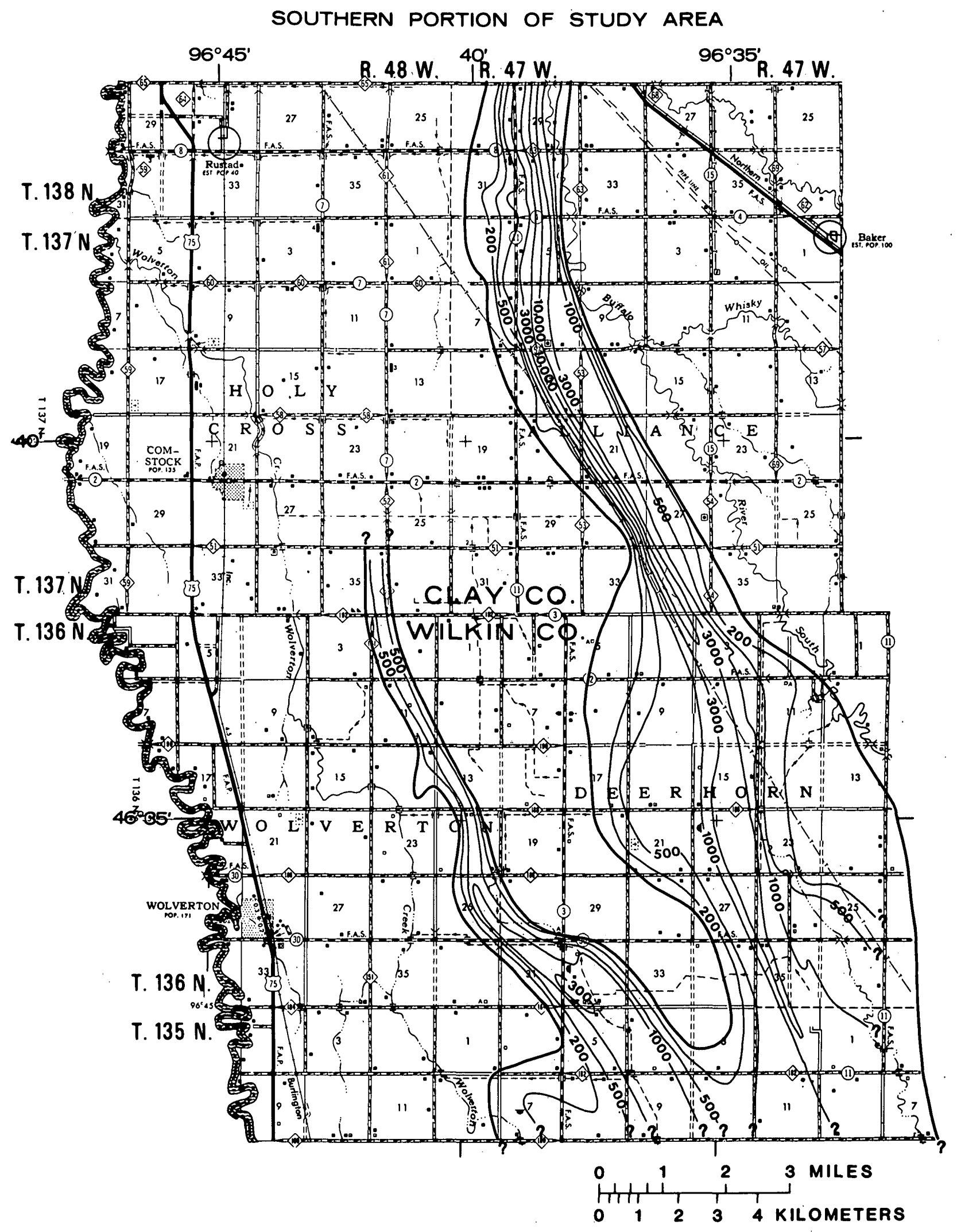

to wells completed In the Buffalo aqulfer 
however, on the basis of similar geologic and hydrologic conditions. Each test-hole $\log$ was evaluated, and hydraulic-conductivity values were assigned based on grain size and sorting of aquifer material.

The transmissivity of the Buffalo aquifer was calculated by summing the products of the saturated thickness of each lithologic unit (fine sand, medium sand, coarse sand, or gravel), as described in the well or test-hole $\log$, and the hydraulic conductivity. Hydraulic-conductivity values used for each lithologic unit were virtually those used by Helgesen (1977) for glacial outwash near Park Rapids, Minn., and are probably representative of the sand and gravel of the Buffalo aquifer. This sum of products, which equals the transmissivity of the aquifer at that point, was divided by the total saturated thickness to give the average hydraulic conductivity.

Contours of the average hydraulic conductivity at test holes and pumping-test sites are shown in figure 17. Through the use of test-hole logs and measured water levels, saturated thickness was also mapped (fig. 8). A transmissivity map ( $\mathrm{fig}$. 18) was made by combining the average hydraulic-conductivity map and the saturated thickness map. The transmissivity. and saturated thickness maps together with assumptions of pumping 30 days and maximum drawdown equal to two-thirds of the saturated thickness were used to produce the map of maximum theoretical yields of wells (fig. 19).

\section{Ground-Water Movement}

Ground water moves under the force of gravity in the direction of the head gradient. The head distribution depends on the relationship between recharge, discharge, and hydraulic conductivity. Generally, aquifers are recharged in uplands and discharged in lowlands.

The predominant direction of regional ground-water movement in the Buffalo River watershed is westward from the hummocky moraine to the lowlying valley of the Red River of the North. Water moves downward from uplands to the deeper part of the ground-water reservoir, then laterally downgradient toward valleys and depressions, where it is discharged locally by springs, seeps, and evapotranspiration. Much of the water moving from the moraine is discharged along the base of the moraine, but the rest continues to move slowly westward through the deeper part of the ground-water reservoir to the area near the Red River where it moves upward and is discharged. Within the lake plain, the water table fluctuates in response to local recharge; however, this recharge generally does not enter the deeper part of the ground-water reservoir.

Recharge to the the Buffalo aquifer is large in Wilkin County, where the aquifer is at land surface. Elsewhere, the aquifer is locally recharged by leakage through the confining layer of lake sediments and through the underlying clayey till. The direction of ground-water flow is northward. 
Most of the discharge from the Buffalo aquifer is probably to the Buffalo River and South Branch Buffalo River. Although the streams are not directly connected to the aquifer, water from the aquifer discharges through the confining layers of silt and clay in response to head differences between the aquifer and the stream. Data show that the head in the aquifer is generally above the head in the stream except in the vicinity of the Moorhead city well field, where the reverse prevails. Heads in the confining layer, which are necessary for understanding movement of water through the confining layer, are largely unknown.

\section{Recharge}

The source of recharge to the Buffalo aquifer is mainly snowmelt and rain in spring and, occasionally, rain in autumn. Most of the rain that infiltrates the soil during summer is evaporated or transpired.

Recharge is greatest where the aquifer is unconfined. These areas are most extensive in Wilkin County, but also occur along the length of the aquifer, where it is at or near 1 and surface. These unconfined areas are shown in figure 20.

Hydrograph analysis is useful in delineating areas of recharge. Hydrographs of observation wells in water-table areas show a distinctive pattern of steep water-level rises, sharp peaks, and relatively rapid declines in response to recharge. In contrast, hydrographs of observation wells in the confined area show gradual rises and declines, resulting in low, rounded peaks that lag behind recharge to the surficial deposits. Examples of these patterns of water-level fluctuations are shown in figure 21.

Recharge during 1977-78 was determined from hydrographs of 18 watertable observation wells. Location of the observation wells is shown in figure 20. Computation of annual recharge is shown on an example hydrograph in figure 22. Computed recharge ranged from 2.4 inches to 9.9 inches and averaged 4.1 inches per year at the observation wel1s. Recharge computed from 1965-78 records for one well ranged from 2.4 to 8.8 inches and averaged 4.7 inches per year compared with 4.9 inches per year for the 1977-78 records alone. Climatic records suggest that the quantity of recharge derived from 1977-78 precipitation may be considered above average with respect to the 1941-70 normal monthly precipitation.

Although recharge is largest in the water-table areas, leakage through the overlying confining bed of lake sediments also contributes to recharge. Leakage is undoubtedly small locally, but, because it occurs over large areas, the total volume can be sizable. Leakage to the aquifer depends on (1) head difference between the water table within the overlying leaky confining bed and the potentiometric surface of the aquifer, (2) vertical hydraulic conductivity of the confining bed, and (3) thickness of the confining bed. 
NORTHERN PORTION OF STUDY AREA

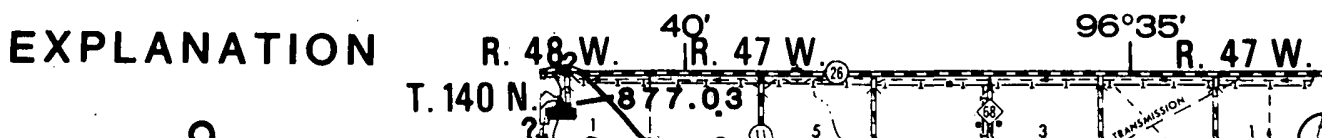

\subsection{3}

OBSERVATION WELL IN BUFFALO AQUIFER--

Number is altitude of potentlometric level.

Datum is NGVD of 1929

\$04.25

STREAM-STAGE MEASURING SITE--Number I8 altitude of Buffalo River and South Branch Buffalo River. Datum is NGVD of 1829

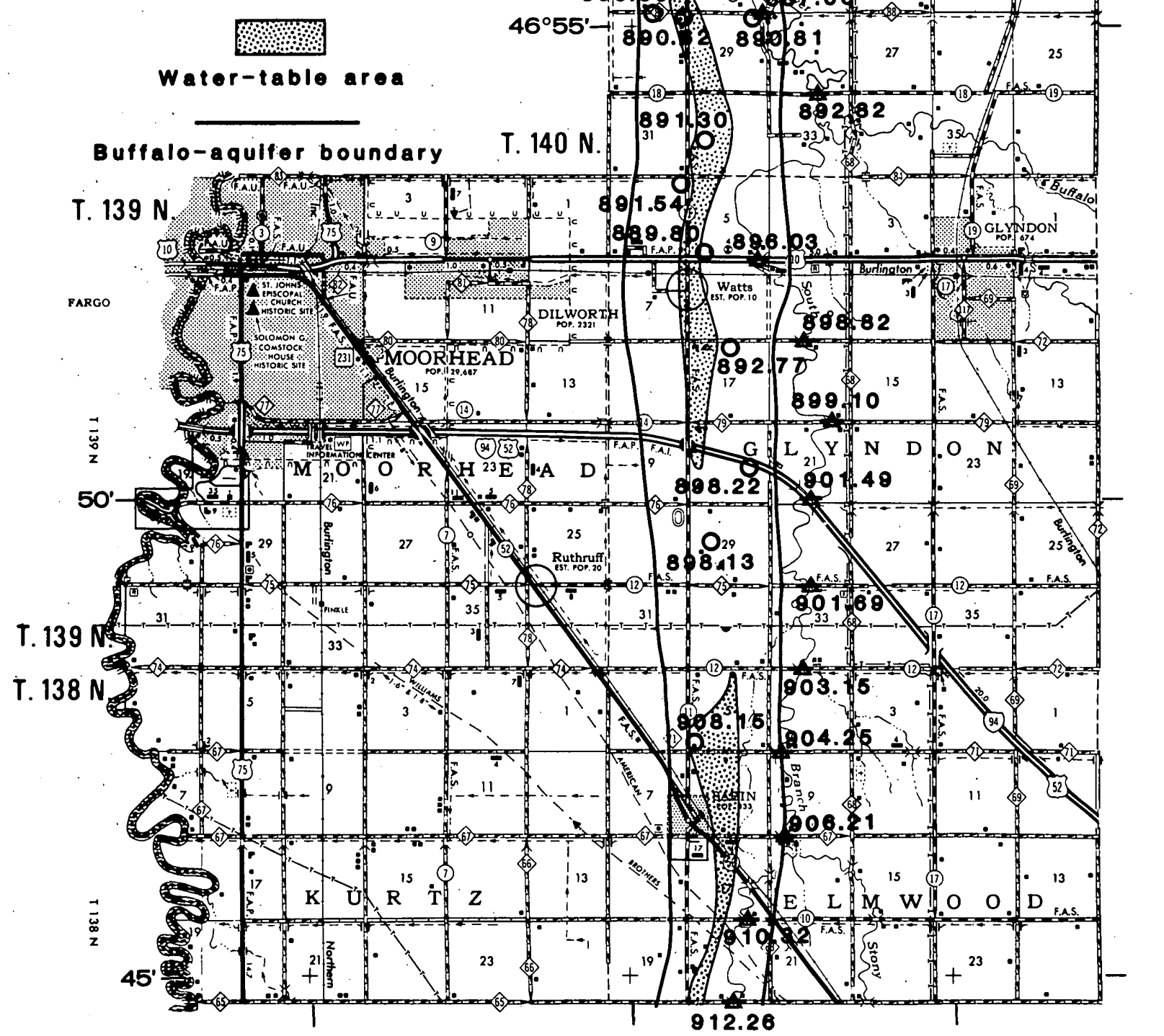

FIgure 20.--Location of measuring sites and altitudes of water streams; September 27, 1978 


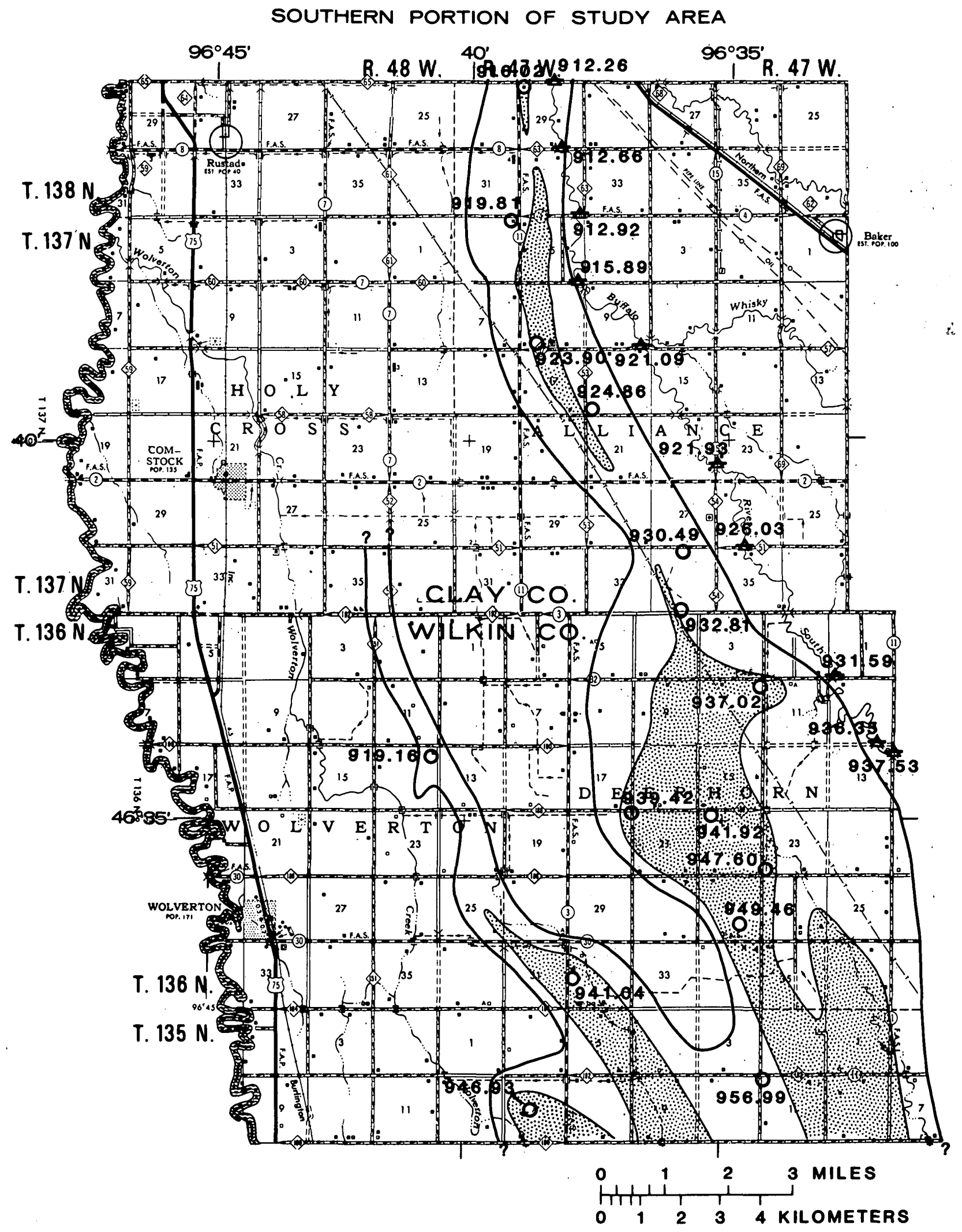

levels in the Buffalo aquifer, overlying confining layer, and nearby 


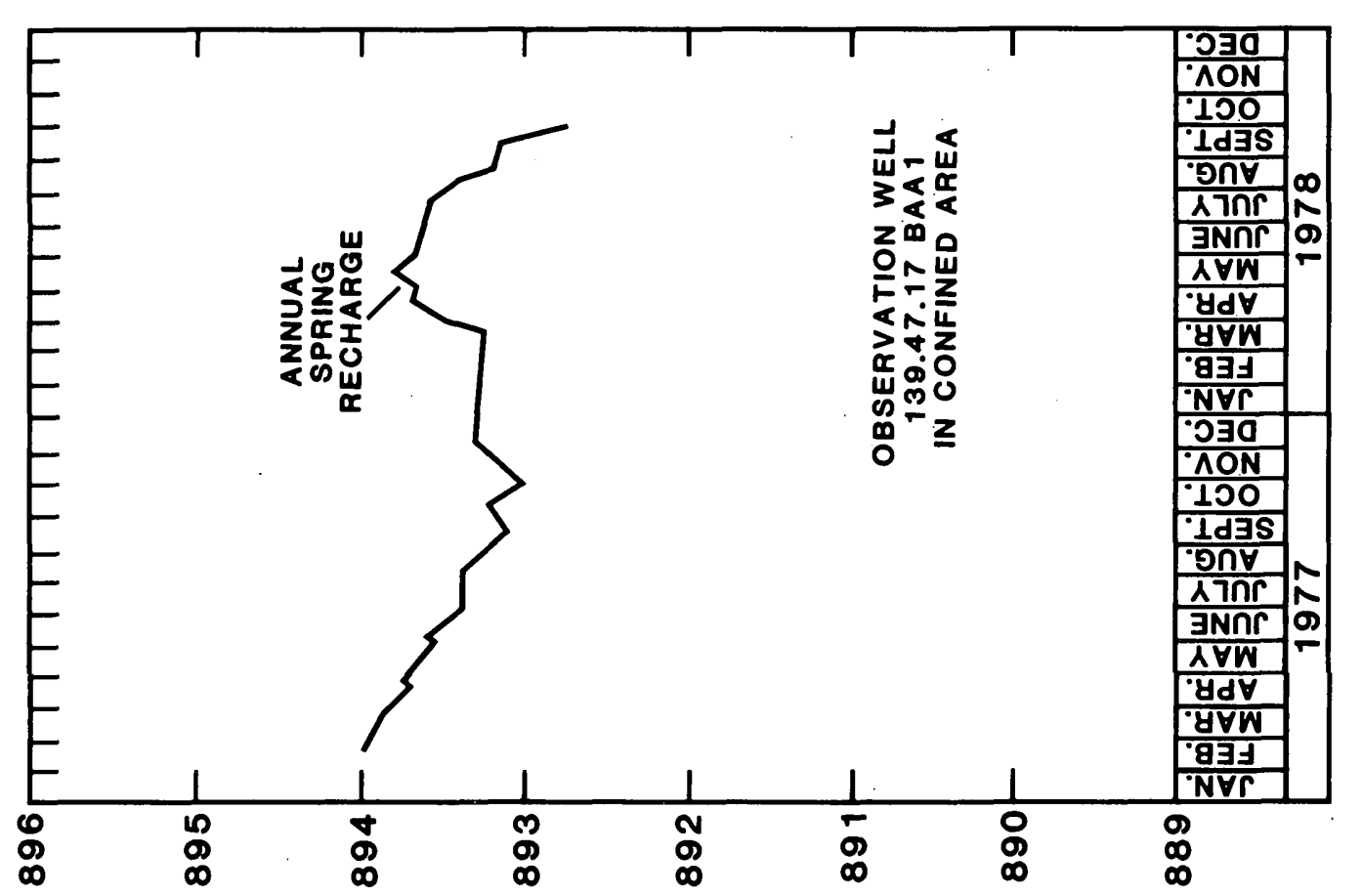

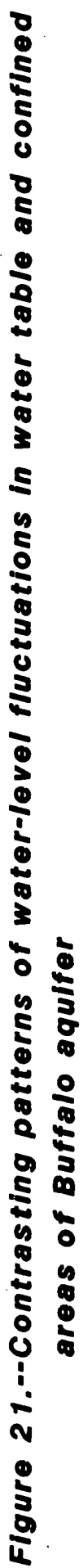




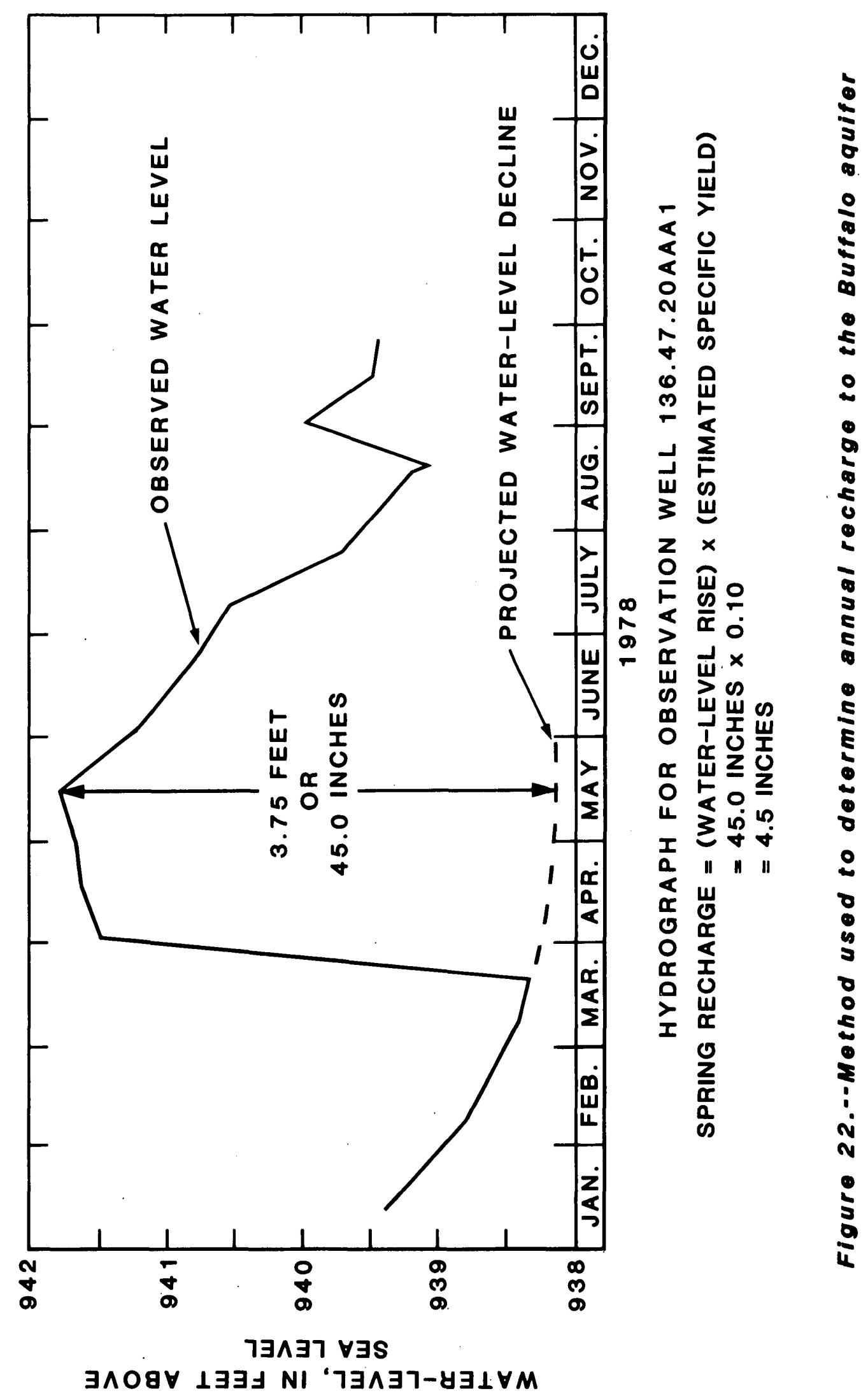


The underlying till may also leak water upward. Again, the leakage may be small, but because it occurs over large areas the total volume can be sizable. The relation between upward leakage and increased concentration of chemical constituents is discussed in the section on water quality.

\section{Discharge}

The Buffalo aquifer is discharged primarily through the surrounding lake sediments to the Buffalo River and the South Branch Buffalo River and secondarily through the lake sediments to the Red River of the North. Evapotranspiration directly from the Buffalo aquifer is negligible, except locally from the few gravel pits that intercept the water table.

Pumpage accounts for a part of the discharge from the aquifer mostly from the Moorhead city well field. A few irrigation wells pump during the growing season, especially in dry years. Rural domestic and stock wells withdraw small amounts. The effect of pumpage from the Moorhead well field on water levels is shown in figure 23. Pumpage was apparently exceeding recharge until pumpage was reduced in the early 1960's, when the city began using the Red River as a primary source of water. The steady decline of water levels was reversed and then leveled off during the late 1960's and 1970 's.

\section{Ground-Water Surface-Water Relationships}

Water in a stream is intimately related to water moving through the aquifer beneath and adjacent to the stream. Water is interchanged between stream and aquifer, depending upon many factors, among which are: (1) thickness and vertical hydraulic conductivity of the streambed and (2) head differences between aquifer and stream. The net movement of water between the Buffalo aquifer and adjacent streams is to the stream; thus, groundwater discharge sustains streamflow, which is termed base flow.

Test drilling in the vicinity of the Buffalo and South Branch Buffalo Rivers indicated that the streams are generally indirectly connected to the Buffalo aquifer. Less permeable lake sediments ranging from less than 20 feet thick locally to 100 feet thick separate the stream and aquifer, as shown by the hydrogeologic sections (figs. 10 to 15) and the contoured testhole data (fig. 16).

The profile of one set of water-level measurements (October 24, 1977), made at the same time as base-flow measurements, is shown in figure 24. Comparison of the potentiometric surface of the Buffalo aquifer with the adjacent stream profile indicates that the direction of movement of ground water, except near the Moorhead well field, is mostly from the aquifer to the stream. Before the aquifer was developed, the gradient between the aquifer and the adjacent stream was toward the stream except for brief periods during floods. In 1947, water levels in the aquifer were 9 feet 

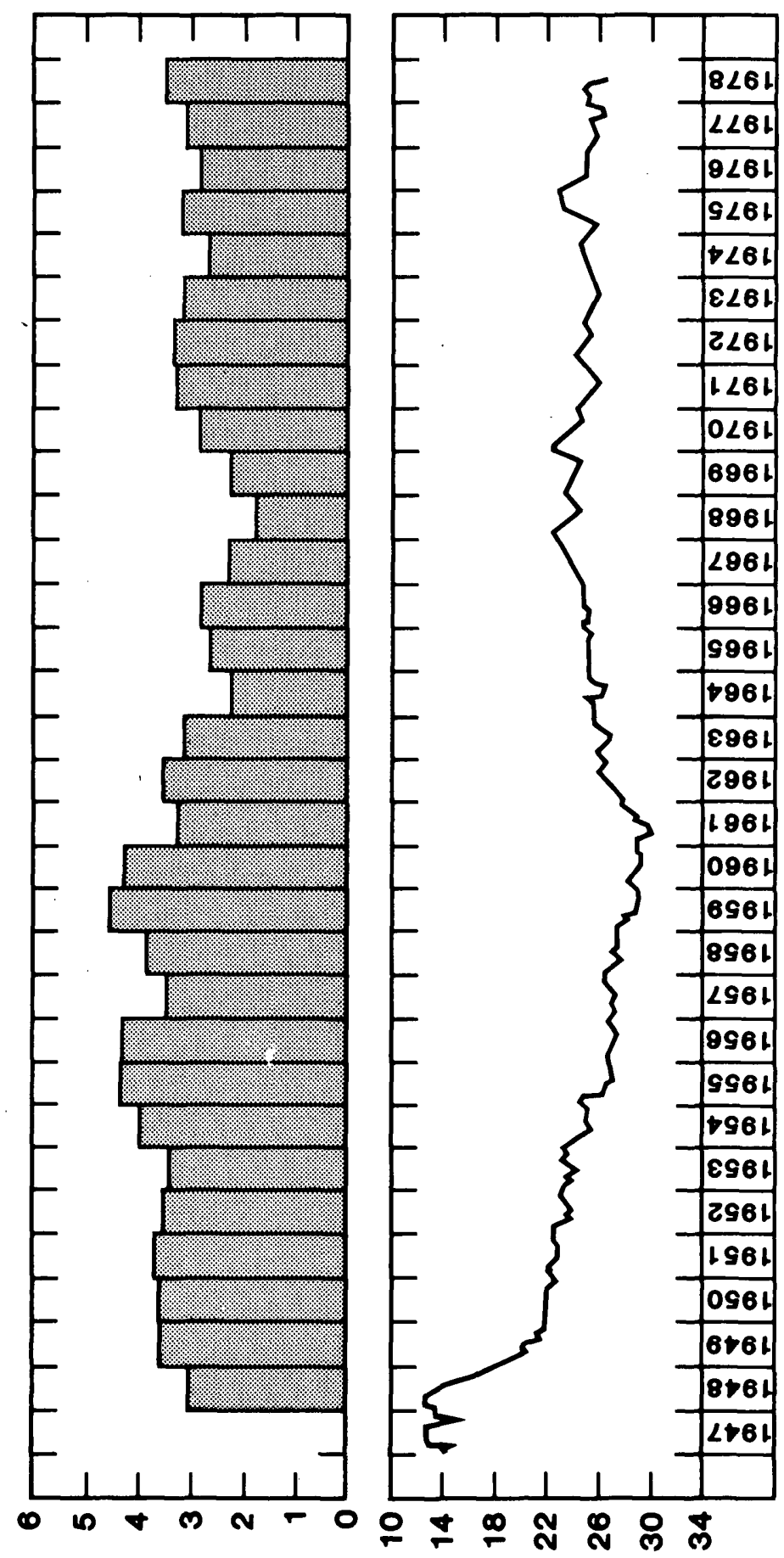

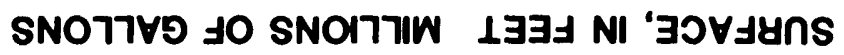

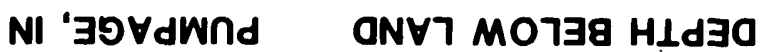

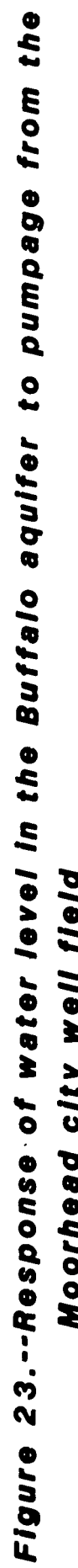




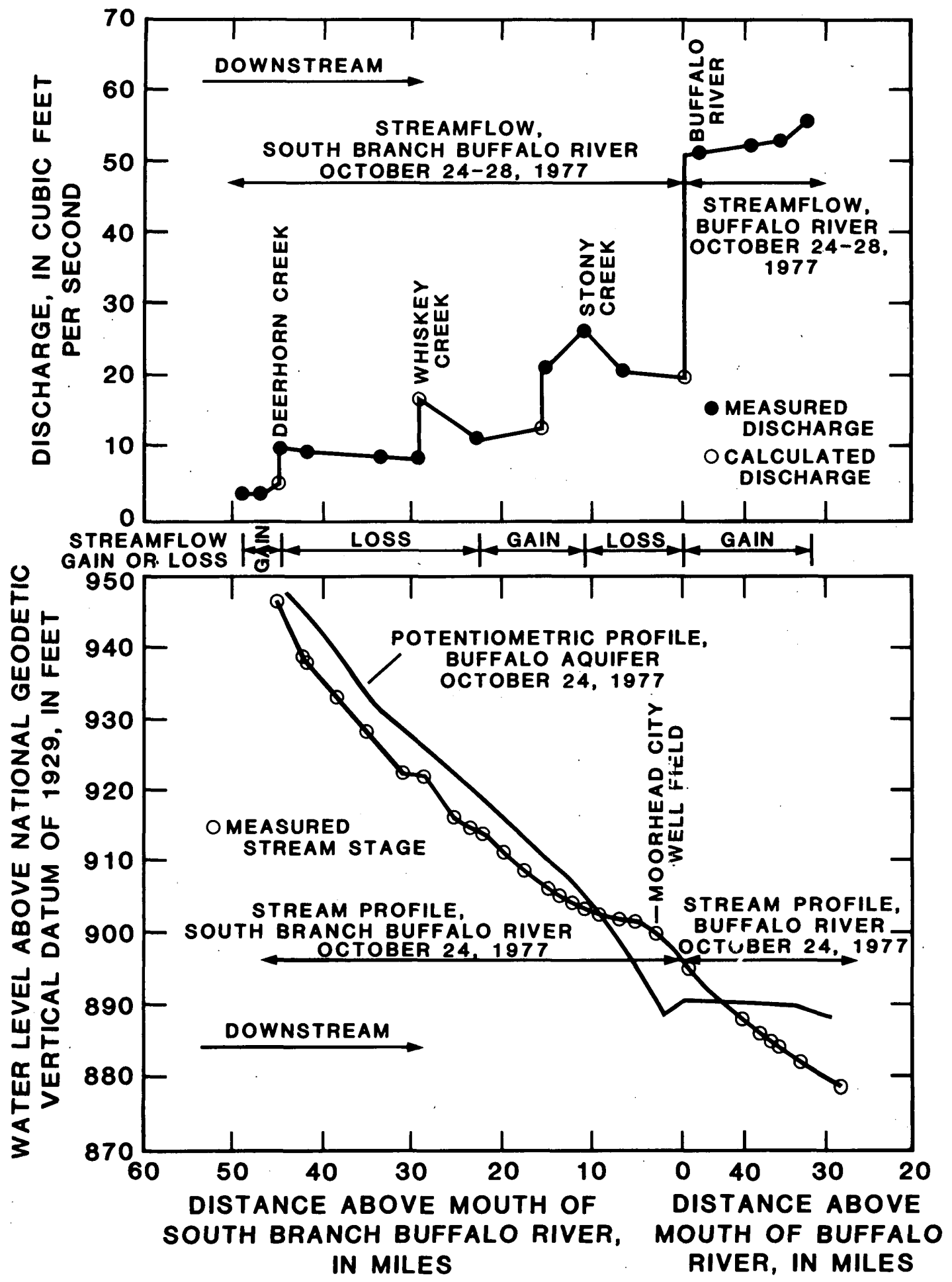

Figure 24.--Graphs comparing the potentiometric profile of the Buffalo aquifer with stream proflle and flow of the adjacent streams at low flow 
above average river stage in the area where Highway 10 crosses the South Branch Buffalo River and 5.5 feet above average river stage 14 miles south of the highway (U.S. Geological Survey file data, 1947).

Base-flow measurements at or near the same time along a stream are used to evaluate the interrelations of streamflow and ground water. Three sets of base-flow measurements were made along those parts of the two Buffalo Rivers adjacent to the Buffalo aquifer.

The first set of measurements was made in November 1976, when the stream was at 93 percent duration flow near Dilworth and at 66 percent duration flow at Sabin. These low flows were related to the 1976 drought. As shown in figure 25, the measurements indicated many losing and no-flow reaches, especially along the South Branch Buffalo River and its tributaries. Some of these no-flow reaches may be attributed to ice storage or storage behind beaver dams.

The second set of measurements was made in April 1977 (fig. 25) at about 30 percent duration flow near Dilworth and about 18 percent duration flow at Sabin after the unusually small peak spring runoff for 1977 . This set of measurements indicates a gaining stream except for two reaches of neither gain nor loss that generally correspond to the losing reaches along the South Branch Buffalo River shown by the October 1977 measurements.

The third set of base-flow measurements shows the relationship of discharge and river-mile distance of the October 1977 set of streamflow measurements (fig. 24) and the gaining and losing reaches of the stream. This set of measurements, made at approximately 40 percent duration flow at Dilworth and approximately 30 percent duration flow at Sabin, included more closely spaced measuring sites than the earlier sets and included measurements of the main tributaries. This seepage run shows an 11-mile losing reach along the South Branch Buffalo. River downstream from Sabin, which can be attributed, at least in part, to induced infiltration through the streambed and lake sediments to the Moorhead city well field. The measurements also indicate another losing reach of the South Branch Buffalo River approximately 22 miles long from Deerhorn Creek downstream past Whiskey Creek. With in the reach, flow decreased 19 percent from Deerhorn Creek to Whiskey Creek and 30 percent from Whiskey Creek to the next measuring site about 5 river miles downstream. This losing reach cannot be explained by losses to the aquifer because the head in the aquifer is higher than the stream level. More closely spaced stream-discharge measurements would probably indicate an intricate pattern of gains and losses throughout this reach, whereby water is interchanged between the stream and permeable zones in the lake deposits such as old stream channels, meanders, or oxbows that "shortcircuit" the channel. Some of the losses may also be due to storage of water in wetlands and behind beaver dams or, in part, to measurement errors. 

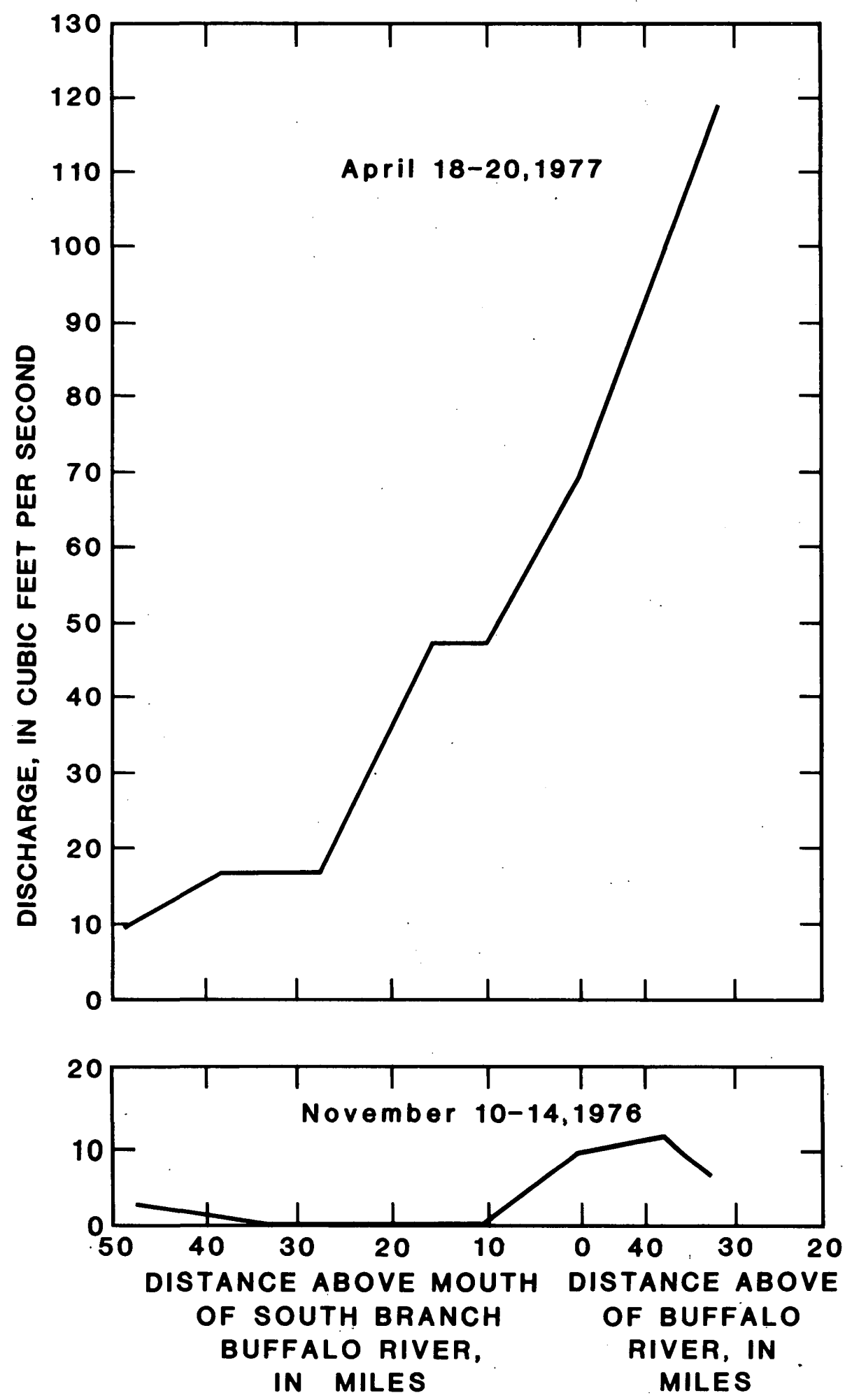

Figure $25 .--F l o w$ of the South Branch Buffalo River and Buffalo River, Aprll 18-20, 1977 and November 10-14, 1976 


\section{Ground-Water Availability}

Water availability to wells depends on many factors. The presence of an areally extensive, thick, permeable aquifer with much storage capacity is essential. Abundant precipitation is necessary to supply adequate recharge to sustain pumpage. The presence of an adjacent or overlying stream sufficiently interconnected with the aquifer to allow induced stream infiltration greatly enhances water availability from an aquifer.

\section{Water in storage}

The Buffalo aquifer has 270 billion gallons of water (estimated) stored in its mapped $32-\mathrm{mil}$ e length. This estimate is based on the saturated thickness map ( $\mathrm{fig} .8$ ) and an estimated average porosity of 30 percent for the outwash aquifer. In 1947, about 50 billion gallons of water was stored in the then-known part of the aquifer extending 15 miles south of Highway 10 (U.S. Geological Survey file data, 1947). New test drilling and mapping indicates that the aquifer is thicker and more permeable than previously known and that approximately 100 billion gallons of water is stored in that $15 \mathrm{mile}$ length of the aquifer south of Highway 10 .

Not all ground water in storage can be withdrawn by wells. Some is retained against gravity in intergranular pore spaces by capillary action even after water levels are lowered by pumping. The quantity of water that could be derived from gravity drainage, termed specific yield, generally ranges from 10 to 20 percent of the volume of the aquifer.

From a practical standpoint, it is impossible to pump water levels evenly to the bottom of an aquifer. Even if it were possible, effects would be adverse, such as the dewatering of many older, shallower wells in the aquifer and the reduction or cessation of streamflow by interception of ground water that formerly discharged to the stream.

The quantity of water that could be withdrawn from storage in the Buffalo aquifer is approximately 120 billion gallons, assuming a specific yield of 0.2 , no recharge, and an even lowering of water levels by twothirds of the saturated thickness over the entire area. Theoretical well yields associated with such a dewatering scheme have been mapped and are discussed in the following section. Because the simplifying assumptions necessary for the calculations are not and could never be met, actual yields would be much less than those estimated.

\section{Theoretical maximum well yields}

The theoretical maximum yields to wells were calculated using the equation of Theis (1935) along with the following necessary assumptions and corrections:

1. Aquifer is unconfined, homogeneous, isotropic, and infinite in areal extent. 
2. Well is open to full saturated thickness of aquifer, is 12 inches in diameter, and is 100 percent efficient.

3. Specific yield is 0.20 .

4. Relationship between recharge and discharge of the aquifer during pumping remains constant.

5. Effects of hydrologic boundaries and interference between wells are negligible.

6. Pumping is continuous for 30 days, with drawdowns limited to two-thirds of the saturated thickness.

7. Drawdowns at the wells were corrected for decreasing transmissivity due to dewatering of the aquifer (Jacob, 1944).

The resultant map (fig. 19) is intended to indicate only general trends and relative differences in water-yielding capability. The map cannot be used for accurate projection of well yields at any given location because the effects of hydrologic boundaries and local variations in transmissivity and storage have not been incorporated.

The areas of maximum yield coincide with areas of highest hydraulic conductivity and saturated thickness--generally along the narrow, deep trough in the middle of the Buffalo aquifer. Examples of such highyielding wells are the irrigation wells in $\mathrm{sW}^{1} / 4 \mathrm{sec} .32$, T. $140 \mathrm{~N}$., R. $47 \mathrm{~W}$. , and SW $1 / 4 \mathrm{sec} .8, \mathrm{~T} .139 \mathrm{~N} .$, R. $47 \mathrm{~W}$. Both of these wells are usually pumped at $1,000 \mathrm{gal} / \mathrm{min}$ and have less than 10 feet of drawdown. Closely spaced (less than 500 feet) test-hole drilling is necessary to locate the trough, which has been missed in previous attempts to delineate the aquifer.

\section{Induced infiltration}

Recharge by induced infiltration from streams is a major factor in sustaining large water supplies from aquifers, especially where pumping would otherwise result in excessive drawdowns. Large withdrawals can be sustained from wells located near a stream. A benefit of induced infiltration not afforded by direct surface-water use is the chemical and biological cleansing provided by the filtering action of the aquifer material.

Recharge from the South Branch Buffalo River to the Buffalo aquifer is induced near the Moorhead city well field. Data are not available to determine the quantity of such recharge reliably, but the data indicate that the well field is not in the ideal place for maximum induced recharge. Additional test drilling could locate the ideal place. 


\section{Artificial recharge}

Some important factors affecting the use of stream water for artificially recharging an aquifer are chemical and bacteriological quality, sediment load, and temperature. These factors may vary seasonally, daily, or even hourly. Daily mean suspended-sediment concentration and daily temperature were determined for open-water periods at the gaging stations Buffalo River near Dilworth, Buffalo River near Hawley, and South Branch Buffalo River near Sabin. Data from the stations have been published by the U.S. Geological Survey $(1978 ; 1979)$. Sediment-transport curves and thermographs are presented in figures 26 and 27 , respectively, and are discussed in a later section. The relation of specific conductance and streamflow for the 1977-78 water years is shown in figures 28,29 , and 30 .

Improvement of stream-water quality and of infiltration rates through artificial-recharge ponds $c$ an be achieved by filtering the stream water before injection and by periodic drying and tilling of the pond bottom. However, contaminants dissolved in the recharge water would be introduced directly into the aquifer unles's the water were treated chemically to remove such contaminants before infiltration.

The best locations for recharge ponds in the Buffalo aquifer are generally along the centerline of the aquifer where the saturated thickness and transmissivity are large and where the overlying confining layer is thinnest. These locations $c$ an be found by comparing figures 8,16 , and 18. Some of these places are along a line trending slightly northwestsoutheast near the half section line of sec. 32, and just east of the west section line (County Road 11) of sec. 29, and extending through $E^{1 / 2 E^{1} / 2}$ $\mathrm{SE}^{1} / 4 \mathrm{sec} .19$, T. $140 \mathrm{~N} ., \mathrm{R} .47 \mathrm{~W}$.

\section{Numerical Model for Aquifer Evaluation}

A two-dimensional finite-difference areal (horizontal flow) steadystate numerical model was used to simulate flow in the Buffalo aquifer. The model was developed by Pinder and Bredehoeft (1968) and revised by Trescott and others (1976). The purpose of modeling the Buffalo aquifer was to gain an understanding of the ground-water-flow system.

Measured water levels shown in figure 20 were assumed to be representative of steady-state conditions in the Buffalo aquifer. Model results were then compared with these water levels as a test of modeled versus real-world conditions. First attempts to approximate the measured water levels were made by applying uniform recharge over the entire modeled area. This was followed by varying recharge areally, which consisted of applying (1) a relatively large recharge rate from precipitation in the water-table areas, (2) a relatively small recharge rate simulating leakage where the overlying confining bed is thin, and (3) a very small recharge rate where the confining bed is thick. Hydraulic-conductivity values were also changed within 


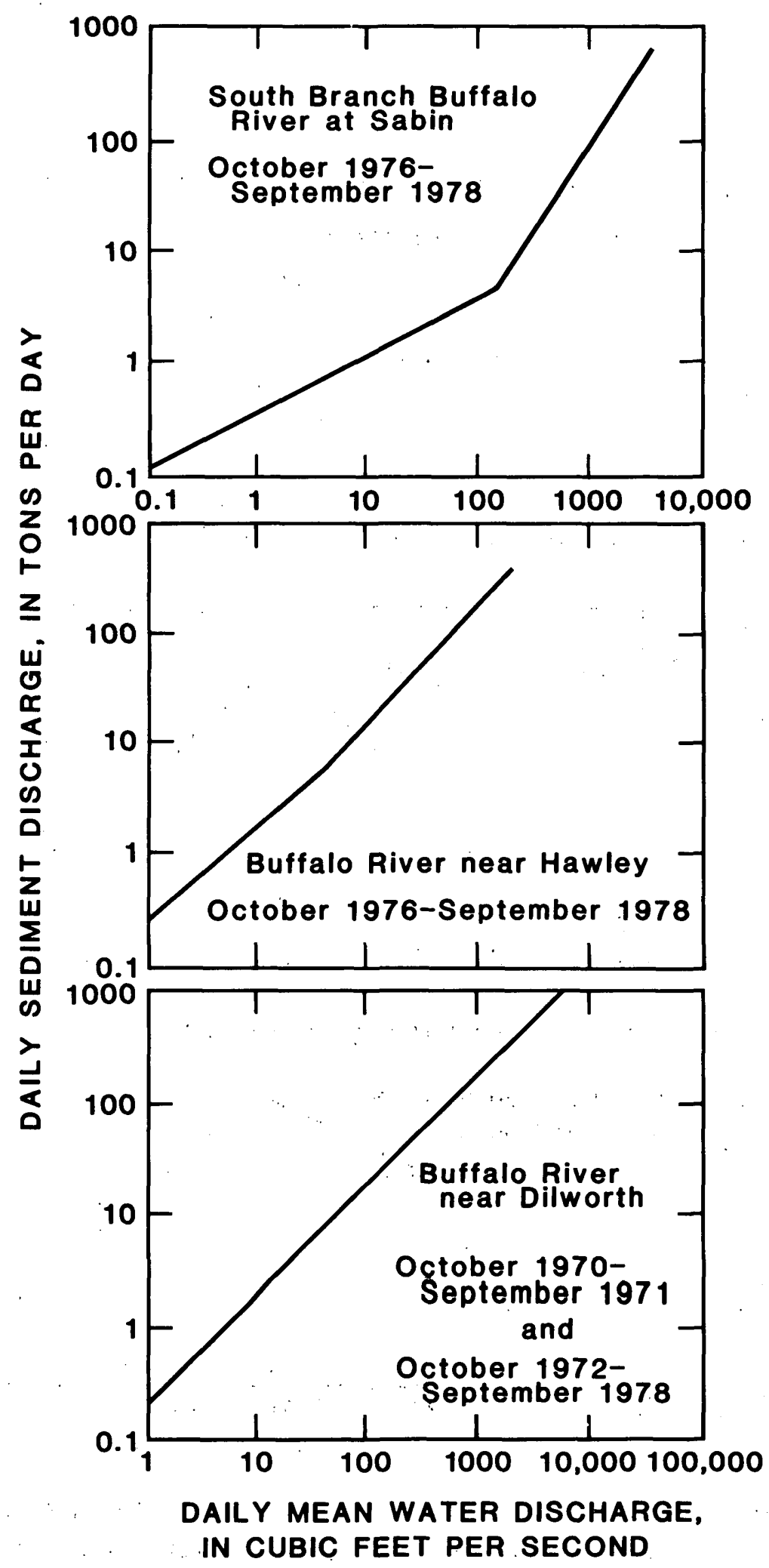

Figure 26.--Sediment-transport curves for sediment stations in the Buffalo RIver watershed 


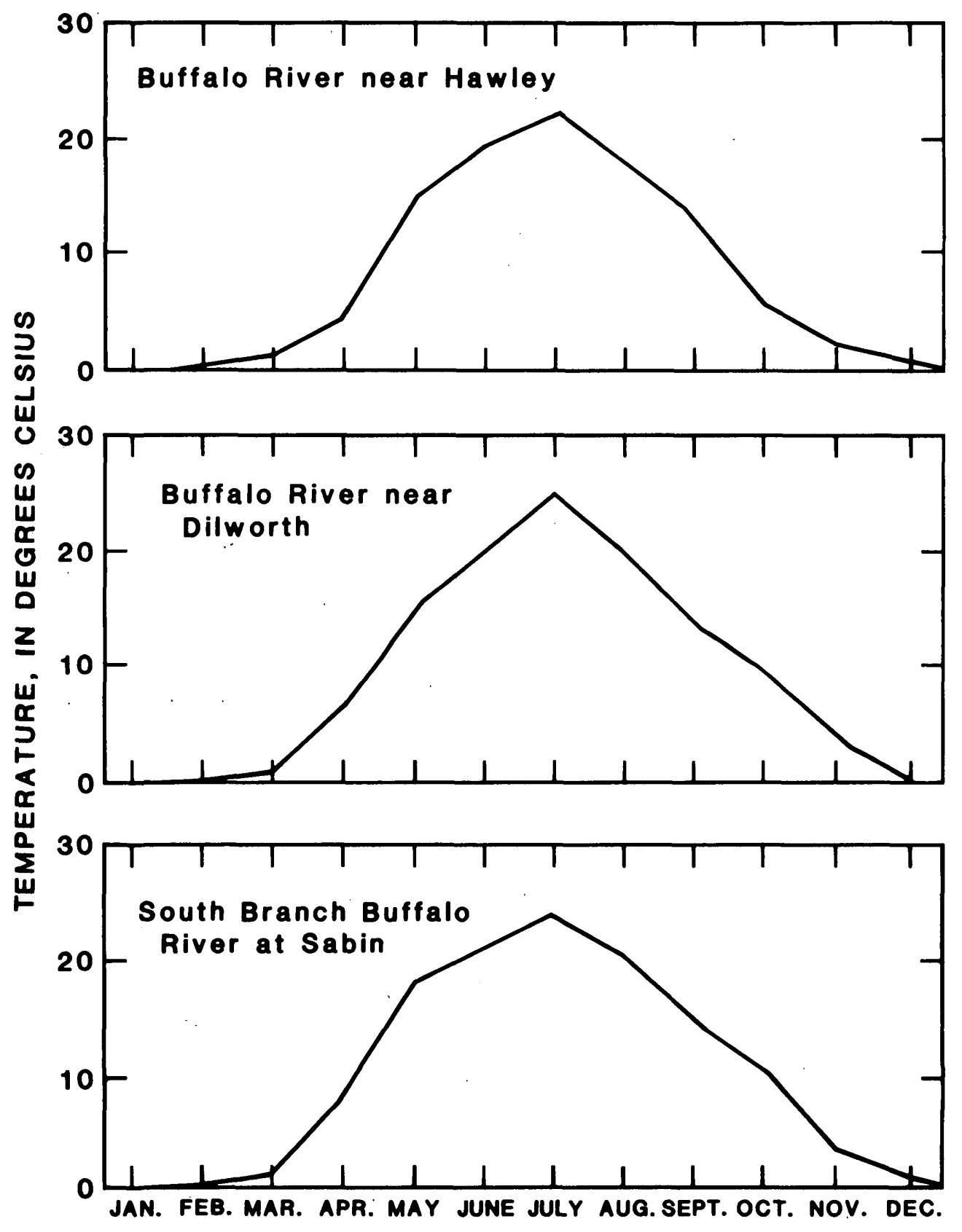

Flgure 27.--Mean monthly temperature of the South Branch Buffalo River and the Buffalo River near Hawley and near Dllworth 

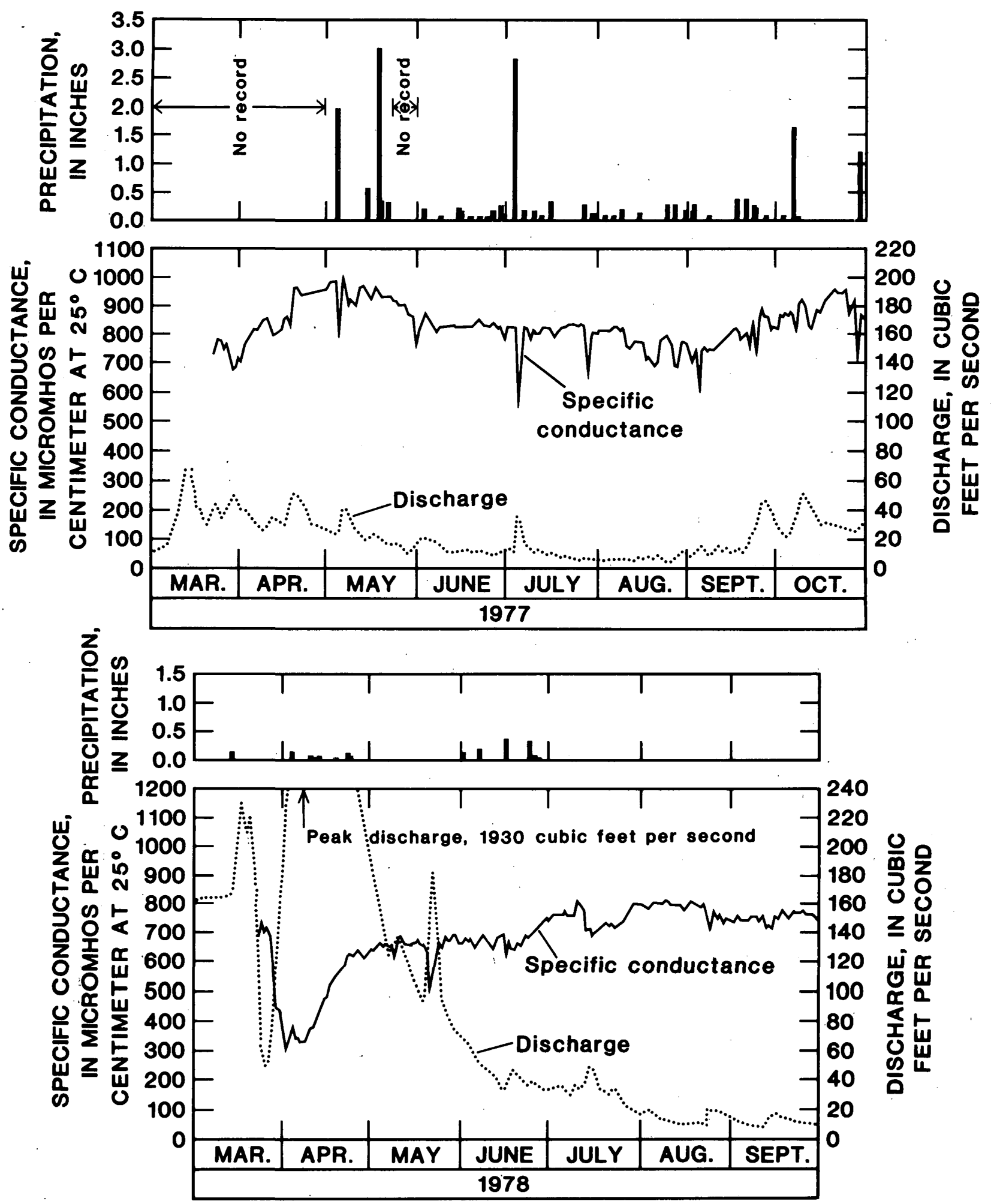

FIgure 28.--Relationshlp of specific conductance, streamflow, and precipitation 1977-1978, Buffalo River near Hawley 


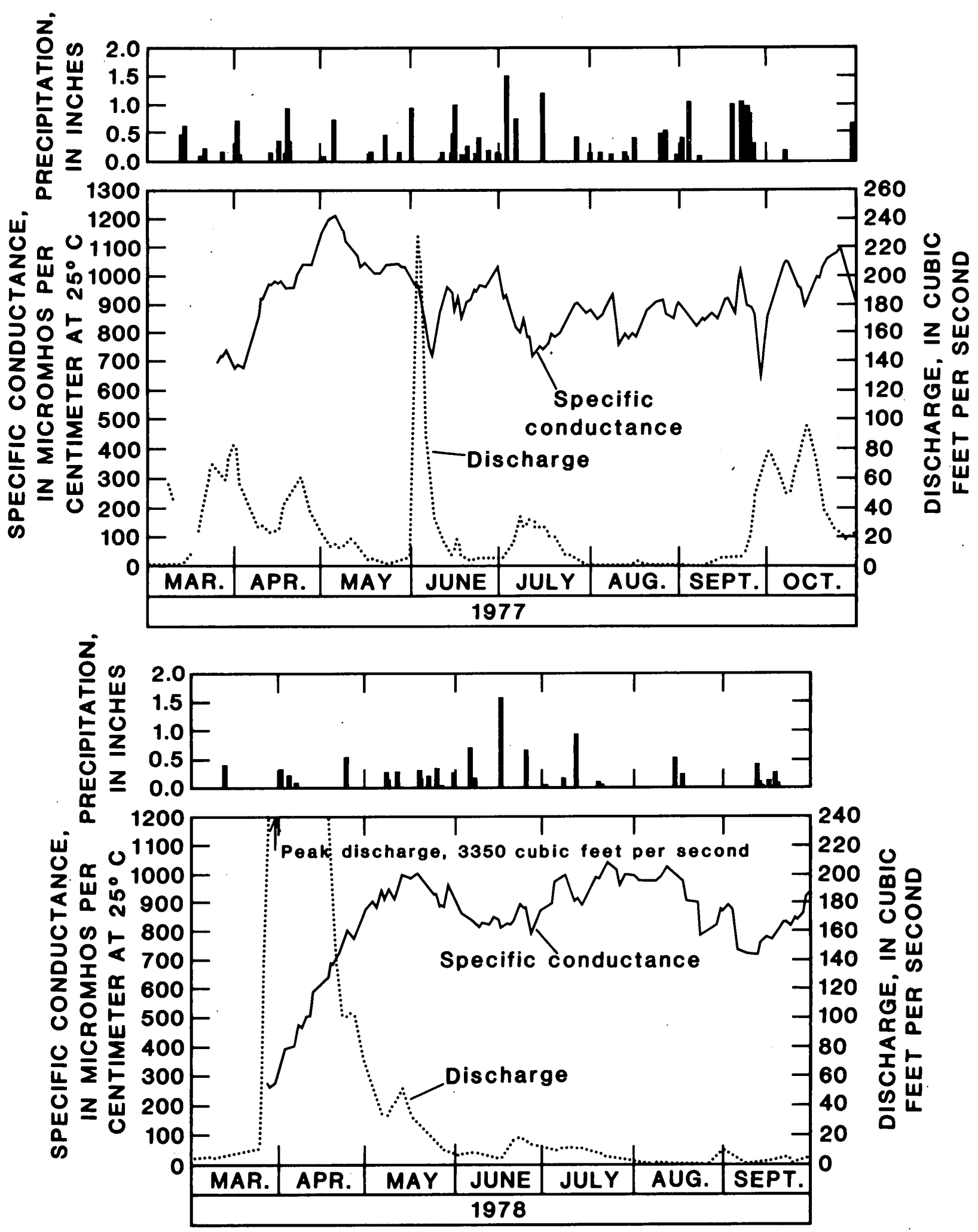

Figure 29.--Relationship of specific conductance, streamflow, and precipitation 1977-78, South Branch Buffalo River at Sabin 

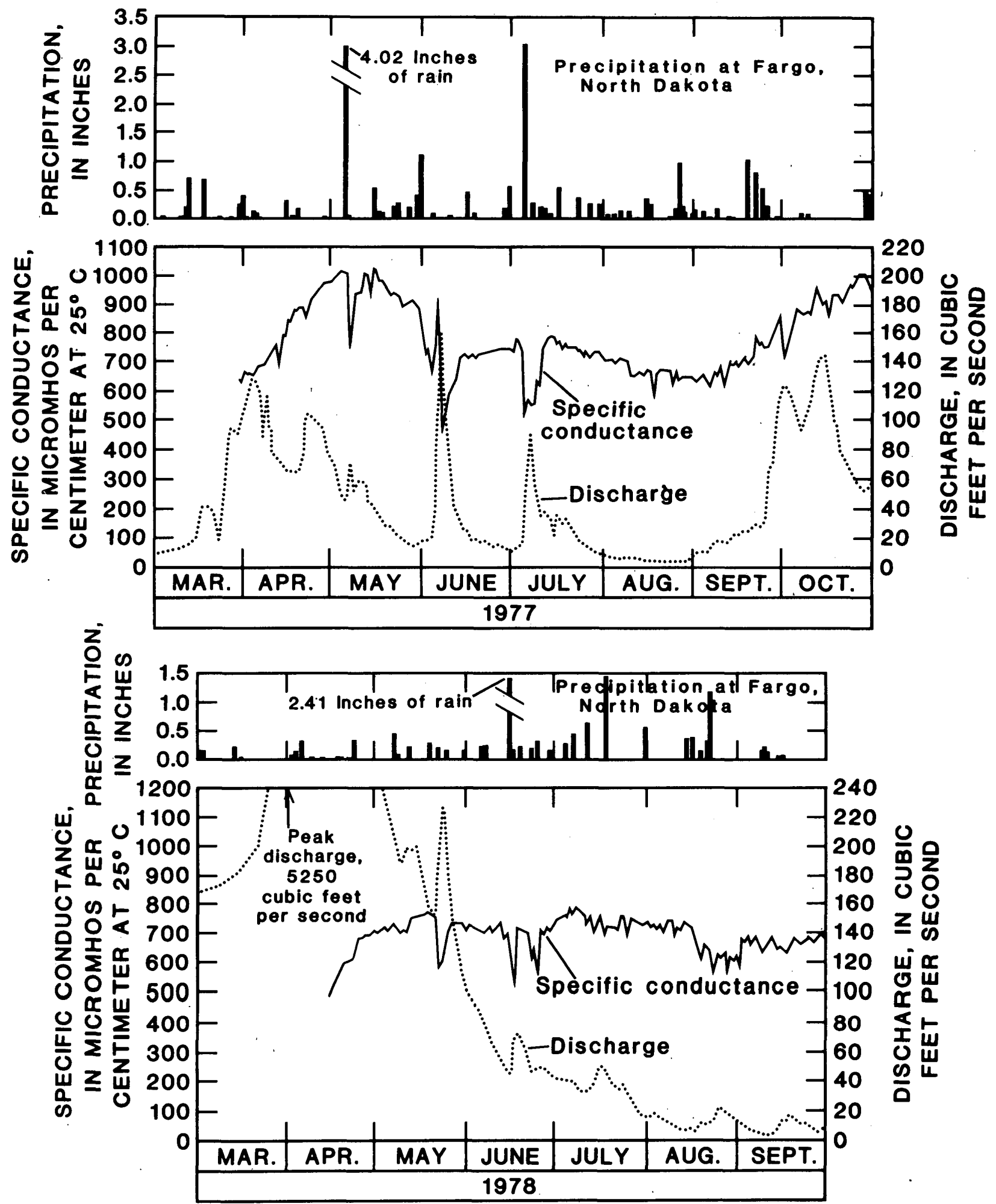

Figure 30.--Relationship of specific conductance, streamflow, and precipitation 1977-78, Buffalo River near DIlworth 
the field range from initial values to reflect higher values expected in the coarser deposits of the deep trough along the axis of the aquifer. These changes somewhat improved the simulation of head values, but unreasonably low recharge values had to be used to even approach the measured water leve1s.

Reexamination of the model results led to the conclusion that a considerable quantity of discharge must be taking place through the confining bed to either the adjacent stream or laterally to the west toward the Red River of the North. Data necessary to confirm this discharge, its direction, and its magnitude are not available at present. However, estimates were made to allow vertical leakage through the nodes along the eastern edge of the model, thus simulating discharge through the lake sediments to the adjacent stream. The model then indicated a better match between measured and calculated water levels. In addition, the model was sensitive to whatever estimates were used for vertical hydraulic conductivity, water level in the confining bed, and thickness of the confining bed. include,

More data are needed to construct a calibrated model. Data needs

1. Definition of the water table and variations in head through the confining bed

2. Better definition of thickness of confining bed, especially where a stream overlies the aquifer

3. Better definition of vertical hydraulic conductivity of the confining bed

4. Determination of the interconnection of the stream with the aquifer, including identification of streambed material

5. Better definition of potentiometric level in the aquifer to show component of flow in east-west direction, that is, the direction of flow between aquifer and stream

6. Continued monitoring of water levels in areas both affected and unaffected by pumpage so that long-term water-level changes $c a n$ be determined at selected observation wells and stream-stage measuring sites

7. Water use from aquifer and stream should be monitored closely so that pumpage can be related to water-level change

8. Precipitation records along the length of the aquifer to determine differences with respect to both time and place

9. Continued monitoring of flow and sediment at the stream-gaging stations 
10. Periodic low-flow seepage runs to define gaining and losing reaches of the stream in both summer and autumn

Acquisition of these data would improve calibration of the model and would permit simulation of water levels under both steady-state and transient conditions. The improved model could be used to evaluate development plans.

\section{Water Quality}

Water from the Buffalo aquifer is mostly a very hard calcium bicarbonate type that contains dissolved solids generally in the range of 300 to 1,900 $\mathrm{mg} / \mathrm{L}$.

Chemical suitability of water for irrigation depends on the type, concentration, and relative proportions of dissolved-mineral constituents. Salinity and sodium-adsorption-ratio are two factors that could be critical to plant growth and to changes in soil structure. Water from the Buffalo aquifer has a low sodium hazard and a medium-to-high salinity hazard (fig. 31) according to a classification developed by the U.S. Salinity Laboratory Staff (1954). The indicated salinity hazard should not be a problem because good drainage characteristics of the soils and ample precipitation provide sufficient flushing and leaching to prevent salt accumulation.

Boron in trace amounts is essential to the normal growth of all plants, but is exceedingly toxic at concentrations above recommended limits. Concentrations of boron in water samples, as shown in table 1 , are below critical concentrations for crops raised in western Minnesota.

Table 1 shows a comparison for mean, median, and range of various constituents or properties of water taken from 46 wells in the Buffalo aquifer in 1957 and 20 wells in 1978. Locations of the 66 sampling sites are shown in figure 32. Although the samples were not from the same wells, they were taken from the same aquifer about 20 years apart and suggest that changes may have taken place in the water quality. The table indicates higher mean, median, and maximum concentrations of iron, calcium, magnesium, sulfate, dissolved solids, hardness, specific conductance, temperature, and color for the 1978 samples than for the 1957 samples. Conversely, the table shows lower concentrations of silica, sodium, potassium, sodium-adsorption ratio, sodium percentage, and $\mathrm{pH}$ for the 1978 samples than for the 1957 samples .

The increased concentrations of some cations and anions may be indicative of changes in head, with respect to time, between the Buffalo aquifer and the buried drift and bedrock aquifers. Such changes in head, due to increased pumping from the aquifer for more than 30 years, may have induced greater upward leakage of poorer-quality water from deeper aquifers and locally altered the chemical quality of water in the Buffalo aquifer. An understanding of the relationship of chemical quality to the regional flow system helps explain some apparent increases in certain areas, as explained on page 62 . 


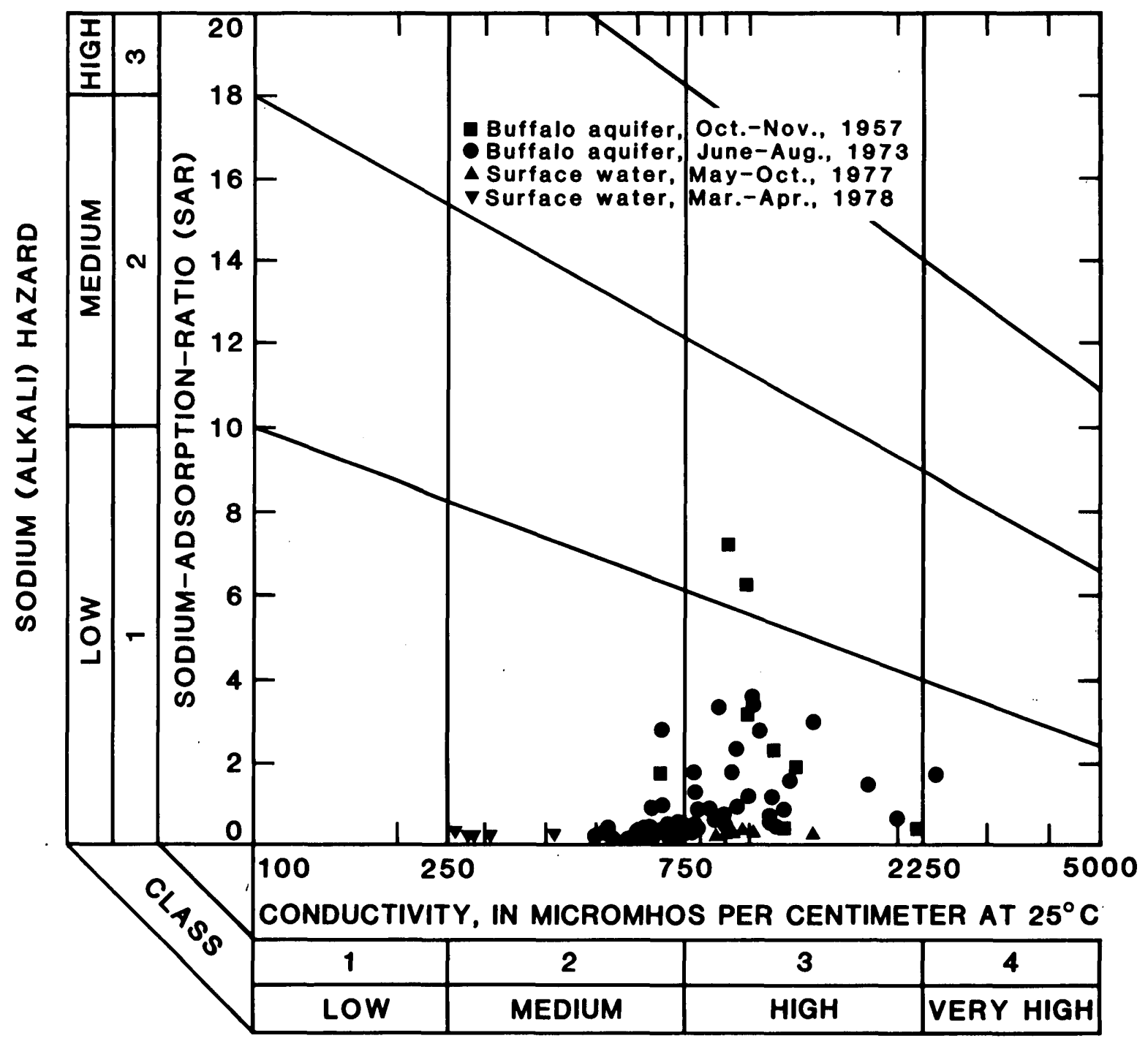

SALINITY HAZARD

Figure 3 1.--Sultabillty of water from the Buffalo aquifer and water from nearby streams for Irrigation in terms of sodium-adsorption-ratio and conductivity 
NORTHERN PORTION OF STUDY AREA

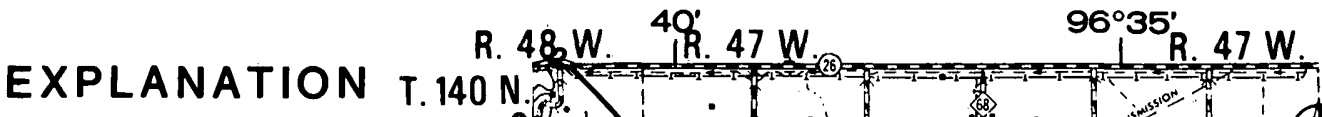

0

Ground-water sampling site, October-November, 1967

Ground-water sampling site, June-August, 1978

Buffalo-aquifer boundary

T. 139 N
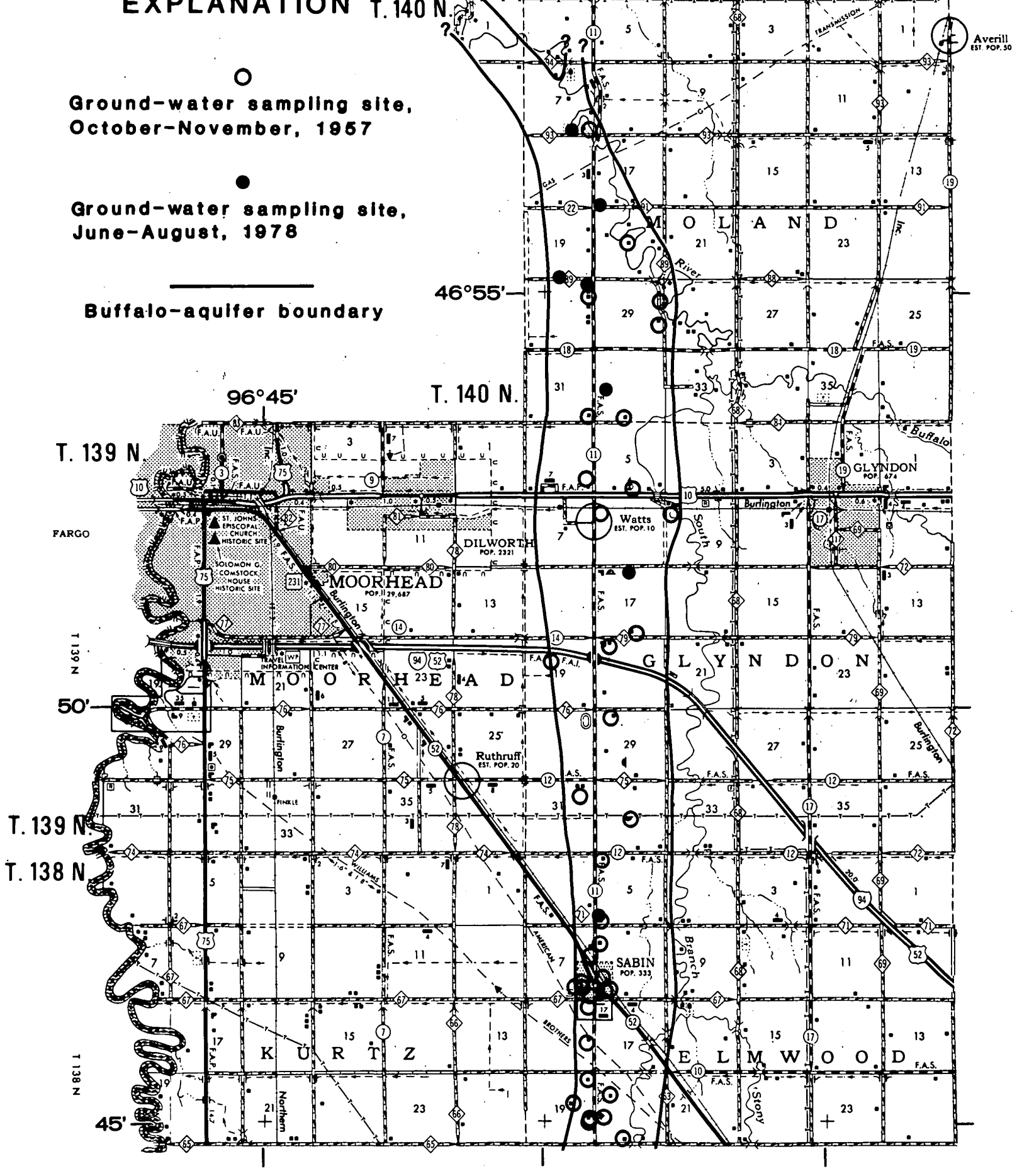

FIgure 32.--Ground-water-quallty 


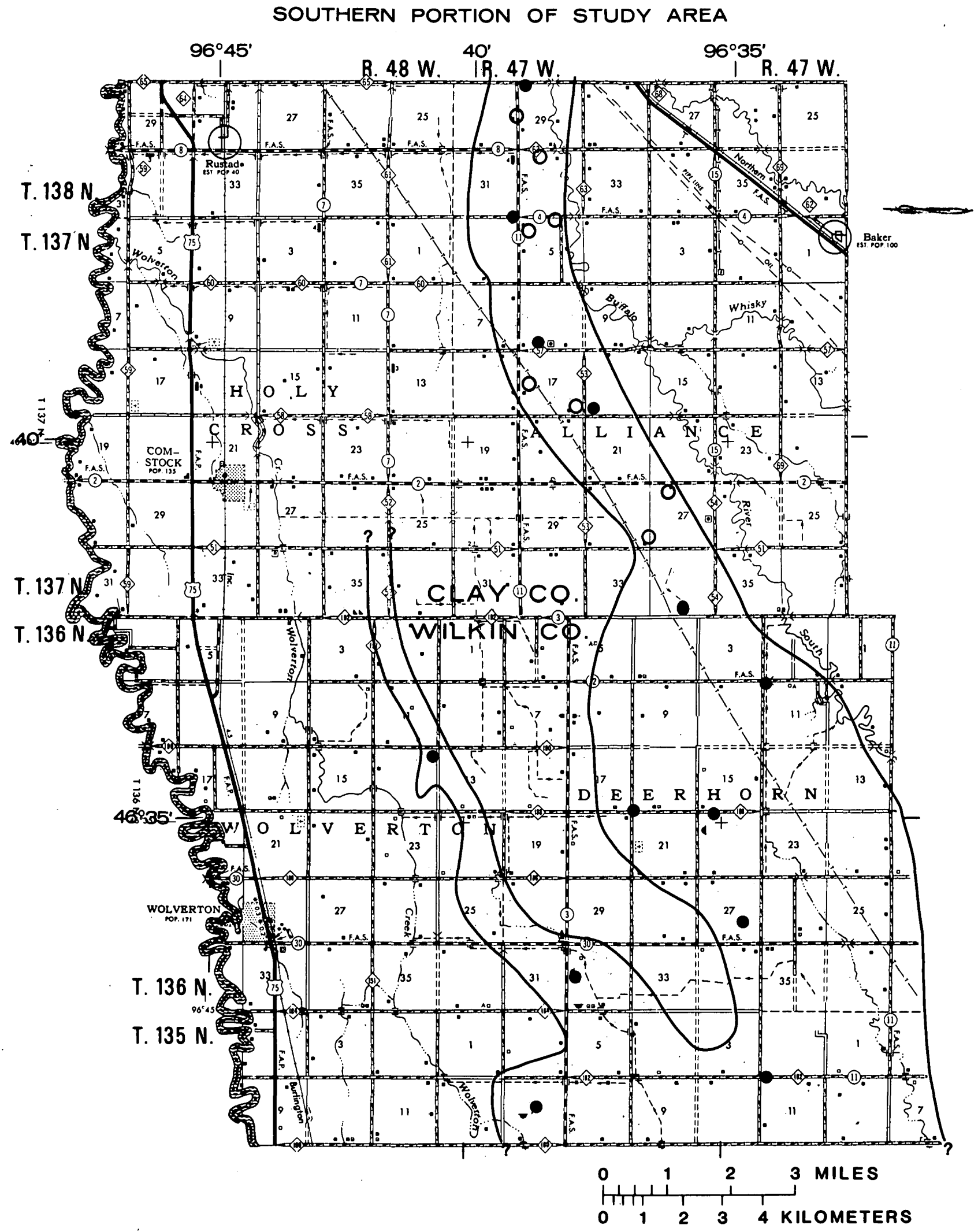

sampllng sltes In the Buffalo aqulfer 
Table 1.--Comparison of water quality in the Buffalo aquifer, 20 years apart

[Chemical constituents are given in milligrams per liter]

\begin{tabular}{|c|c|c|c|c|c|c|c|c|c|c|}
\hline \multirow[t]{2}{*}{ FACTORS } & \multicolumn{2}{|c|}{ MEAN } & \multicolumn{2}{|c|}{ MEDIAN } & \multicolumn{6}{|c|}{ RANGE } \\
\hline & $\begin{array}{c}\text { Date } \\
\text { sampled } \\
\text { Oct.-Nov. } \\
1957\end{array}$ & $\begin{array}{c}\text { Date } \\
\text { sampled } \\
\text { June-Aug. } \\
1978 \\
\end{array}$ & $\begin{array}{c}\text { Date } \\
\text { sampled } \\
\text { Oct.-Nov. } \\
1957 \\
\end{array}$ & $\begin{array}{c}\text { Date } \\
\text { sampled } \\
\text { June-Aug. } \\
1978 \\
\end{array}$ & $\begin{array}{r}\mathrm{Da} \\
\text { sam } \\
\text { Oct } \\
19 \\
\end{array}$ & $\begin{array}{l}\text { te } \\
\text { ap } 1 \\
-1 \\
57\end{array}$ & lov. & $\begin{array}{r}\mathrm{Da} \\
\text { Sam } \\
\text { June } \\
19 \\
\end{array}$ & $\begin{array}{l}\text { at } \\
\mathrm{mp} \\
\mathrm{e}- \\
97\end{array}$ & \\
\hline $\begin{array}{l}\text { Silica }\left(\mathrm{SiO}_{2}\right) \ldots \\
\text { Iron }(\mathrm{Fe})\end{array}$ & 29 & 26 & 29 & 25 & 18 & - & 33 & 21 & - & 29 \\
\hline$\underset{\text { Manganese }}{\operatorname{Totan})}$ & 1.0 & 11 & .73 & 7.4 & 0 & - & 4.6 & .11 & - & 45 \\
\hline $\begin{array}{r}\text { Total. } \ldots \ldots \ldots \\
\text { Calcium } \\
(\mathrm{C} a) \ldots \ldots\end{array}$ & $\begin{array}{r}.14 \\
88\end{array}$ & $\begin{array}{l}1.1 \\
188\end{array}$ & $\begin{array}{r}.12 \\
84\end{array}$ & $\begin{array}{l}.28 \\
110\end{array}$ & $\begin{array}{r}.02 \\
32\end{array}$ & - & $\begin{array}{l}.35 \\
181\end{array}$ & $\begin{array}{r}.05 \\
70\end{array}$ & $\begin{array}{l}- \\
-\end{array}$ & $\begin{array}{l}6.8 \\
260\end{array}$ \\
\hline Magnesium $(\mathrm{Mg}) \ldots$ & 34 & 65 & 33 & 40 & 13 & - & 83 & 22 & - & 230 \\
\hline Sodium (Na)..... & 38 & 33 & 21 & 10 & 2.9 & - & 159 & 3.2 & - & 140 \\
\hline Potassium $(K) \ldots$ & 6.2 & 5 & 5.7 & 4.8 & 3.0 & - & 15 & 2.4 & - & 11 \\
\hline $\begin{array}{l}\text { Lithium (Li)..... } \\
\text { Bicarbonate }\end{array}$ & .5 & -- & .5 & -- & 0 & - & 1.5 & & & -- \\
\hline$\underset{\text { Carbonate }}{\left(\mathrm{HCO}_{3}\right)} \ldots \ldots \cdots$ & 362 & 348 & 358 & 360 & 279 & - & 478 & 200 & - & 490 \\
\hline$\left(\mathrm{CO}_{3}\right) \ldots \ldots \ldots$ & .99 & 0 & 0 & 0 & 0 & - & 19 & & & 0 \\
\hline $\begin{array}{l}\text { Sulf fate }\left(\mathrm{SO}_{4}\right) \ldots \ldots \\
\text { Chloride }(\mathrm{Cl}) \ldots\end{array}$ & $\begin{array}{l}145 \\
7.2\end{array}$ & $\begin{array}{l}319 \\
7.0\end{array}$ & $\begin{array}{l}108 \\
3.5\end{array}$ & $\begin{array}{l}190 \\
4.4\end{array}$ & $\begin{array}{r}21 \\
0\end{array}$ & - & $\begin{array}{r}545 \\
39\end{array}$ & $\begin{array}{r}37 \\
1.1\end{array}$ & - & $\begin{array}{r}1100 \\
54\end{array}$ \\
\hline Fluoride (F).... & .3 & .2 & .2 & .2 & 0 & - & .9 & 1 & - & .3 \\
\hline $\begin{array}{l}\text { Nitrate }\left(\mathrm{NO}_{3}\right) \ldots \\
\mathrm{NO}_{2}+\mathrm{NO}_{3}\end{array}$ & 1.0 & --- & .8 & -- & 0 & - & 5.5 & & & $-\cdots$ \\
\hline $\begin{array}{l}\text { Total as } N \ldots \\
\text { Nitrogen }\end{array}$ & --- & .53 & --- & 0 & & & --- & 0 & - & 10 \\
\hline $\begin{array}{l}\text { Total as N.... } \\
\text { Nitrogen }\end{array}$ & --- & .96 & $\cdots$ & .50 & & & --- & .14 & - & 10 \\
\hline TotKJD as N... & -- & .43 & -- & .39 & & & --- & .14 & - & .80 \\
\hline $\begin{array}{l}\text { Phosphate }\left(\mathrm{PO}_{4}\right) \ldots \\
\text { Phosphorus }\end{array}$ & .4 & --- & .2 & -- & 0 & - & 3.3 & & & -- \\
\hline$($ as $P) \ldots \ldots$ & --- & .28 & $-\infty$ & .04 & & & --- & & - & 3.6 \\
\hline $\begin{array}{l}\text { Boron (B) ...... } \\
\text { Dissolved } \\
\text { solids } \\
\text { (residue on } \\
\text { evaporation }\end{array}$ & .13 & .13 & .10 & .09 & .02 & - & .33 & .01 & - & .43 \\
\hline $\begin{array}{l}\left.\text { at } 180^{\circ} \mathrm{C}\right) \ldots \ldots \\
\text { Dissolved } \\
\text { solids } \\
\text { (calculated }\end{array}$ & 541 & 787 & 490 & 604 & 316 & & 1190 & 305 & - & 1990 \\
\hline sum) $\ldots \ldots \ldots$ & 512 & 750 & 488 & 584 & 305 & & 1100 & 340 & & 1820 \\
\hline Hardness: & & & & & & & & & & \\
\hline Total........ & 370 & 564 & 354 & 450 & 133 & - & 793 & 270 & - & 1400 \\
\hline $\begin{array}{l}\text { Noncarbonate... } \\
\text { Sodium- } \\
\text { absorption }\end{array}$ & 80 & 273 & 59 & 140 & 0 & & 442 & 36 & & 1000 \\
\hline $\begin{array}{l}\text { ratio } \ldots \ldots \ldots \ldots \\
\text { Sodium }\end{array}$ & - & .7 & .5 & .5 & .1 & 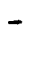 & 3 & .1 & - & 1 \\
\hline $\begin{array}{l}\text { percentage..... } \\
\text { Specific con- }\end{array}$ & 17 & 11 & 11 & 10 & 2 & & 58 & 3 & - & 20 \\
\hline $\begin{array}{l}\text { ductivity..... } \\
\text { Hydrogen ion } \\
\text { concentration } \\
\text { expressed as }\end{array}$ & 789 & 986 & 789 & 828 & 505 & & 1500 & 478 & & 2250 \\
\hline pH............ & 7.8 & 7.5 & 7.8 & 7.5 & 7.3 & & 8.5 & 7.2 & - & 7.9 \\
\hline Temperature $\left({ }^{\circ} \mathrm{C}\right)$. & 8.5 & 10.0 & 8.0 & 9.0 & 7.0 & & 13.5 & 8.5 & & 10.5 \\
\hline 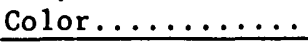 & -- & -- & 6 & 5 & 1 & & 10 & 5 & - & 30 \\
\hline
\end{tabular}


According to Maclay and Winter (1967) and Maclay and others (1972), calcium bicarbonate type water occurs in the shallow recharge areas in the eastern part of the Buffalo River watershed and progressively changes to sulfate or sodium bicarbonate type water in the direction of water flow. Calcium bicarbonate type water extends to greater depths in the lake plain in those areas where more permeable deposits, such as the Buffalo aquifer, form the ground-water reservoir.

Sulfate type water locally underlies bicarbonate type water. In general, sulfate water occurs at greater distance from the recharge areas than the calcium bicarbonate water. Sulfate concentrations tend to increase from east to west, indicating a general westward movement of water; however, sulfate concentrations are locally very low, probably as a result of reduction by anaerobic bacteria.

Chloride type water in the Cretaceous rocks and at depth in the drift in the western part of the watershed is highly saline in relative composition of the major ions. Although the Cretaceous rocks contain highly soluble minerals that contribute to the high salinity, most of the salinity probably has accumulated during the slow eastward migration of water toward a regional discharge area in northwestern Minnesota. Upward discharge of the chloride type water in the western part of the Buffalo River watershed causes mixing of chloride water with bicarbonate or sulfate water in the drift to form a calcium magnesium chloride type.

Hard water moving from the upper drift into the lower drift and (or) Cretaceous rocks is softened by ion exchange, which results in a sodium bicarbonate type water. Pumping from the Buffalo aquifer may have induced the more saline waters underlying the aquifer to move upward through the till and mix with the calcium bicarbonate water in the Buffalo aquifer.

\section{SURFACE-WATER EVALUATION}

\section{Streamflow Characteristics}

Streams of the Buffalo River watershed are (1) small tributaries of the Red River of the North from Wahpeton, No. Dak., to the mouth of the Buffalo River, (2) Buffalo River, (3) South Branch Buffalo River, and (4) smaller tributaries of the Buffalo River.

Streamflow records date back to the turn of the century for the Red River at Fargo, N. Dak. In the 1930's and 1940's, stations were established on the Buffalo River and its largest tributary, the South Branch Buffalo River. At present (1979), flow data are being collected at three continuous-record sites on the Red River, two sites on the Buffalo River, 
and one site on the South Branch Buffalo River. Periodic discharge measurements have been made at four low-flow and three crest-stage partialrecord sites. The location and type of station are shown in figure 33; selected flow characteristics are shown in table 2. In addition, many miscellaneous measurements have been obtained at other sites.

\section{Average discharge}

The average discharge is the theoretical maximum quantity of water that can be developed from a stream for water supply. Analysis of flow records indicates that the average discharge per square mile of streams in the Buffalo River watershed is not uniform, but is affected by characteristcs of the areas drained by the streams.

Flow of the South Branch Buffalo River at Sabin is representative of streams draining the lake plain and flow of the Buffalo River near Hawley is representative of streams draining the moraine area. Flow of the lower reach of the Buffalo River near Dilworth represents the combined flow from the lake plain and moraine area.

The three continuous-record gaging stations in the Buffalo River system have a common 33-year period of record through 1978. The average flow for the South Branch Buffalo River at Sabin is $0.108\left(\mathrm{ft}^{3} / \mathrm{s}\right) / \mathrm{mi}^{2}$, the Buffalo River near Hawley is $0.229\left(\mathrm{ft}^{3} / \mathrm{s}\right) / \mathrm{mi}^{2}$, and the lower reach of the Buffalo River near Dilworth is $0.148\left(\mathrm{ft}^{3} / \mathrm{s}\right) / \mathrm{mi}^{2}$. The average flow for 46 years of record at the gage near Dilworth, which includes the drought of the $1930 \mathrm{~s}$, is $0.125\left(\mathrm{ft}^{3} / \mathrm{s}\right) / \mathrm{mi}^{2}$. Comparatively, the long term (1901-78) average discharge of the Red River of the North at Fargo is $0.080\left(\mathrm{ft}^{3} / \mathrm{s}\right) / \mathrm{mi}^{2}$. The Red River average flow is less because it includes tributaries that lie west of its main stem in North Dakota where precipitation is lower.

The mean monthly discharge for the three gages on the Buffalo River system during 1946-78, is shown in figure 34. The bar graph shows the influence of the main stem and the South Branch on discharge of the lower reach of the Buffalo River. During spring and early summer, the South Branch is often the large contributor of surface runoff. But during late summer, fall, and winter, when streamflow is mostly from ground-water discharge, the greatest contribution comes from the main stem Buffalo River, as shown by the records of the gage near Hawley.

\section{Variability}

A noticeable variation in daily discharge is depicted by the duration curve, which indicates the percentage of time that a given flow has been exceeded during data collection. Duration curves were prepared for the three continuous-record gaging stations. An additional duration curve for 1946-78 for the gaging station near Dilworth was prepared so that all three stations could be compared on a common time basis (fig. 35). 


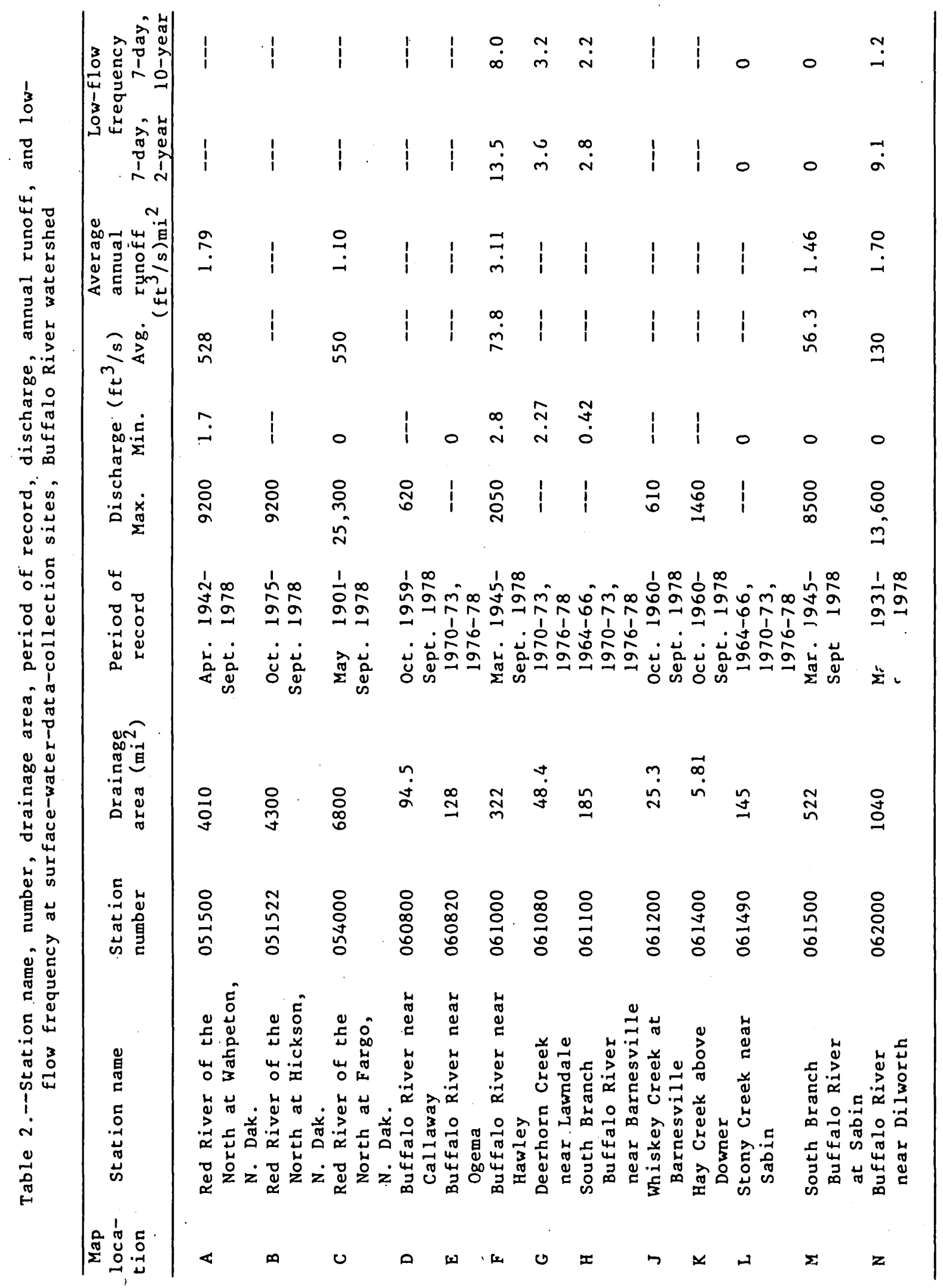




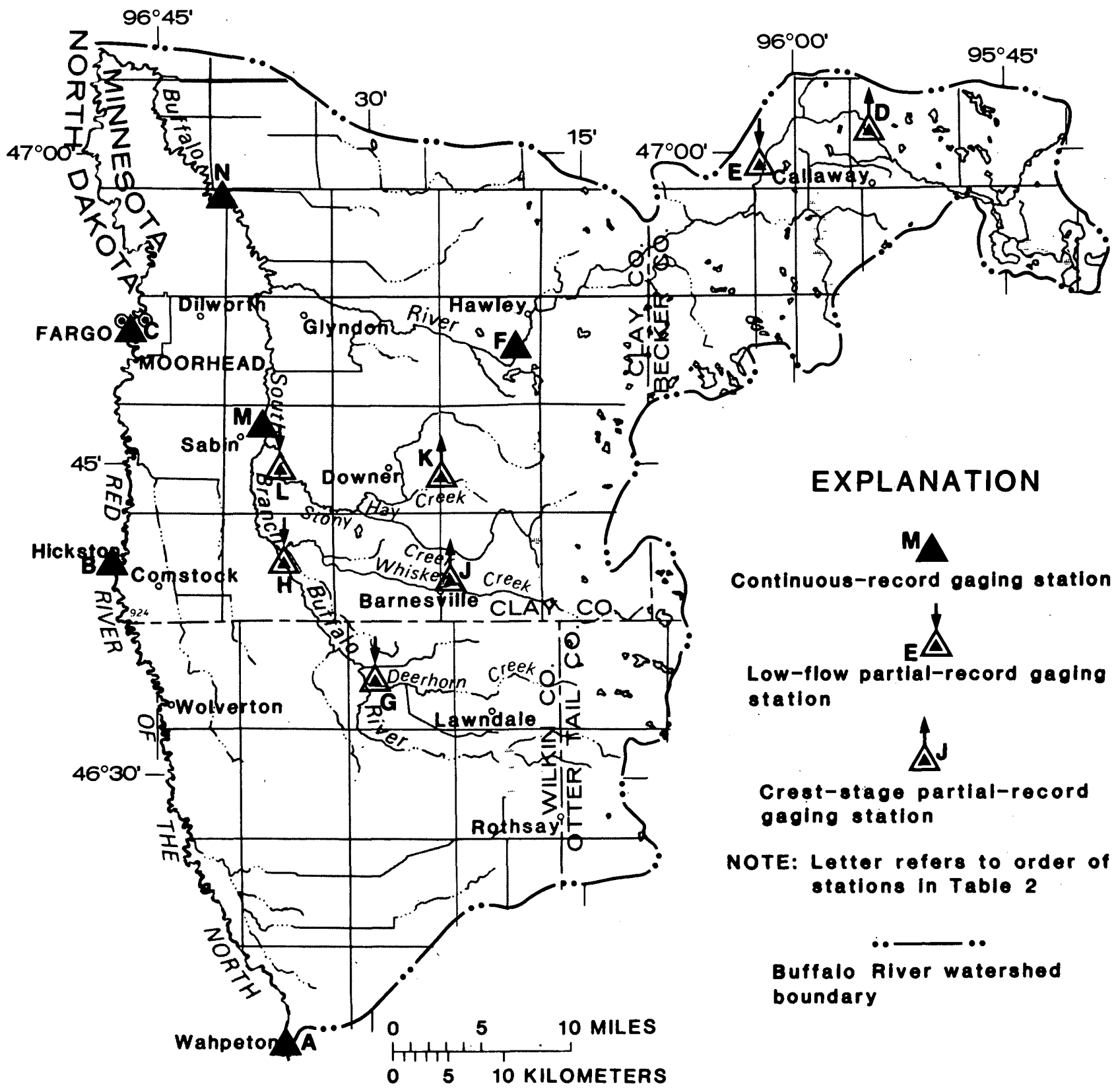

Figure 33.--Location and type of surface-waterdata-collectlon sltes in the Buffalo River watershed 


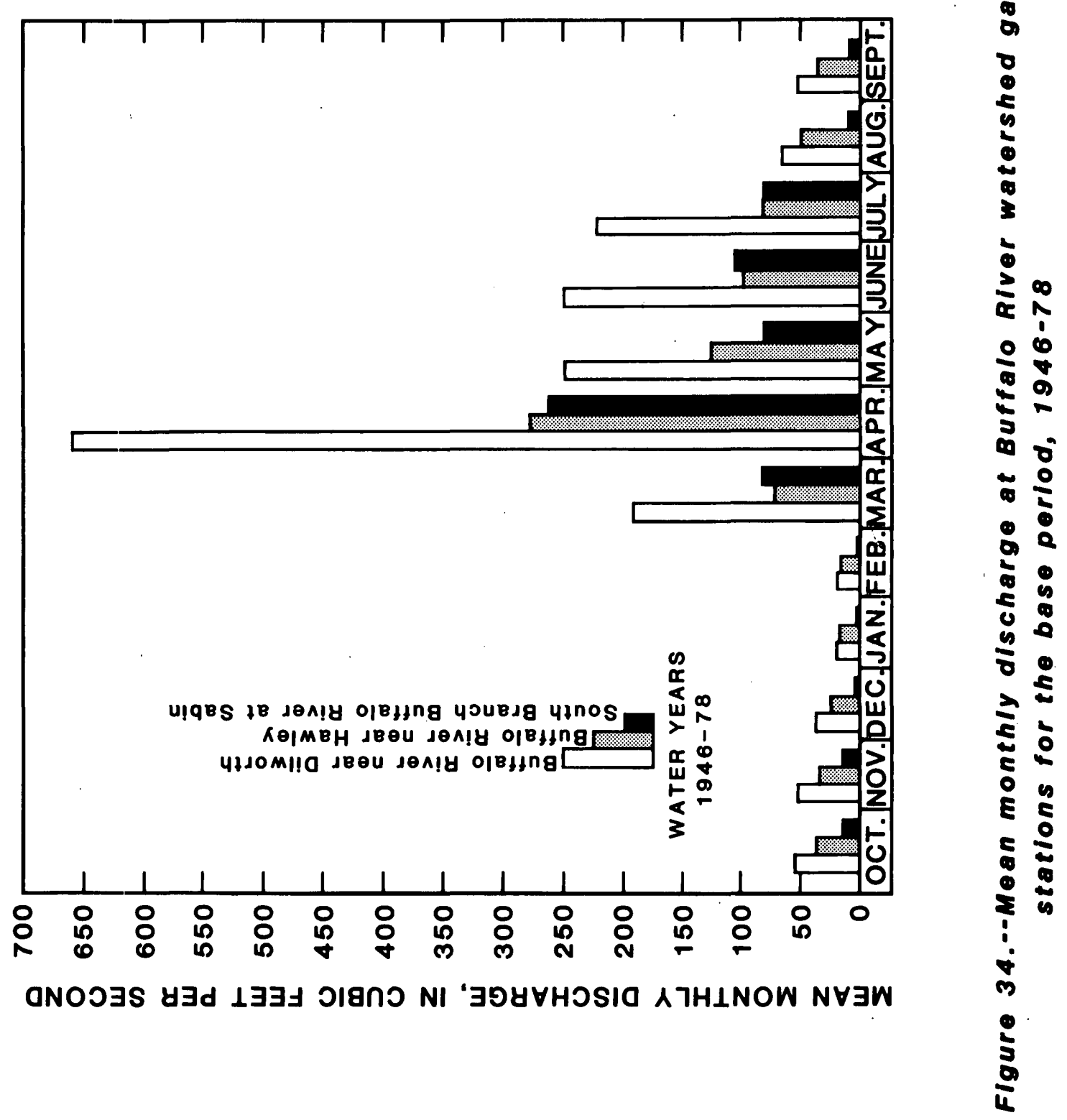




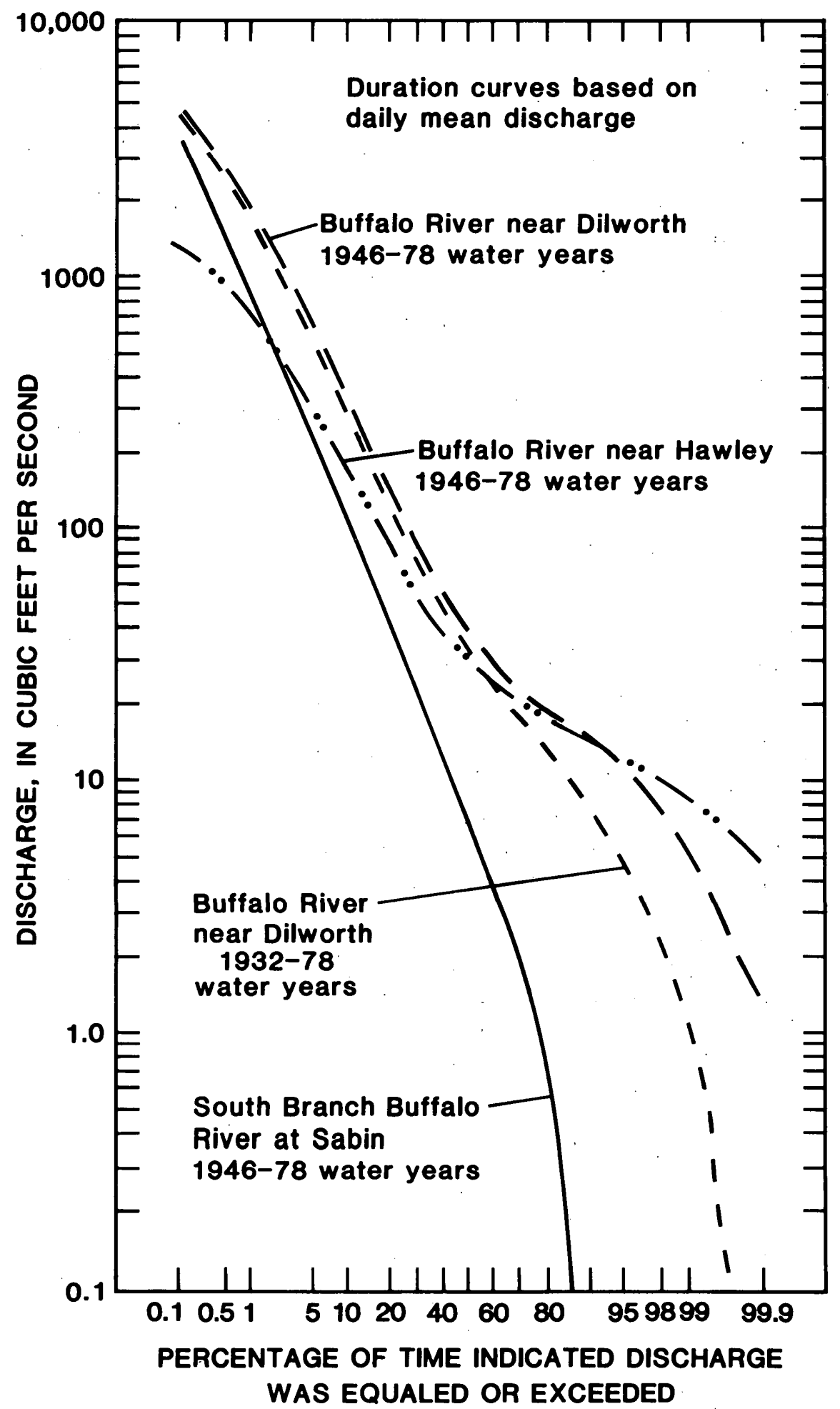

Figure 35.--Duration curves for gaged streams in the Buffalo River watershed 
Duration curves during 1946-78 vary considerably. The generally steep slope of the curve for the South Branch Buffalo River at Sabin denotes a highly variable stream whose flow is mostly from direct runoff. The slope of the lower end of the duration curve shows the characteristics of the perennial storage in the drainage basin. The somewhat flatter slope at the lower end of the curve for the gaging station near Hawley indicates a large quantity of storage or ground-water discharge. On the other hand, the steep slope of the lower end of the curve for the gage at Sabin indicates a lesser quantity of storage, although the sharp downward slope is also a result of ice in the upper tributaries of the South Branch Buffalo River.

The monthly duration hydrograph for the Buffalo River near Dilworth in figure 36 shows the variation of mean monthly discharge for each month and the seasonal variation of mean monthly discharge during 1932-78. The mean monthly discharge of the Buffalo River below the mouth of the South Branch Buffalo River is most uniform during late summer and midwinter.

\section{Low-flow frequency}

A disadvantage of the duration curve is that it does not account for the length of low-flow periods. This disadvantage is surmounted by a frequency analysis of the daily-mean flow for consecutive periods of various lengths. Low-flow frequency curves prepared for the three continuousrecord gaging stations are shown in figure 37 . Because low flow is largely from ground-water sources, frequency curves for other sites would differ from those shown because of variations in surficial geology. Figure 37 shows persistent low flow by the flat curves for the Buffalo River near Hawley. These flows are sustained by ground-water discharge, discharge from lakes, and many springs along the western part of the moraine area. The steep curves for the Buffalo River near Dilworth reflect the days of no flow that occurred in 1936 and the effect of low flow throughout the drought of: the 1930's. The steep curves for the South Branch Buffalo River at Sabin reflect long periods of no flow caused by ice in the upper tributaries.

\section{High-flow frequency}

Flooding is common in the Red River valley and along the Buffalo River. Most of the high flows on the Buffalo River and South Branch Buffalo River are from snowmelt, augmented by spring rains. Damages from high water are related to the height, velocity, duration, frequency, and season of flooding. These factors are considered in the design of reservoirs for flood control, storage, and augmentation of streamflow.

High-flow frequency curves for the three Buffalo River gaging stations are presented in Maclay and others (1969). The high-flow frequency curves for the three Buffalo River stations shown in figure 38 have been updated through 1978. High-flow frequency curves are useful in solving problems of reservoir design and operation. 


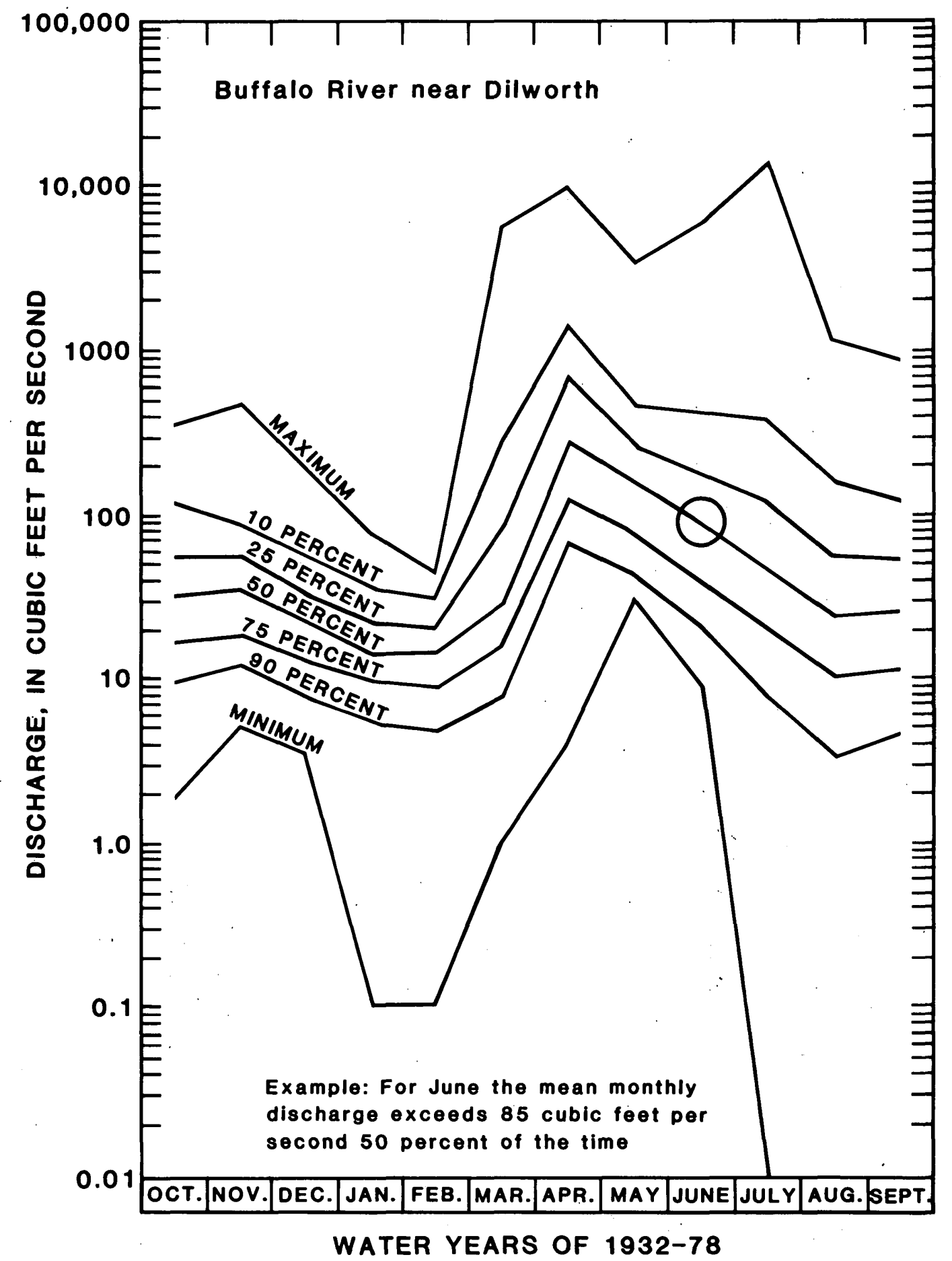

FIgure 36.--Duration hydrograph of mean monthly discharge for the Buffalo River near Dilworth 


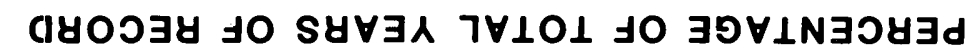

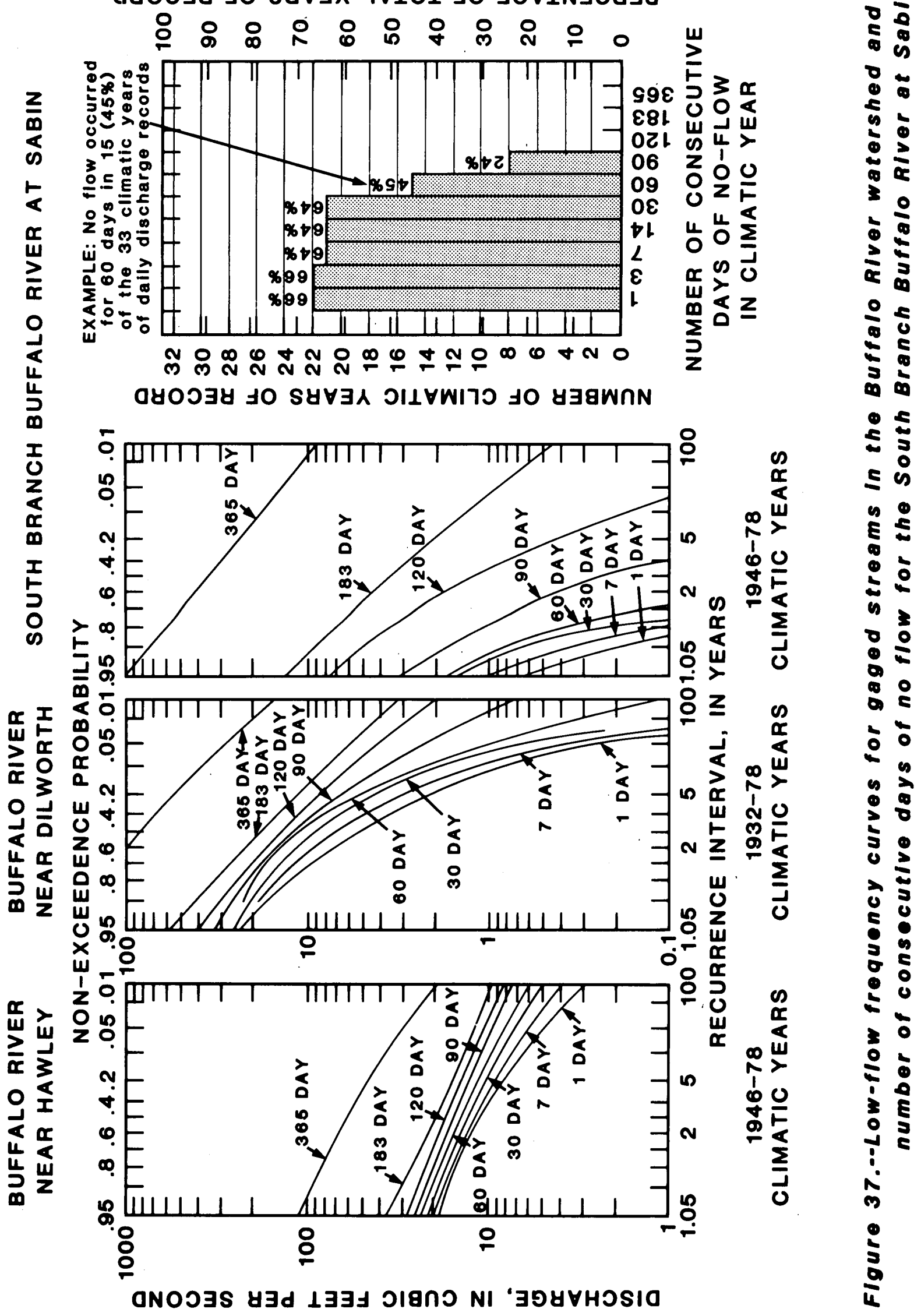




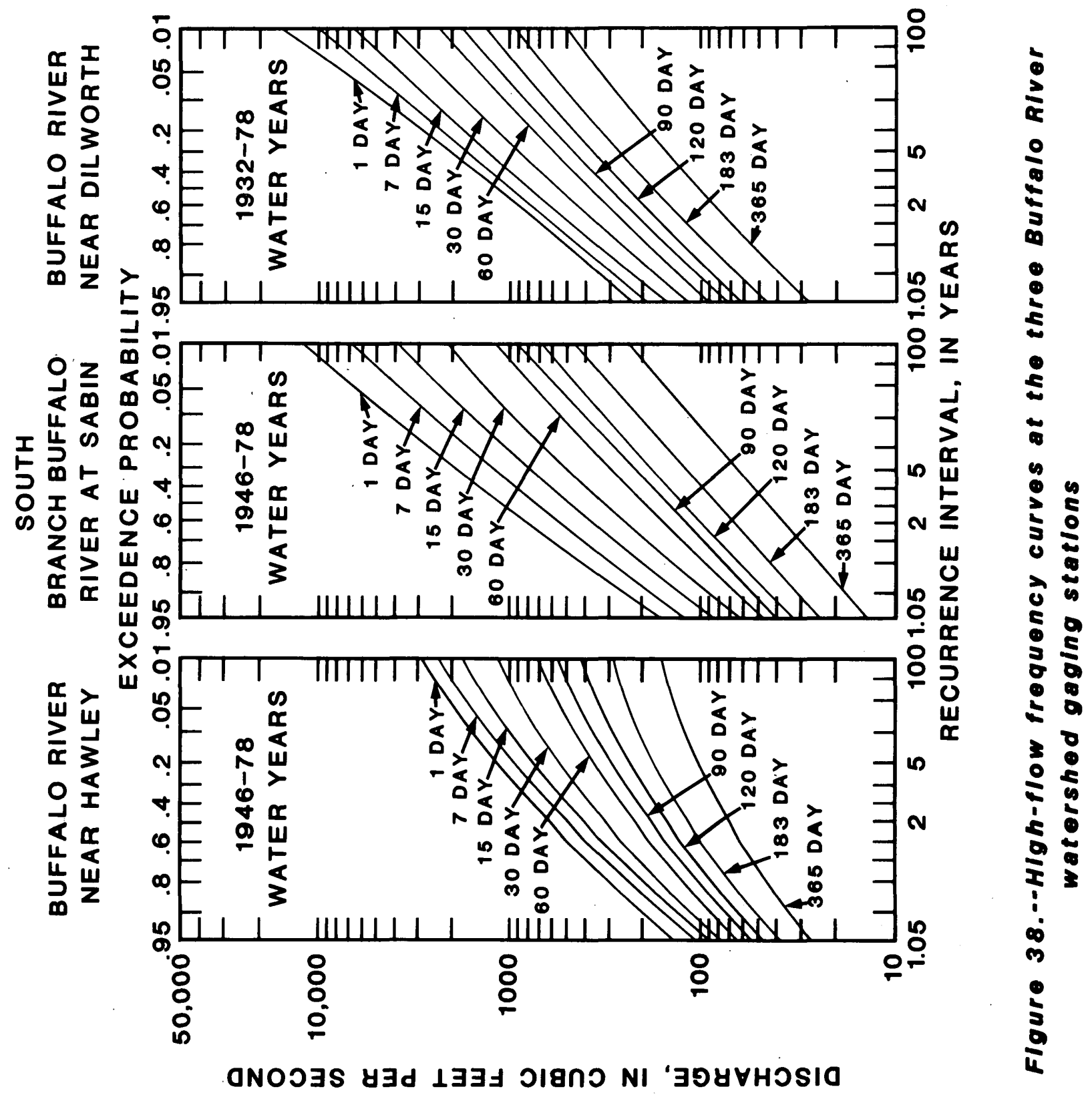




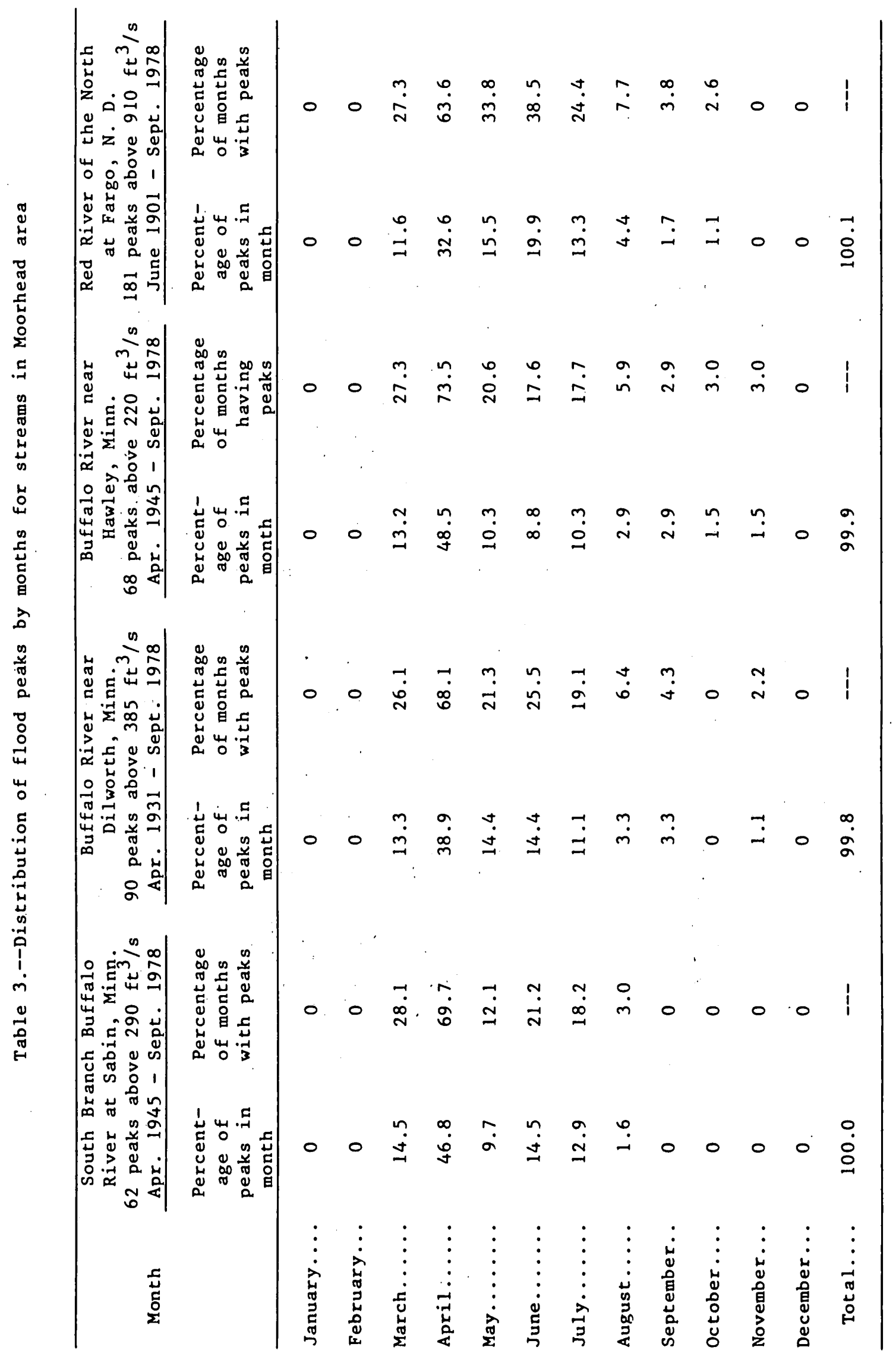


The distribution of peak flows by months was determined for streams to evaluate the seasonal pattern of floods. Peak flows used in the analysis are those exceeding the base established for each station. The base is defined as the rate of discharge that will be exceeded on an average of three times per year. Tabulation by month of the distribution of peaks above the base is given in table 3. Although streams flood throughout the year except the winter months of December, January, and February, approximately 90 percent of the floods are during March through July, with the greatest number in April.

\section{Fluvial Sediment}

All streams carry sediment that is transported either as bedload or as suspended load. For a particular stream, the discharge of suspended sediment from different parts of the watershed is primarily dependent on the amount of runoff. The sediment discharge is also dependent on the erodibility of the rocks and soils, slopes of the land and channel, and intensity and amount of precipitation. The effects of such factors as temperature, vegetative cover, and land use may be nearly uniform throughout the watershed.

Knowledge of the sediment-carrying capacity of streams is important in the design and operation of reservoirs and in the use of surface water for artificial recharge of ground-water reservoirs. A discussion of sediment discharge at the Buffalo River stations is presented because the use of reservoirs and artificial recharge of the Buffalo aquifer were considèred (Barr Engineering, Inc., 1975) as water-supply alternatives for Moorhèad.

Sediment data were collected at the sites shown in figure 39 . Suspended-sediment samples have been collected periodically at the gaging station near Dilworth since 1971 (table 4). Additional samples were collected periodically at the gaging stations near Hawley and at Sabin.

Table 4.--Sediment-sampling sites in the Buffalo River watershed and length of record

\begin{tabular}{|c|c|c|}
\hline Site & Type of record & Period of record \\
\hline $\begin{array}{r}\text { Buffalo River } \\
\text { near Hawley }\end{array}$ & $\begin{array}{l}\text { Generally collected } \\
\text { daily during open- } \\
\text { water period (usually } \\
\text { March through November) }\end{array}$ & $1977-78$ \\
\hline $\begin{array}{l}\text { South Branch } \\
\text { Buffalo River } \\
\text { at Sabin }\end{array}$ & do & $1977-78$ \\
\hline $\begin{array}{l}\text { Buffalo River } \\
\text { near Dilworth }\end{array}$ & $\begin{array}{l}\text { Periodically collected } \\
\text { when river stage is at } \\
\text { or above } 4.0 \mathrm{ft} \text { during } \\
\text { open-water periods }\end{array}$ & $1971,1973-78$ \\
\hline
\end{tabular}




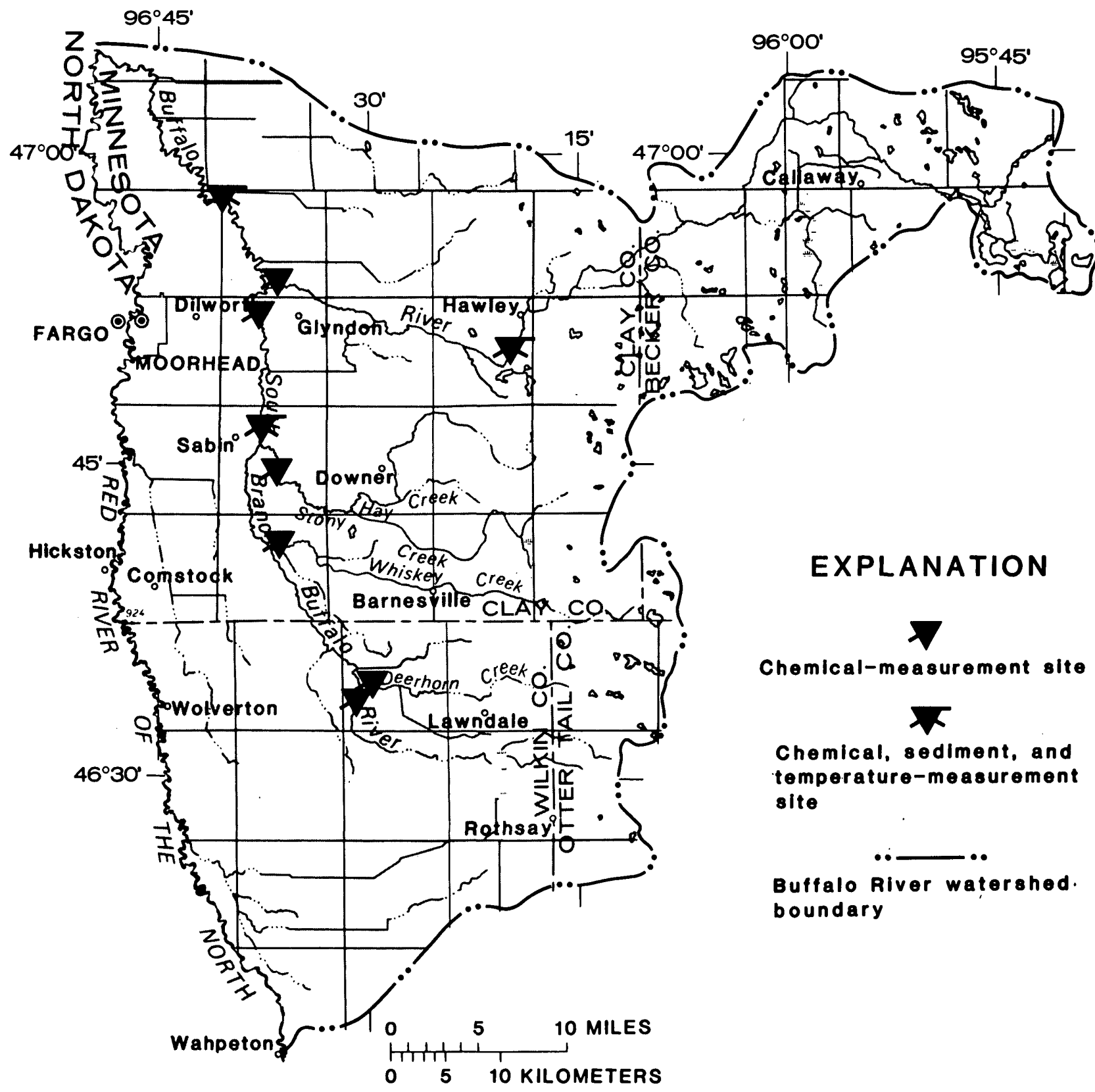

FIgure 39.--Surface-water-quallty samplling sites In the Buffalo Rlver watershed 
Suspended-sediment discharge varies, but if a long period of record is available, the estimated average suspended-sediment discharge can be used in planning water-resources developments. When the average suspendedsediment discharge is computed per unit of drainage area, the values obtained can be used as indicators of the sediment yield from different areas.

Only relatively short periods of record of sediment discharge are available for streams in the Buffalo River watershed. In order to determine long-term averages, the sediment discharges were correlated with water discharges for which long-term averages and variabilities are known (duration curves, fig. 35). The correlations between sediment discharge and water discharge are shown by the sediment-transport curves in figure 26 .

The estimated average daily and average annual sediment discharges and the annual sediment yield for the three gaging stations in the Buffalo River watershed are given in table 5 .

Table 5.--Estimated average suspended-sediment discharge at Buffalo River watershed stations

\begin{tabular}{lcccc}
\hline Station name & $\begin{array}{c}\text { Period of } \\
\text { streamflow } \\
\text { record }\end{array}$ & $\begin{array}{c}\text { Average suspended-sediment discharge } \\
\text { per day }\end{array}$ & $\begin{array}{c}\text { Tons } \\
\text { per year }\end{array}$ & $\begin{array}{c}\text { Tons per square } \\
\text { mile per year }\end{array}$ \\
\hline $\begin{array}{c}\text { Buffalo River near } \\
\text { Hawley }\end{array}$ & $1946-78$ & 12.4 & 4,536 & 14.2 \\
$\begin{array}{c}\text { South Branch Buffalo } \\
\text { River at Sabin }\end{array}$ & $1946-78$ & 5.6 & 2,053 & 3.9 \\
$\begin{array}{c}\text { Buffalo River near } \\
\text { Dilworth }\end{array}$ & $1946-78$ & 27.6 & 10,077 & 9.7 \\
$\begin{array}{c}\text { Buffalo River near } \\
\text { Dilworth }\end{array}$ & $1932-78$ & 24.4 & 8,922 & 8.6 \\
\hline
\end{tabular}


Table 6.--Comparison of surface-water quality at low and high flows [Chemical constituents are given in milligrams per liter]

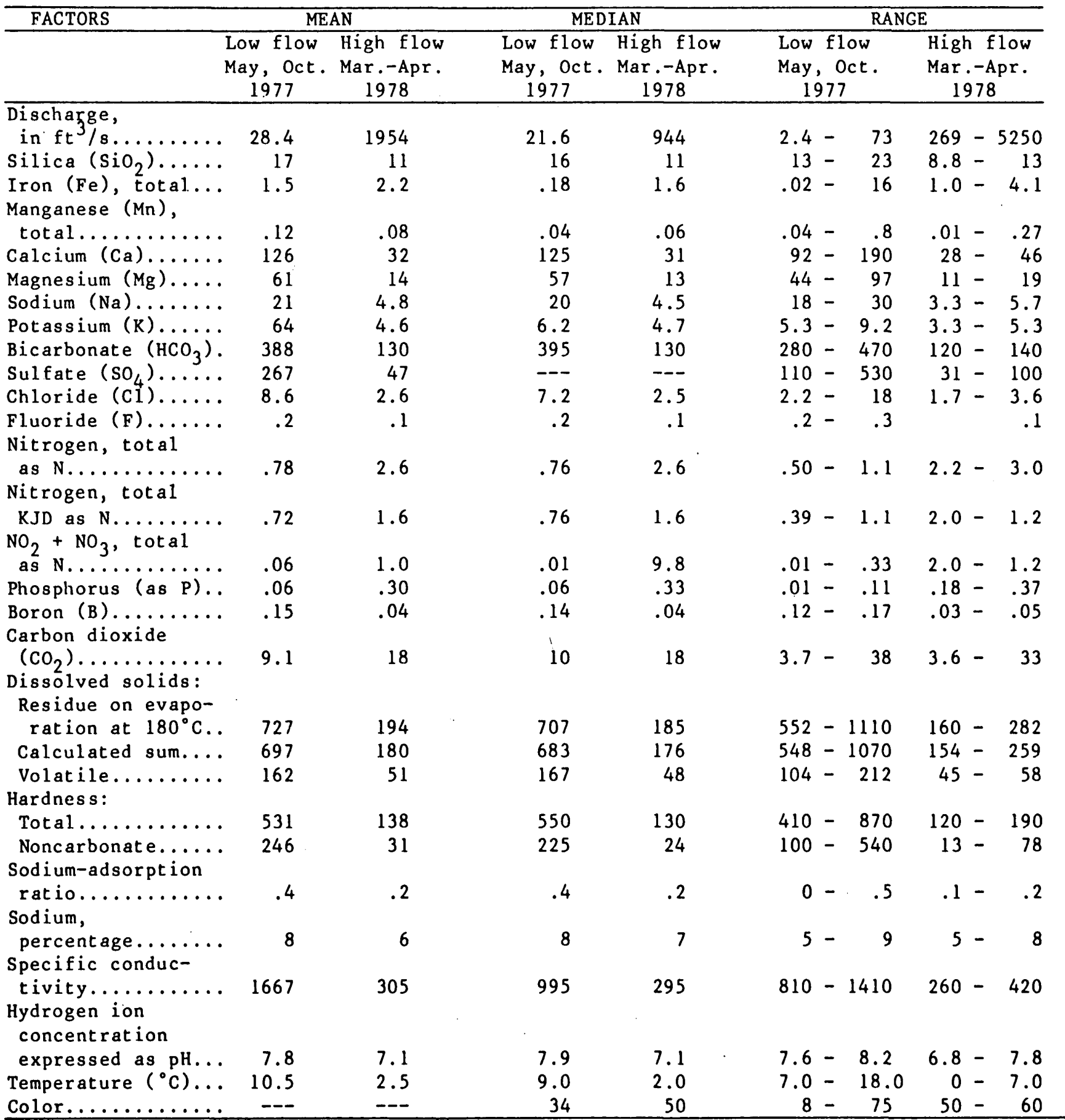


Assumptions made in the computation of average suspended-sediment discharge were that (1) the duration curves ( $f i g .35$ ) of water discharge for the 33-year period, 1946-78, are representative, and (2) the relationship of suspended-sediment discharge to water discharge shown in figure 26 is representative of the 33-year period, 1946-78. The validity of both assumptions would be affected by changes in vegetative cover, land use, climatic cycles, construction of small retention dams, agricultural drainage, and soil-conservation practices such as land forming, contouring, and terracing. The effect of the 1930's drought $c$ an be seen in table 5 by comparing the average sediment discharge of the Buffalo River near Dilworth during the 33-year base period (1946-78) with the average discharge computed for the 47-year period, 1932-78. Disregarding these possible changes, the computed average in table 5 may be used for estimating sediment discharges.

\section{Water Quality}

Surface water in the Buffalo River drainage system is dominantly a calcium bicarbonate type and is similar to ground water, especially at low flow in the upper reaches of the tributaries. The Buffalo River is generally lower in concentration of dissolved solids and of most individual ions than the South Branch Buffalo River. Sodium and chloride ions, however, are slightly higher in the Buffalo River than in the South Branch Buffalo River. At high flow there is a marked decrease in dissolved solids and in many of the individual ions. However, nutrients such as nitrogen and phosphorus show an increase with higher flow. A comparison of the mean, median, and range of various constituents of water taken at low and high flows at nine locations along the Buffalo River and South Branch Buffalo River is shown in table 6 . Locations of the surface-water sampling sites are shown in figure 39.

The relationship of specific conductance, streamflow, and precipitation during open water in 1977-78 for the Buffalo River draiuage gaging stations is shown in figures 28,29 , and 30 . Generally, the lowest annual specific conductance accompanies high runoff in spring. This was not the case in 1977 when spring runoff was relatively small.

The temperature of surface water follows seasonal and diurnal cycles in response to changes in air temperature. Thermographs show that the mean monthly temperature was lowest in January and highest in July (fig. 27). The total annual fluctuation was $23^{\circ} \mathrm{C}$. For July, the mean monthly temperature was $3{ }^{\circ} \mathrm{C}$ higher near Dilworth than near Hawley and $2{ }^{\circ} \mathrm{C}$ higher near Dilworth than at Sabin.

\section{SUMMARY}

Increasing demands for water have led to concern and conflicting opinions on water availability and quality near Moorhead. This study has shown that large water supplies for agricultural, industrial, and muncipal uses can be obtained in the western part of the Buffalo River watershed. 
Water supplies can be obtained at various depths from buried drift aquifers and possibly from Cretaceous rocks. The lower limit of the buried aquifers is the Precambrian surface, which ranges from 200 to 1,000 feet below land surface. Although some buried drift aquifer wells have high yields initially, recharge and storage may not be adequate to sustain the yields. The water quality is generally poor.

The Buffalo aquifer is the principal source of ground-water supplies in the area. It is a partly confined, elongate sand and gravel deposit that trends in a north-south direction 5 miles east of Moorhead. Wells in the aquifer yield water for the cities of Moorhead and Sabin, several irrigation systems, and many farms and houses. Test drilling revealed that the most permeable part of the Buffalo aquifer is in a deep, narrow trough down the center of the aquifer, which is 1 to 8 miles wide and 32 miles long. More than half the aquifer is overlain by lake sediments that range in thickness from 40 to 120 feet near the outer edges and from 0 to 20 feet in the middle. Saturated thickness ranges from 0 at the edges to as much as 200 feet in places along the axis. Average hydraulic conductivity varies from 20 feet per day along the outer edges to 300 feet per day in certain places.

Water flows generally northward within the aquifer from the watertable recharge area in the southern end. Water levels are mostly above the water level in the adjacent stream, indicating ground-water discharge to the stream. However, pumping from the Moorhead well field has reversed the normal head differences between aquifer and stream near the well field, thus inducing surface-water infiltration toward the well field. Base-flow measurements along the South Branch Buffalo River show that the river loses water to the aquifer near the Moorhead city well field and upstream of Sabin.

There is 270 billion gallons of water (estimated) stored in the Buffalo aquifer, based on its saturated thickness and porosity. However, the maximum theoretical amount of water that can be withdrawn regionally is approximately 120 billion gallons, assuming a specific yield of 0.2 and an even lowering of water levels to two-thirds of the saturated thickness. Well yields are greatest in the narrow, deep trough along the axis of the aquifer. Closely spaced (less than 500 feet) test drilling across the axis of the aquifer is required to locate the thickest permeable zone.

Although recharge is induced from the South Branch Buffalo River near Moorhead, the city well field may not be in the ideal place for maximum induced recharge. Additional test drilling and aquifer tests can locate the ideal place.

Artificial recharge may be feasible through ponds located near the center of the aquifer where it is most permeable and has a large amount of space for storage of water. Locations indicated by results of this study are along a line trending northwest-southeast through sec. 32 , sec. 29 , and sec. 19, T. 140 N., R. 47 W. 
The numercial-flow model used in this study indicated that a considerable amount of discharge takes place through the confining bed to either the adjacent stream or laterally as underflow to the west. The model also indicated the need for more data on (1) vertical hydraulic conductivity, head, and thickness of the confining bed; (2) head differences between aquifer, confining layers, and stream; and (3) longterm water levels, recharge, and pumpage.

Water from the Buffalo aquifer is a calcium bicarbonate type that is generally very hard. Dissolved-solids concentrations range from 300 to $1,900 \mathrm{mg} / \mathrm{L}$. Except for hardness, iron, and, in places, high sulfate concentrations, the water is suitable for municipal supplies. The water is suitable for irrigation because of low sodium hazard and concentrations of boron.

Water is available from the Red River of the North and from the Buffalo River and its tributaries. On the basis of records from 1945-78, average discharge at gaging stations near Hawley, near Dilworth, and at Sabin are $0.229,0.148$, and $0.108\left(\mathrm{ft}^{3} / \mathrm{s}\right) / \mathrm{mi}^{2}$, respectively. The duration curve for the South Branch Buffalo River at Sabin has a steep slope denoting highly variable streamflow. The curve for the Buffalo River near Hawley has a flatter slope at the lower end indicating a large quantity of basin storage or ground-water discharge to the stream. The low-flow frequency curves show a persistent low flow for the Buffalo River near Hawley and long periods of no flow or very low flow for the South Branch River at Sabin. About 90 percent of the high flows of streams in the Buffalo River watershed occur during March through July, with the greatest number in April. The average sediment yields for the Buffalo River near Hawley and near Dilworth and for the South Branch Buffalo River at Sabin are 4.2, 9.7, and 3.9 tons $/ \mathrm{mi}^{2}$ per year, respectively.

Surface water in the Buffalo River watershed is dominantly a calcium bicarbonate type similar to water in the Buffalo aquifer, especially at low flow in the upper reaches of the tributaries. Concentrations of dissolved solids and of most individual ions (except sodium and chloride) are generally lower in the Buffalo River than in the South Branch Buffalo River. The mean monthly temperature of the streams at the three gaging stations varies annually through a range of $23^{\circ} \mathrm{C}$. 


\section{REFERENCES}

Allison, I. S., 1932, The geology and water resources of north-western Minnesota: Minnesota Geological Survey Bulletin 22, 245 p.

Arndt, B. M., and Moran, S. R., 1974, Physical data for land-use planning, Cass County, North Dakota and Clay County, Minnesota: North Dakota Geological Survey Report of Investigation 54, $16 \mathrm{p}$.

Baker, D. G., and Kuehnast, E. L., 1978, Climate of Minnesota Part X, Precipitation normals for Minnesota: Minnesota Agricultural Experiment Station Technical Bulletin 314, $16 \mathrm{p}$.

Barr Engineering, Inc., 1975, Moorhead water supply study, Phase II: Report to the Public Service Commission, city of Moorhead, Minnesota, $60 \mathrm{p}$.

Bingham, J. W., 1960, Basic geologic and ground-water data for Clay County, Minnesota: Minnesota Division of Waters Bulletin 8, $138 \mathrm{p}$.

Byers, A. C., Wenze1, L. K., Laird, W. M., and Dennis, P. E., 1946, Ground water in the Fargo-Moorhead area, North Dakota and Minnesota: U.S. Geological Survey open-file report, $72 \mathrm{p}$.

Dennis, P. E., Akin, P.'D., and Worts, G. G., Jr., 1949, Geology and groundwater resources of parts of Cass and Clay Counties, North Dakota and Minnesota: North Dakota Ground-Water Studies, no. 11, Minnesota GroundWater Studies, no. $1,177 \mathrm{p}$.

Guyton and Associates, Inc., 1957, Report on ground-water conditions in the east Dilworth aquifer, Moorhead, Minnesota: Report to the city of Moorhead, Minnesota, 23 p.

Hall, C. M., and Willard, D. E., 1905, Description of Casselton and Fargo quadrangles, North Dakota-Minnesota: U.S. Geological Survey Atlas, Folio 117, p. 5 .

Helgesen, J. 0., 1977, Ground-water appraisal of the Pineland Sands area, central Minnesota: U.S. Geological Survey Water-Resources Investigation 77-102, 49 p.

Jacob, C. E., 1944, Notes on determining permeability by pumping tests under water-table conditions: U.S. Geological Survey open-file report, 25 p.

Leverett, Frank, 1932, Quaternary geology of Minnesota and parts of adjacent States: U.S. Geological Survey Professional Paper 161, 149 p.

Lohman, S. W., 1972, Ground-water hydraulics: U.S. Geological Survey Professional Paper 708, 70 p. 
Maclay, R. W., Bidwe11, L. E., and Winter, T. C., 1969, Water resources of the Buffalo River watershed, west-central Minnesota: U.S. Geological Survey Hydrologic Investigations At las HA-307.

Maclay, R. W., and Winter, T. C., 1967, Geochemistry and ground-water movement in northwestern Minnesota: Ground Water, v. 5, no. 1, p. 11-19.

Maclay, R. W., Winter, T. C., and Bidwe11, L. E., 1972, Water resources of the Red River of the North drainage basin in Minnesota: U.S. Geological Survey Water-Resources Investigations 72-1, 129 p.

Meyer, A. F., 1955, Report to city of Moorhead, Minnesota on well water supply: Minneapolis, Moorhead, Minnesota, $12 \mathrm{p}$.

National Oceanographic and Atmospheric Administration (NOAA), 1977, Climatological data, annual summary, 1976: v. 82, no. 13, 14 p. 1978, Climatological data, annual summary, 1977: v. 83, no. 13, 14 p. 1979, Climatological data, annual summary, 1978: v. 84, no. 13, 14 p.

Nikiforoff; C. C., and others, 1939, Soil survey (reconnaissance) of the Red River Valley area, Minnesota: U.S. Department of Agriculture ser. 1933, no. 25,98 p.

Pinder, G. E., and Bredehoeft, J. D., 1968, Application of the digital computer for aquifer evaluation: Water-Resources Research, v. 4, no. 5, p. 1069-1073.

Prickett, T. A., 1965, Type-curve solution to aquifer tests under watertable conditions: Ground Water, v. 3, no. 3 .

Rodis, H. G., 1961, Use of water-well data in interpreting occurrence of aquifers in northeastern Lyon County, Minnesota: Geological Society of America Bulletin, v. 72, no. 8, p. 1275-1278.

Sims, P. K., 1970, Geologic map of Minnesota: Minnesota Geological Survey Miscellaneous Map Series, Map M-14.

Theis, C. V., 1935, The relation between the lowering of the piezometric surface and the rate and duration of discharge of a well using groundwater storage: Transactions of the American Geophysical Union, v. 16, pt. 2, p. 519-524.

Trescott, P. D., Pinder, G. F., and Larson, S. P., 1976, Finite-difference model for aquifer simulation in two dimensions with results of numerical experiments: U.S. Geological Survey Techniques Water-Resources Investigations, Book 7, Chapter C1, 116 p. 
U.S. Geological Survey, 1978, Water resources data for Minnesota, water year 1977: U.S. Geological Survey Water-Data Report MN-77-1, 285 p.

1979, Water resources data for Minnesota, water year 1978: U.S. Geological Survey Water-Data Report MN-78-1, 300 p.

U.S. Salinity Laboratory Staff, 1954, Diagnosis and improvement of saline and alkali soils: U.S. Department Agriculture, Handbook 60, 160 p.

Upham, Warren, 1895, The Glacial Lake Agassiz: U.S. Geological Survey Monograph 25, 658 p.

Winche11, N. H., Grant, U. S., Todd, J. E., Upham, Warren, and Winchell, H. V., 1899, The geology of Minnesota: Minnesota Geological Natural History Survey Final Report, v. 4, 616 p.

Winchel1, N. H., and Upham, Warren, 1888, The geology of Minnesota:

Minnesota Geological Natural History Survey Final Report, v. 2, 695 p.

Winter, T. C., 1967, Linear sand and gravel deposits in the sub-surface of Glacial Lake Agassiz, in Mayer-Oakes, W. J., ed., Life, land and water--proceedings of the 1966 conference on environmental studies of the Glacial Lake Agassiz region: Winnipeg, University of Manitoba Press, p. 141-154.

Wright, H. E., Jr., 1962, Role of the Wadena lobe in the Wisconsin glaciation of Minnesota: Geological Society of America Bulletin, v. 73, p. 73-100.

Wright, H. E., Jr., and Ruhe, R. V., 1965, Glaciation of Minnesota and Iowa, in Wright, H. E., Jr., and Frey, D. G., eds, The Quaternary of the United States: Princton, N. J., Princeton University Press, p. 29-41.

Zohdy, A. A. R., and Bisdorf, R. J., 1979, Geoelectrical investigation with Schlumberger soundings of the Buffalo River aquifer near Moorhead, Minnesota: U.S. Geological Survey Open-File Report 79-299, 243 p. 